\title{
Desafios para implementar a integralidade da assistência à saúde no SUS: estudo de caso no município de São Paulo (SP)
}

Sandra Maria Spedo

Tese apresentada ao Programa de PósGraduação em Saúde Pública da Faculdade de Saúde Pública da Universidade de São Paulo para obtenção do título de Doutor em Saúde Pública

Área de concentração: Serviços de Saúde Pública

Orientador: Prof. Dr. Oswaldo Yoshimi Tanaka

São Paulo

2009 
É expressamente proibida a comercialização deste documento, tanto na forma impressa como eletrônica. Sua reprodução total ou parcial é permitida exclusivamente para fins acadêmicos e científicos, desde que na reprodução figure a identificação do autor, título, instituição e ano da tese. 


\section{AGRADECIMENTOS}

A todos aqueles que têm participado do movimento social da região sudeste, cuja luta cotidiana para garantir seu direito à saúde, além de exemplo, representou um importante estímulo para o desenvolvimento desta pesquisa...

Ao professor Oswaldo Yoshimi Tanaka, um orientador especial. Sempre disponível, com muitas contribuições, provocações, e apoio. Grande aprendizado... Feliz descoberta...

Ao Nica, com quem tenho compartilhado todos os momentos, inclusive esta pesquisa, o que tornou este processo um pouco mais suave. Seu companheirismo, amor e carinho foram fundamentais para eu que chegasse até aqui...

A Wanda, amiga e grande companheira de trabalho há muitos anos. Pela solidariedade e apoio constante nessa trajetória...

Aos 'gestores do SUS' em São Paulo aqui denominados 'informantes-chaves' que, apesar das resistências institucionais, aceitaram prontamente participar da pesquisa... Aos trabalhadores da Coordenadoria Regional Sudeste, da Supervisão Técnica de Saúde do Ipiranga que disponibilizaram documentos, informações, conversas.... E, à equipe da UBS Jd. Secker que disponibilizou informações e apoiou a realização do grupo focal...

Aos assistentes de pesquisa Alexandre F. Watanabe e Maíra S. Pinto pelas competentes transcrições; a Cristiane Locatelli pela coordenação do grupo focal...

A equipe da secretaria do Departamento de Práticas de Saúde Pública e Comissão de Pós Graduação da FSP-USP sempre disponível e solidária...

A equipe da secretaria do Departamento de Medicina Preventiva pelo apoio material e afetivo. Pelos cafés com muito afeto da Odete...

Aos professores que participaram da pré-banca, Cristina Melo, Luiz Cecílo, Edson Tamaki e Claúdio Gastão de Castro, pelas críticas e sugestões que muito contribuíram para a finalização deste trabalho...

A minha mãe, Norma, por toda determinação, garra e empenho para que eu pudesse chegar até aqui...

Aos meus grandes amores, Dani e Gabi, por tudo... 
"Na relação entre sujeito e objeto, neutralidade é a perspectiva do sujeito, enquanto objetividade é a do objeto. No processo de conhecimento ambas se correspondem [...]. Significam, de todos os modos, a possibilidade de refletir a realidade assim como ela é. [...] A neutralidade é uma postura farsante, por ingenuidade, ou por esperteza. [...] Neutralidade é truque, é golpe do cientista que pretende viver tranquilamente à sombra do poder, sem 'dor de consciência'. Escamoteia sua condição histórica de ator político, numa sociedade pobre de recursos e de saber especializado. [...] $O$ serviço instrumental subserviente da ciência é seu pior engajamento, sobretudo para uma atividade que se apregoa superior ao senso comum, capaz de avaliar tudo, sempre crítica e impiedosa contra os percalços da lógica e da forma” Pedro Demo ${ }^{1}$ (1995, p. 82-4).

\footnotetext{
${ }^{1}$ DEMO, P. Neutralidade científica. In: . Metodologia científica em ciências sociais. $3^{\mathrm{a}}$ ed. rev. e ampl. São Paulo: Editora Atlas; 1995. p. 70-85.
} 


\section{RESUMO}

Introdução. O Sistema Único de Saúde (SUS) apresentou avanços significativos durante as duas décadas de sua existência. Contudo, a integralidade se destaca como o princípio que, ainda, não foi efetivamente incorporado na organização dos serviços e no cotidiano da atenção. Para realização desta pesquisa, e considerando a polissemia do termo, definiu-se um conceito operacional de integralidade, circunscrito a um de seus múltiplos sentidos, relacionado ao modo de organizar os serviços de saúde. Assim, denominou-se integralidade da assistência à dimensão relacionada com a continuidade do cuidado em saúde, garantida pelo acesso a serviços que incorporam distintas densidades tecnológicas, distribuídos em todos os níveis de complexidade do sistema de saúde. Objetivo. Avaliar a incorporação do princípio da integralidade na gestão e organização dos serviços de saúde em um território selecionado do município de São Paulo, SP. Métodos. A pesquisa foi desenvolvida utilizando a estratégia metodológica do estudo de caso, a partir das seguintes fontes de evidência: (a) documentos de gestão (leis, decretos, portarias, planos, normas técnicas, relatórios de gestão, atas de reunião); b) entrevistas nãoestruturadas com informantes-chaves selecionados entre os gestores do SUS no município; c) grupo focal com usuários de uma Unidade Básica de Saúde do território selecionado; d) observação participante, desenvolvida em serviços de saúde e instâncias político-administrativas da Secretaria Municipal de Saúde (SMS-SP). Utilizou-se a técnica da análise temática para analisar o material coletado. Os temas destacados foram: descentralização da gestão municipal; regionalização intramunicipal; e, acesso a ações e serviços de média complexidade. Resultados. Os resultados são apresentados na forma de três artigos, sendo cada um deles correspondente a um dos temas destacados. Os artigos elaborados são: (1) O desafio da descentralização do Sistema Único de Saúde (SUS) em município de grande porte: o caso de São Paulo (SP), Brasil; (2) A regionalização intramunicipal do Sistema Único de Saúde (SUS): um estudo de caso do município de São Paulo (SP), Brasil; e (3) O difícil acesso a serviços de média complexidade do SUS na maior metrópole brasileira, São Paulo (SP), Brasil. Considerações finais. Constatou-se que a política de saúde implementada pela SMS-SP contribuiu para manter e aprofundar a fragmentação do sistema de saúde no município de São Paulo. As estruturas existentes e os mecanismos utilizados pela gestão municipal não tem contribuído para efetivar a integralidade da assistência. O SUS em São Paulo continua distante da "imagem objetivo" de um sistema de saúde que incorpore o princípio da integralidade como um de seus eixos estruturantes.

Palavras-chave: integralidade; gestão em saúde; regionalização; política de saúde; sistemas locais de saúde; Sistema Único de Saúde 


\section{ABSTRACT}

Introduction: The Single Health System (Sistema Único de Saúde - SUS) presented expressive development during the two decades of its existence. Nevertheless, the issue, which has not been incorporated in the services organization and in the daily basis of the attention, is the global approach. In order to carry out this research and considering the polysemantic word, an operational concept of integrality has been defined, limited to one of its meanings and related so as to organize the health services. Therefore, it has been established the integrality of the health care to the scope related to the permanence of health care, guaranteed by the access to the services, which comprise several levels of technology along all levels of complexity of the health system. Objective: To evaluate the incorporation of the principle of the integrality in the management and organization of health services in a specific area of the city of São Paulo. Methods: The research was performed by utilizing the methodological strategy of case study derived from the following sources of data: (a) management papers (laws, decrees, plans, technical specifications, management reports, minutes of meetings); (b) non-structured interviews with key informers selected among the SUS managers of the city; (c) focal group with users of a Basic Unit of Health of the selected area; (d) active observation, developed in health services and political administrative areas of the City Health Department (SMS-SP). The subject analysis technique has been used for the gathering of the data. The selected subjects were: (1) the decentralization of city management; intercity regionalization, and access to actions and services of medium complexity. Results: Results are presented in the form of 3 articles, being each one related to the selected subjects described. The articles are: (1) The challenge of the decentralization of the Single Health System (SUS in a large city: the instance of the City of São Paulo (SP), Brazil; (2) The intercity regionalization of the Single Health System (SUS): a case study of the City of São Paulo (SP), Brazil; and (3) The complex access to services of medium complexity of SUS in the largest Brazilian metropolis. Final considerations: It has been verified that the Health System applied by the SMS-SP has been a factor to maintain and intensified the fragmentation of the Health System in the City of São Paulo. The present structures and mechanisms used by the City administration have not played the part to produce the integrality of the health care. The SUS in São Paulo is still far from the "objective image" of a health care system that comprises the principle of global approach as one of its structuring axis.

Key words: integrality; health management; regional health planning; health policy local health systems; Single Health System 
IINDICE 


\section{ÍNDICE}

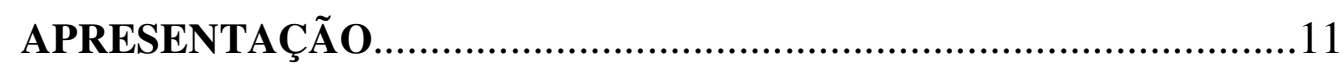

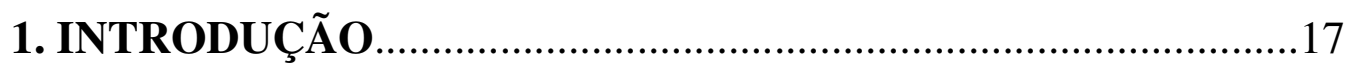

1.1. UMA PROXIMAÇÃO AO CONCEITO DE INTEGRALIDADE ..............................19

1.2. POR QUE ESTUDAR A INTEGRALIDADE DA ASSISTÊNCIA À SAÚDE?

1.3. POR QUE ESTUDAR A INTEGRALIDADE EM UM MUNICÍPIO DE GRANDE

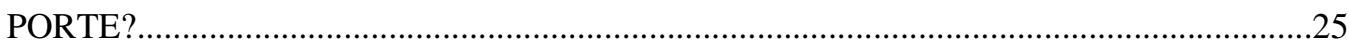

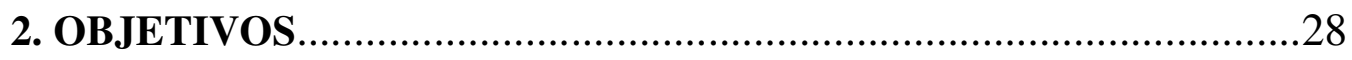

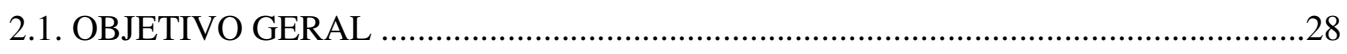

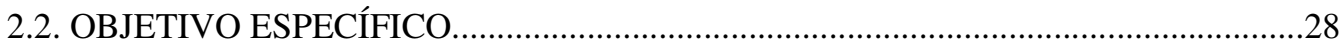

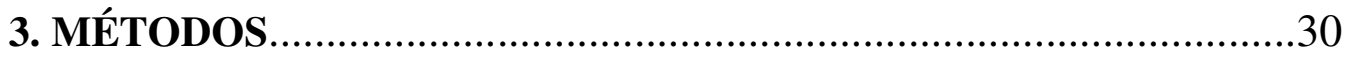

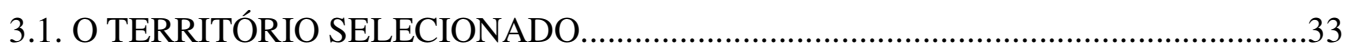

3.2. VARIÁVEIS PARA AVALIAR INTEGRALIDADE........................................... 38

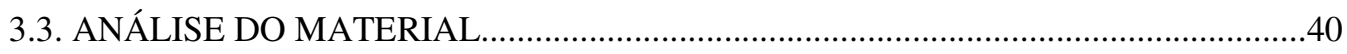

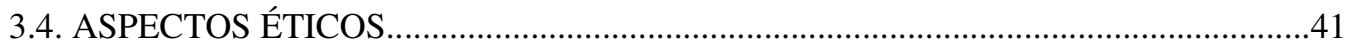

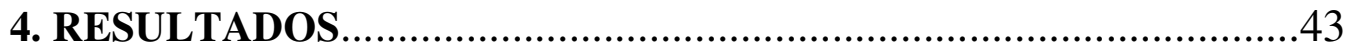

4.1. O DESAFIO DA DESCENTRALIZAÇÃO DO SISTEMA ÚNICO DE SAÚDE (SUS)

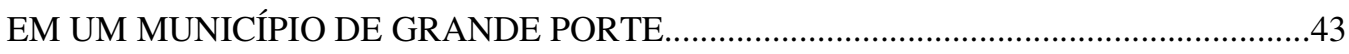

4.2. A REGIONALIZAÇÃO INTRAMUNICIPAL DO SISTEMA ÚNICO DE SAÚDE (SUS): UM ESTUDO DE CASO DO MUNICÍPIO DE SÃO

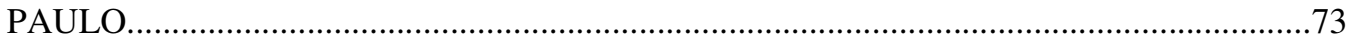


4.3. O DIFÍCIL ACESSO A SERVIÇOS DE MÉDIA COMPLEXIDADE DO SUS NA MAIOR METRÓPOLE BRASILEIRA, SÃO PAULO (SP), BRASIL ................................105

5. CONSIDERAÇÕES FINAIS.................................................. 139

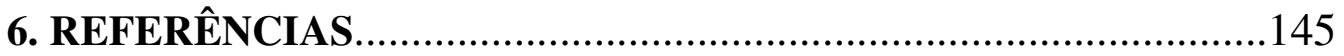


APRESENTACÃO 


\section{APRESENTAÇÃO}

A escolha do objeto desta pesquisa está associada a trajetória e inserção da autora, na condição de médica sanitarista, junto ao sistema de saúde do município de São Paulo. Minha aproximação a essa realidade começou no início da década de 1980, no contexto da Reforma Sanitária, como residente de Medicina Preventiva e Social, Desde então, mantive um vínculo institucional com os serviços, - Secretaria de Estado da Saúde e Secretaria Municipal de Saúde - e outro com a universidade, com atuação muito vinculada à região sudeste do município. Essa 'dupla militância', apesar de alguns desgastes, sempre foi rica, na medida em que possibilitava articular as atividades de ensino, pesquisa e extensão, desenvolvidas junto à universidade, com a prática de médica sanitarista, em serviços de saúde. Nesse caminho, assumi diferentes papéis e tive a oportunidade de conviver com distintos atores sociais, militantes do SUS, que contribuíram muito para minha formação. Nessa condição, pude me envolver ativamente no projeto de construção do SUS no município de São Paulo e, posteriormente, convivi de perto com seu desmanche, no período em que o PAS foi implantado. Esses momentos foram muito intensos e, a partir de então, aumentaram as inquietações e foi se tornando mais viva a necessidade de buscar compreender essa realidade a partir de outro ângulo, com o apoio dos métodos científicos. Afinal, acredito firmemente no SUS, defendo seus princípios e era difícil aceitar passivamente o ‘caos’ do sistema de saúde da maior cidade brasileira.

Durante todo esse período, uma questão sempre muito presente era a dificuldade de integração entre os serviços. Trabalhei muito tempo em uma Unidade Básica de 
Saúde, responsável por parte do território da maior favela paulista que, apesar de ter grande hospital público praticamente ao lado, não conseguia encaminhar seus usuários para o mesmo. E, mesmo com a mobilização do movimento social da região, bastante organizado, a situação permanecia inalterada.

Assim, era praticamente natural que o tema da integralidade se destacasse como central para a realização desta pesquisa. Inicialmente, articulando as propostas de dois doutorandos, foi elaborado um projeto conjunto intitulado: "O processo de (re)construção do Sistema Único de Saúde no município de São Paulo. Uma avaliação sobre a incorporação do princípio da integralidade na política municipal de saúde", visando solicitar financiamento junto à Fapesp, o que facilitaria o desenvolvimento da pesquisa.

A tese aqui apresentada é parte desse projeto e teve como objetivo central avaliar a incorporação da integralidade na gestão e organização dos serviços de saúde em um território do município de São Paulo, entre 2005-2008, período correspondente a uma administração municipal.

No capítulo introdutório, buscamos justificar a importância de estudar o tema da integralidade que vem sendo apontado, por diversos pesquisadores e gestores, como um dos princípios que menos avançou nesses vinte anos de implementação do SUS. Dado o caráter polissêmico do termo, destacamos alguns de seus múltiplos sentidos e apresentamos um conceito operacional que serviu como referência para a realização desta pesquisa. Escolhemos trabalhar com a integralidade da assistência entendida como a continuidade do cuidado em saúde garantida pelo acesso a serviços que 
incorporam distintas densidades tecnológicas, classificados como de distintos níveis de complexidade do sistema de saúde.

A análise dos dados e informações coletadas em entrevistas com gestores do SUS no município, documentos, observação participante e grupo focal com usuários, permitiu destacar três temas centrais que possibilitaram a elaboração de artigos, seguindo as orientações do corpo editorial dos periódicos da área. Nesse sentido, os temas eleitos foram: a) descentralização da gestão municipal, enquanto dimensão político-administrativa com potencial para favorecer a governabilidade do gestor locorregional; b) regionalização intramunicipal, como estratégia para organizar os serviços em um sistema local de saúde visando facilitar a efetivação da integralidade da atenção; e c) acesso a ações e serviços de média complexidade, cuja garantia é condição para a integralidade.

O primeiro artigo intitulado “O desafio da descentralização do Sistema Único de Saúde (SUS) em município de grande porte: o caso de São Paulo (SP), Brasil" analisou o processo de descentralização/centralização do SUS no município de São Paulo. No início da gestão estudada foi implementada uma reestruturação políticoadministrativa da Secretaria Municipal de Saúde (SMS-SP), com forte caráter racionalizador e centralizador. Essa medida resultou no esvaziamento técnico e político das estruturas locorregionais da SMS-SP. Com isso, observou-se que a limitada capacidade de governo e baixa governabilidade do gestor do SUS no nível locorregional comprometiam a coordenação e desenvolvimento de ações que visem à incorporação do princípio da integralidade. Considerando a dimensão e complexidade do município de São Paulo, discutiu-se sobre a necessidade de retomar 
o processo de descentralização na saúde, articulado à descentralização do governo municipal, visando democratizar a gestão e favorecer a implementação dos princípios do SUS.

O segundo artigo, “A regionalização intramunicipal do Sistema Único de Saúde (SUS): um estudo de caso do município de São Paulo (SP), Brasil”, incorporou a avaliação do processo de implementação de um projeto de organização de regiões no município de São Paulo. Essa proposta foi destacada nas entrevistas de vários gestores, como sendo uma importante estratégia para organizar sistemas regionais mais funcionais, visando à integralidade da atenção. Esse projeto foi idealizado e apresentado, no início da gestão, porém não foi efetivamente implementado. Por um lado, o insucesso do projeto foi associado à política implementada pela SMS-SP que manteve estruturas político-administrativas independentes para a gestão da atenção básica e da assistência hospitalar. E, ainda, não assumiu a gestão de ambulatórios e hospitais estaduais localizados no município. Por outro, discutiu-se o papel desempenhado pelos hospitais nesse processo, destacando-se o poder institucional dos mesmos e sua resistência em se integrar ao sistema de saúde.

No terceiro artigo, intitulado “ $O$ difícil acesso a serviços de média complexidade do SUS na maior metrópole brasileira, São Paulo (SP), Brasil” visava avaliar mecanismos utilizados pela gestão do SUS, no município de São Paulo, para garantir acesso à assistência de média complexidade. A média complexidade foi identificada, pelos gestores, como o "gargalo" do SUS e um dos principais obstáculos para a construção da integralidade. Buscou-se descrever os caminhos percorridos pelos usuários para acessar os serviços da média complexidade, a partir da visão dos 
gestores e dos próprios usuários, utilizando-se para tal os dados obtidos nas entrevistas com os gestores, no grupo focal com usuários e a observação participante. A estratégia utilizada pela SMS-SP para enfrentar essa situação foi centrada na informatização dos serviços, que não foi acompanhada de outras ações fundamentais como mudanças organizacionais e reorganização dos processos de trabalho, em todos os níveis de atenção. Observou-se que a incorporação dessa tecnologia teve pouco impacto na melhoria do acesso, o que foi confirmado pelo relato dos usuários. 
INTRODUCCÃO 


\section{INTRODUÇÃO}

O Sistema Único de Saúde (SUS), 20 anos após sua institucionalização, continua sendo um projeto em construção, enfrentando constantes desafios para sua implementação. Desde a promulgação da Constituição Federal de 1988, importantes avanços foram conquistados na direção da materialização do projeto da Reforma Sanitária Brasileira de criação de um sistema de saúde universal. A incorporação do direito à saúde na legislação, a participação e o controle social, a descentralização da gestão, a ampliação do acesso e a extensão da cobertura de serviços são consideradas importantes avanços do SUS (LEVCOVITZ e col., 2001; CNS, 2002; VIANA e col., 2002, OLIVEIRA, 2003; BARATA e col., 2004).

No entanto, é importante destacar que, na última década, esses avanços ocorreram sob uma conjuntura em que a política econômica adotada não privilegiou as políticas sociais. Assim, houve uma diminuição dos investimentos nas áreas sociais, acompanhada do agravamento da desigualdade e exclusão social. O SUS, recém criado, encontrou um terreno bastante desfavorável para sua efetivação. Para LEVCOVITZ e col. (2001, p. 270), a agenda da reforma sanitária brasileira foi:

"construída na contra-corrente das tendências hegemônicas de reforma dos Estados nos anos 80, e sua implementação nos anos 90 se dá em uma conjuntura bastante adversa. Face ao novo cenário político nacional, a construção do SUS expressa essas tensões, sendo observados tantos avanços como dificuldades nos diversos âmbitos estratégicos para a implantação do SUS".

O avanço do neoliberalismo no Brasil, desde o final dos anos 1980, com a adesão às recomendações do FMI e Banco Mundial, repercutiu diretamente na política de 
saúde. Os relatórios de avaliação e as propostas do Banco Mundial para o setor saúde eram, inclusive, antagônicos à proposta do SUS. MATTOS (2001) considerou que havia um "evidente o contraste entre a posição brasileira e a posição defendida, por exemplo, pelo Banco Mundial”. Entretanto, mesmo apresentando divergências, essas propostas compartilhavam "algumas diretrizes comuns: a defesa da descentralização e da participação popular. O que nos leva a pensar que muitas das suas diferenças girem em torno da adesão ou não ao princípio da integralidade” (MATTOS, 2001, p. 40.).

Apesar dos avanços significativos na implementação do SUS e da existência de experiências localizadas que contemplam a integralidade em suas práticas, esse se destaca como sendo um princípio que não foi efetivamente incorporado na organização do sistema e no cotidiano da atenção. (GIOVANELLA e col., 2002; MATTOS, 2004).

Esse tema assumiu nova dimensão nesta década, a partir do debate sobre a necessidade de avançar no processo de descentralização e regionalização do SUS e superar os obstáculos ainda presentes para a efetivação dos princípios da integralidade e eqüidade do SUS. O Ministério da Saúde incorporou em sua pauta a discussão dos gestores estaduais e municipais e assumiu a condução do processo de construção de um novo instrumento de gestão para o SUS, com potencial de contribuir para a consolidação desses princípios (SILVA e DOBASHI, 2006). Assim, foi elaborado e editado o Pacto pela Saúde (BRASIL, 2006), que apresenta a diretriz da regionalização como eixo estruturante do pacto de gestão, no sentido de viabilizar a integralidade da atenção. 


\subsection{UMA APROXIMAÇÃO AO CONCEITO DE INTEGRALIDADE}

A integralidade constitui um dos princípios finalísticos do SUS. A Constituição Federal, no artigo 198 estabelece que as ações e serviços de saúde devam ser organizados de acordo com algumas diretrizes, dentre as quais o atendimento integral (BRASIL, 1988). E, a Lei Orgânica da Saúde (Lei no 8.080), em seu capítulo II estabelece que:

Art. $7^{o}$ As ações e serviços públicos de saúde e os serviços privados contratados ou conveniados que integram o Sistema Único de Saúde (SUS), são desenvolvidos de acordo com as diretrizes previstas no art. 198 da Constituição Federal, obedecendo ainda aos seguintes princípios:

(...)

II - integralidade da assistência, entendida como conjunto articulado e contínuo das ações e serviços preventivos e curativos, individuais e coletivos, exigidos para cada caso em todos os níveis de complexidade do sistema. (BRASIl, 1990).

Dado o significado do termo integralidade, a dimensão que esse princípio pode assumir na organização das ações e serviços é bastante ampla e complexa. Assim, apesar de um núcleo comum, observam-se diferenças entre as abordagens de distintos autores sobre esse tema.

KEHRIG (2001), em sua revisão, situa os antecedentes da integralidade em saúde na própria discussão dos modelos de organização das práticas em saúde. A integralidade está incorporada no movimento histórico das concepções do processo saúde-doença e na concepção integral da saúde. Segundo a autora, a noção de integralidade já estava presente no ideário da "polícia médica" alemã que propunha a organização de um “sistema de uma política médica integral". No século XX, essa idéia assumiu novas 
dimensões nos projetos da Medicina Integral, da Medicina Preventiva e da Medicina Comunitária.

Buscando uma síntese, a autora destaca cinco dimensões conceituais de integralidade: a apreensão do coletivo enquanto objeto de trabalho das práticas de saúde; concepção da abordagem da totalidade biopsicossocial do indivíduo; a integração sanitária, através da organização de ações articuladas de prevenção e cura, voltadas aos indivíduos e coletivos; a apreensão do conjunto de problemas de saúde da população; e o compromisso com a intervenção sobre os determinantes dos processos de saúde e doença.

"A integralidade em saúde compreende a atenção integral à saúde das pessoas em seu habitat, um território-processo, de forma articulada com uma ação integral sobre os problemas de saúde e suas causas. A ampliação da concepção não diminui a concepção do cuidado curativo individual, as dimensões apresentadas são acumulativas, coletiva e individual, de prevenção e cura, ou seja, proteção e recuperação da saúde, implicando na apreensão e atuação sobre os vários momentos dos processos de saúde e doença”. (KERHIG, 2001, p. 156).

No Brasil, a integralidade da atenção, enquanto diretriz política para organizar serviços e o sistema de saúde, ganhou relevância a partir do movimento da Reforma Sanitária. De acordo com PAIM (2006), essa diretriz política foi contemplada nas bases conceituais do projeto da Reforma em distintas perspectivas: como integração das ações de promoção, proteção, recuperação e reabilitação; como forma de atuação profissional; como garantia da continuidade da atenção nos distintos níveis de complexidade do sistema; e, como articulação de distintas políticas sociais. 
MENDES (1993, p. 149) apresenta a integralidade como um dos princípios organizativo-assistenciais do Distrito Sanitário, considerando que sua aplicação, respeitando e adaptando-se às singularidades de cada território.

“(...) implica reconhecer a unicidade institucional dos serviços de saúde para $o$ conjunto de ações promocionais, preventivas, curativas e reabilitadoras $e$ que as intervenções de um sistema de saúde sobre o processo saúde-doença conforma uma totalidade que engloba os sujeitos do sistema e suas interrelações com os ambientes natural e social”.

Nos últimos anos, alguns pesquisadores vêm buscando aprofundar a reflexão sobre a integralidade no SUS. Dentre eles destaca-se PINHEIRO (2001, p. 65) que, considerando o caráter polissêmico do termo, assume integralidade como sendo

“(...) uma ação social resultante da permanente interação dos atores na relação demanda e oferta, em planos distintos de atenção à saúde (plano individual - onde se constroem a integralidade no ato da atenção individual e o plano sistêmico - onde se garante a integralidade das ações na rede de serviços), nos quais os aspectos objetivos e subjetivos sejam considerados".

CECÍLIO (2001) discutindo sobre a importância de se identificar e trabalhar a integralidade, no âmbito do planejamento e da organização das práticas e serviços de saúde assume, para tanto, duas dimensões, denominando-as de "integralidade focalizada" e "integralidade ampliada". A primeira se dá no espaço singular de cada serviço de saúde, através do esforço da equipe de saúde de traduzir a atender às necessidades de saúde de uma dada população. A segunda (integralidade pensada no "macro") é fruto da articulação de cada serviço a uma rede mais complexa, composta por outros serviços e instituições, incluindo outros setores além da saúde.

MATTOS (2001; 2005) traz, ainda, algumas reflexões importantes sobre a integralidade, enfatizando os usos, os sentidos do termo, sem buscar uma definição 
para a mesma. Para esse autor, a integralidade, mais do que um princípio do SUS, é uma "bandeira de luta", uma "imagem objetivo". Destaca três sentidos de integralidade: a) como traço de boas práticas de saúde; b) como modo de organizar os serviços de saúde; e c) como orientador de políticas de saúde ou de respostas governamentais a certos problemas de saúde. Subjacente a esses sentidos está o princípio do direito universal de atendimento das necessidades de saúde.

\subsection{POR QUE ESTUDAR A INTEGRALIDADE DA ASSISTÊNCIA À} SAÚDE?

O processo de descentralização da saúde no Brasil contribuiu para ampliar o acesso aos serviços de saúde, particularmente na atenção básica. Contudo, é importante considerar que a descentralização per se é insuficiente para a concretização dos demais princípios de SUS (LEVCOVITZ e col., 2001). Assim, apesar de se constituírem em condições necessárias, tanto a descentralização da gestão quanto a ampliação do acesso, não são suficientes para a efetivação da integralidade da atenção.

Saliente-se, ainda, que a operacionalização do princípio da integralidade da atenção está condicionada a ações e intervenções de naturezas distintas em todos os níveis do sistema de saúde e, ainda, em outros setores. No campo da política de saúde, a integralidade deve ser assumida enquanto eixo norteador da reorientação do modelo assistencial, envolvendo ações intra e intersetoriais. Na gestão do sistema, é 
necessário garantir o acesso à atenção em todos os níveis de complexidade do sistema assegurando a integração organizacional e programática da assistência individual com as ações de caráter coletivo. No âmbito da organização dos serviços, a integralidade deve ser assumida enquanto compromisso de cada profissional e das equipes de saúde no sentido de atender às necessidades de saúde dos cidadãos, individual e coletivamente.

Na última década, o tema da integralidade ganhou relevância e centralidade tanto na pauta dos gestores do SUS, quanto em pesquisas acadêmicas. Cabe destacar o papel desempenhado pelo Laboratório de Pesquisas sobre Práticas de Integralidade em Saúde (LAPPIS), vinculado ao Instituto de Medicina Social da Universidade Estadual do Rio de Janeiro, que contribuiu para estimular a produção científica nessa temática. Nesse processo, destacam-se a discussão de caráter teórico-conceitual, bem como o desenvolvimento de projetos tanto para implantação quanto avaliação de projetos visando à incorporação da integralidade nas práticas em saúde.

A partir de levantamentos realizados nas bases de dados LILACS, MEDLINE e bancos de teses (DEDALUS, CAPES, THESIS) pode-se constatar uma importante produção científica cujo núcleo temático central foi integralidade. Observa-se grande diversidade na abordagem desse tema, coerente com a polissemia do termo. A maioria dos trabalhos aborda a integralidade no âmbito da atenção básica (CARVALHO, 1991; SÁ, 2003; SERRA, 2003; SILVA, 2006; PIRES, 2007; FAVORETO 2007; CAMARGO JÚNIOR e col., 2008). Outros se referem a programas específicos, particularmente saúde da mulher, saúde bucal, saúde mental e AIDS (LOPES, 1996; OLIVEIRA, 2000; MAEDA, 2002; HONORATO, 2007; 
LOPES, 2007). E, em menor número, encontram-se aqueles que abordam a incorporação da integralidade na organização de sistemas de saúde, analisando distintas dimensões (FURTADO, 1993; KEHRIG, 2001; FERREIRA, 2003; SAITO, 2004; SILVA, 2003; SILVA, 2004).

Nota-se, ainda, uma produção crescente, nos últimos anos, discutindo e avaliando a incorporação da integralidade enquanto eixo orientador da formação de profissionais de saúde (CECCIM e FEUERWERKER, 2004; MATTOS, 2006; MACHADO e col., 2007; SILVA, 2008).

Nesse contexto, julgou-se importante e oportuna a realização deste estudo, abordando a integralidade em sua dimensão ampliada, aspecto ainda pouco estudado. Compartilhamos com a preocupação expressa por CECÍlLIO (2001, p. 118) de que "precisamos deslocar nosso foco de atenção da 'atenção primária' como lugar privilegiado da integralidade. Aliás, integralidade não se realiza nunca em um serviço: integralidade é objeto de rede”.

PINHEIRO e col. (2007), dialogando com o autor acima, defendem que o acesso da população a todos os níveis de atenção do sistema de saúde seria condição e o ponto de partida para a construção do princípio da integralidade.

Em que pesem a polissemia do termo e a interdependência de ações para a efetivação do princípio da integralidade da atenção no SUS, assumiu-se, neste estudo, um conceito operacional de integralidade, circunscrito a um de seus múltiplos sentidos, relacionado ao modo de organizar os serviços de saúde. Para tanto, elegemos trabalhar com a integralidade da assistência como a continuidade do cuidado em 
saúde garantida pelo acesso a serviços que incorporam distintas densidades tecnológicas, classificados como de distintos níveis de complexidade do sistema de saúde.

\subsection{POR QUE ESTUDAR A INTEGRALIDADE EM UM MUNICÍPIO DE GRANDE PORTE?}

Ao propor uma pesquisa abordando a integralidade a partir da concepção proposta, consideramos que o campo privilegiado para a realização da mesma deveria ser um município de grande porte. Isso porque, em geral, esses municípios dispõem de uma maior quantidade e diversidade de serviços e estabelecimentos de saúde instalados em seu território, o que, em tese, facilitaria a garantia de acesso da população aos distintos níveis de complexidade da atenção à saúde.

Partindo desse pressuposto, decidiu-se enfrentar o desafio de realizar a pesquisa no município de São Paulo, capital de estado e sede da maior região metropolitana. Esse município tem uma população residente estimada em cerca de 11 milhões de habitantes e é responsável pelo quarto maior PIB (produto interno bruto) brasileiro, atrás apenas dos estados de São Paulo, Rio de Janeiro e Minas Gerais (SÃO PAULO, 2008). A cidade é um importante centro comercial e industrial, com grande capacidade de investimento e com relativa autonomia financeira em relação à parcela do financiamento do Ministério da Saúde. Possui a maior rede de serviços de saúde 
pública e privada do país, sendo que alguns desses são referências de caráter nacional para procedimentos de alta complexidade.

A Secretaria Municipal de Saúde (SMS-SP) possui uma complexa estrutura administrativa, tendo experimentado distintos modelos de gestão e de atenção, incluindo o PAS (Plano de Atendimento à Saúde) e Organizações Sociais, entre 1996 e 2008. Após período de seis anos de PAS, em que não foram respeitados princípios constitucionais do SUS, a gestão iniciada em 2001 assumiu o compromisso político de reconstruir o sistema de saúde, no município de São Paulo. No início dessa administração, a SMS-SP viabilizou a habilitação do município na condição de gestão plena da atenção básica e, a partir de junho de 2003, na condição de gestão plena do sistema municipal de saúde (BRASIL.MS, 2003). Nessa gestão, foram organizados 41 Distritos de Saúde que, posteriormente, com a descentralização do governo municipal em 31 Subprefeituras, foram reorganizados em 31 Coordenadorias de Saúde.

Em 2005, a nova gestão municipal implementou uma reforma administrativa organizando cinco novas Coordenadorias Regionais de Saúde (CRSs) a partir das antigas Coordenadorias de Saúde, que foram reagrupadas. Para dar funcionalidade às novas CRSs, foram criadas 24 Supervisões Técnicas de Saúde (STSs).

Nesse contexto, as questões que nortearam o desenvolvimento desta pesquisa foram: a) Como o princípio da integralidade vem sendo incorporado na gestão do sistema municipal de saúde e na organização dos serviços no município de São Paulo? b) Quais são os fatores que têm facilitado e/ou dificultado a operacionalização desse princípio no SUS no município de São Paulo? 


\section{OBJETIVOS}




\section{OBJETIVOS}

\subsection{GERAL}

- avaliar a incorporação do princípio da integralidade na gestão e organização dos serviços de saúde em um território selecionado do município de São Paulo, SP.

\subsection{ESPECÍFICOS}

Os objetivos específicos da pesquisa são avaliar:

- estruturas existentes e mecanismos utilizados na gestão locorregional que possibilitam a implementação da integralidade da assistência, no âmbito do território selecionado;

- fatores que facilitam e que dificultam a implementação da integralidade da assistência na realidade locorregional. 
MÉTODOS 


\section{MÉTODOS}

A escolha de um método que oriente o caminho para uma aproximação a realidades complexas, como aquelas relacionadas ao campo da saúde coletiva, em geral, e da política e gestão em saúde, em particular, representa um dos principais desafios para o pesquisador. Contudo, é indispensável fazer uma escolha, dentre as inúmeras possibilidades, tendo claro que o produto de uma pesquisa será sempre "provisório". O conhecimento produzido sempre será aproximado, parcial e implicado. Na medida em que não é possível dissociar sujeito e objeto da pesquisa, a visão de mundo de ambos está implicada em todo o processo de conhecimento (MINAYO, 1994).

Nessa mesma direção, SANTOS (2003) considera que os pressupostos metafísicos, os sistemas de crenças e os juízos de valor são parte integrante da explicação científica da sociedade. Para esse autor, o conhecimento pós-moderno se constitui a partir de uma pluralidade metodológica, sendo que "cada método é uma linguagem e a realidade responde na língua em que é perguntada” (p. 77).

É importante considerar que o pesquisador se encontra inserido em relações sociais com o campo, buscando traduzir o sentido das narrativas que se apresentam nessa relação. Nesse sentido, a pesquisa social não teria a pretensão de explicar uma realidade em si, de produzir “(...) conhecimentos absolutos, mas interpretações plausíveis. (...) A pesquisa produz interpretações que buscam dar sentido aos modos nos quais os atores buscam, por sua vez, dar sentido às suas ações. Trata-se de relatos de sentidos, ou, se queremos, de narrações de narrações” (MELUCCI, 2005, p. 33). 
Para a realização desta pesquisa e em função da complexidade do tema e da realidade social à qual se buscava aproximar, a estratégia metodológica escolhida foi a de um estudo de caso. Este é caracterizado como uma investigação empírica que explora um fenômeno contemporâneo complexo, em seu contexto, especialmente quando os limites entre o fenômeno e o contexto não estão claramente definidos (YIN, 2005; MINAYO, 1994; GODOY, 1995; DENIS e CHAMPAGNE, 1997). O estudo de caso tem como objetivos, de um lado, a tentativa de compreender o fenômeno em estudo e, por outro, a tentativa de desenvolver teorias mais gerais; nesse sentido, articula questões empíricas e teórico-conceituais (DESLANDES e GOMES, 2004). Em função dessas características, essa estratégia tem sido freqüentemente utilizada em pesquisas sobre política e administração públicas, em particular, no campo da saúde (YIN, 2005; DESLANDES e GOMES, 2004).

As fontes de evidência utilizadas para seu desenvolvimento foram: a) documentos da gestão (plano de saúde, portarias, decretos, documentos internos e atas de reunião); b) entrevistas não-estruturadas com informantes-chaves (Anexo 1), selecionados entre gestores do SUS no município de São Paulo; c) grupo focal com usuários; e observação direta.

As entrevistas foram realizadas pelos próprios pesquisadores, gravadas e, posteriormente, transcritas por assistentes de pesquisa. Após a apresentação dos objetivos da pesquisa e do tema central da mesma, o entrevistado transcorria livremente sobre o tema. Com apoio de um roteiro básico, os entrevistadores solicitaram, quando necessário, o aprofundamento de alguns pontos relevantes para a pesquisa. Foram entrevistados sete gestores da SMS-SP, tanto do nível locorregional 
quanto assessores do Gabinete, e um gestor da Secretaria de Estado da Saúde de São Paulo (SES-SP) - assessor técnico do Gabinete.

Alguns documentos da gestão foram disponibilizados pelos gestores nos contatos para apresentação e negociação do projeto de pesquisa e no momento das entrevistas. Outros foram localizados na página institucional da prefeitura do município de São Paulo, na rede virtual web.

O grupo focal (CARLINI-COTRIM, 1996) foi realizado com usuários de uma das Unidades Básicas de Saúde (UBS) da região estudada. O critério utilizado para seleção dos participantes foi serem portadores de Hipertensão Arterial Sistêmica, por se tratar de uma doença crônica, de alta prevalência entre a população adulta e que necessita para seu acompanhamento exames e consultas especializadas, segundo critérios estabelecidos em protocolos clínicos e programas oficiais. Dos 15 usuários selecionados e convidados, sete participaram do grupo. O tema apresentado para a discussão do grupo foi "as facilidades e dificuldades encontradas para acessar os serviços de referência (para realizar exames complementares ou consulta médica especializada)".

A observação direta foi desenvolvida em visitas a serviços de saúde, conversas com gestores e trabalhadores da região estudada e no processo de seleção e organização do grupo focal. Os dados foram registrados em diário de campo.

A aproximação ao campo da pesquisa teve início em agosto de 2005, após a aprovação do projeto pela Fapesp e com o parecer favorável do Comitê de Ética em Pesquisa da Faculdade de Saúde Pública da Universidade de São Paulo. Foram realizadas duas reuniões, no gabinete da SMS-SP, envolvendo a equipe da pesquisa e 
a Coordenação de Práticas Assistenciais, sua assessoria e a Coordenadoria Regional de Saúde Sudeste (CRS-SE). Nessas reuniões, além da apresentação do projeto de pesquisa, buscou-se negociar a inserção dos pesquisadores no campo visando o desenvolvimento das atividades previstas.

É oportuno destacar que, nesse processo, foram identificadas algumas resistências por parte da SMS-SP, materializadas na dificuldade de acesso a alguns documentos; restrições quanto à realização da observação de alguns espaços da gestão, e, ainda, demora para agendar as entrevistas. Em decorrência desse fato, o trabalho de campo se estendeu além do tempo previsto e, também, houve a necessidade de readequação do projeto.

\subsection{O TERRITÓRIO SELECIONADO}

Considerando a dimensão do município de São Paulo, a complexidade de sua rede de serviços de saúde e os objetivos deste estudo, optamos por localizá-lo em uma região específica do município: o território da Subprefeitura do Ipiranga. Na atual organização política administrativa da Secretaria Municipal de Saúde de São Paulo (SMS-SP), o território dessa Subprefeitura foi assumido como a base territorial de uma Supervisão Técnica de Saúde, que está subordinada à Coordenadoria Regional de Saúde Sudeste (mapa). A Subprefeitura do Ipiranga localiza-se na região sudeste do município de São Paulo e é composto por três Distritos Administrativos: Ipiranga, 
Cursino e Sacomã, que em conjunto ocupam uma área de $37,5 \mathrm{~km}^{2}$ e tem uma população estimada em cerca de 430 mil habitantes.

Nesse território estão localizados, além de diversos serviços privados, alguns contratados pelo SUS, os seguintes serviços públicos de saúde, sob a administração municipal:

- 19 Unidades Básicas de Saúde

- 1 Ambulatório de Especialidades

- $\quad 4$ AMAs (Assistência Médica Ambulatorial)

- 1 CAPS (Centro de Atenção Psicossocial) para criança e adolescente

- 1 SAE DST/AIDS (Serviço de Atendimento Especializado em DST/AIDS)

- 2 Centros de Especialidades Odontológicas

- 1 Laboratório Clínico

- 1 Pronto Socorro

- $\quad 1$ NISA (Núcleo integrado de saúde auditiva)

- $\quad 1$ NIR (Núcleo integrado de reabilitação)

E, ainda, os seguintes serviços, vinculados e gerenciados pela Secretaria de Estado da Saúde (SES-SP):

- 1 NGA (Núcleo de Gestão Ambulatorial - ambulatório de especialidades)

- 1 Hospital de Especialidades, com 404 leitos

- 1 Hospital de Especialidades, com 241 leitos ( com ambulatório anexo)

- 1 Hospital Psiquiátrico

O critério principal para a escolha desse território foi o fato de o mesmo ter condições potenciais para se constituir em um sistema local de saúde. Contempla serviços de saúde de distintos níveis de complexidade, com uma boa cobertura da atenção básica e um movimento social organizado e atuante na saúde. Destaca-se, 
ainda, que a unidade político-administrativa do território foi mantida durante as duas gestões municipais pós-2001 como: Distritos de Saúde do Ipiranga e do Sacomã (2001-2003); Coordenação de Saúde do Ipiranga (2003-2005); e Supervisão Técnica de Saúde do Ipiranga (2005-atual).

A organização de Sistemas Locais de Saúde (SILOS) foi proposta como uma estratégia de transformação dos sistemas nacionais de saúde, possibilitando ampliar a democratização dos serviços de saúde, a participação social e a capacidade de responder às necessidades em saúde da população, visando a eqüidade, efetividade e eficiência das ações e serviços saúde (OPS, 1990).

No Brasil, essa proposta foi incorporada na pauta do movimento da Reforma Sanitária, com a denominação de Distritos Sanitários (DS), e contemplada no texto da Lei Orgânica da Saúde (Lei $n^{\circ}$ 8.080) enquanto uma das estratégias para organização dos sistemas municipais de saúde, visando à integração e articulação das ações.

No processo de municipalização do SUS, vários municípios brasileiros organizaram seus sistemas municipais de saúde a partir da estruturação de DSs. No entanto, observam-se diferenças entre essas experiências provavelmente relacionadas à concepção de DS que as embasou. Muitos DSs foram implementados apoiados apenas na visão técnico-racionalizadora de um novo arranjo organizacional dos serviços de saúde. Por outro lado, alguns municípios implementaram DSs como uma estratégia para mudança do modelo assistencial, concebendo-o como processo social de transformação das práticas de saúde. 
Nesse sentido, é importante considerar o potencial do DS como um espaço privilegiado para que distintos atores possam se manifestar e negociar a organização dos serviços de saúde em um sistema local de saúde e a efetivação dos princípios do SUS para responder as necessidades de saúde da população. 


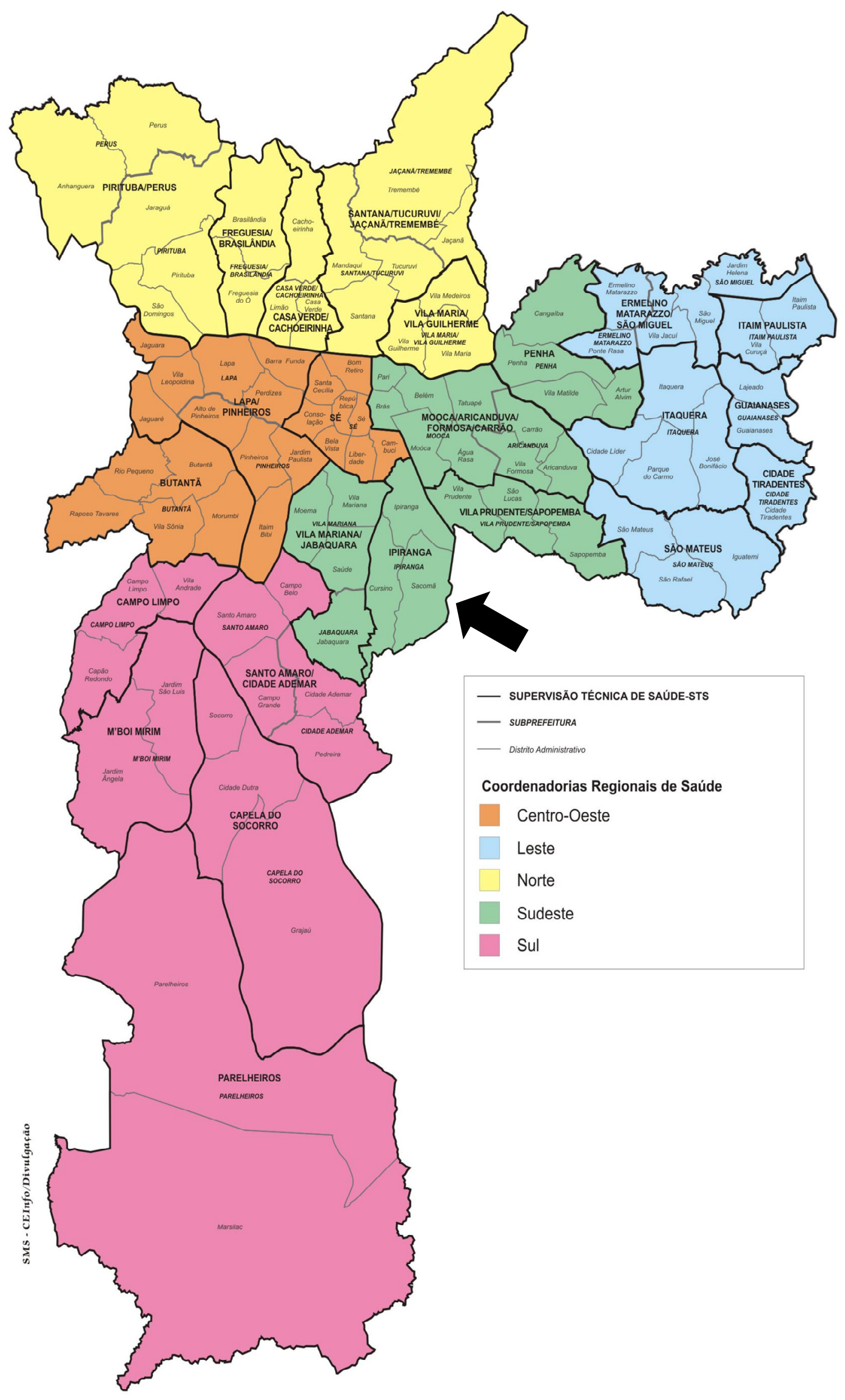




\subsection{VARIÁVEIS PARA AVALIAR A INTEGRALIDADE}

Dadas a diversidade de significados de integralidade e a interdependência entre suas distintas dimensões, as propostas de avaliação que contemplam essa temática são também bastante distintas (CONILL, 2004). Considerando, ainda, a concepção de integralidade assumida neste estudo e os objetivos desta pesquisa elegemos algumas variáveis para orientar/balizar a coleta e análise de dados. Para tanto, utilizamos como referência a metodologia proposta por GIOVANELLA e col. (2002) para a avaliação da integralidade em sistemas municipais de saúde.

O instrumento elaborado por esses autores contempla atributos, correspondentes à organização e processo de gestão do sistema de saúde, considerados facilitadores para a efetivação da integralidade. O conceito que embasou essa metodologia considerou quatro dimensões de integralidade: a) primazia das ações de promoção e prevenção; b) garantia de atenção nos três níveis de complexidade da assistência médica; c) articulação das ações de promoção, prevenção e recuperação; d) abordagem integral do indivíduo (GIOVANELLA e col., 2002).

Para esta pesquisa, foram definidas as seguintes variáveis relacionadas à dimensão da garantia de atenção nos distintos níveis de assistência médica, identificadas como atributos da estrutura e gestão locorregionais necessários para a integralidade:

- Estrutura organizacional do SUS locorregional

- Existência de projetos político-institucionais visando à integralidade da atenção

- Organização e funcionamento do sistema de referência (fluxo dos pacientes)

- Estrutura e funcionamento da regulação do sistema de saúde 
- Uso de protocolos assistenciais

A estrutura organizacional do SUS locorregional (CRS-SE e STS-Ipiranga) foi avaliada a partir de dados coletados em: documentos oficiais (decretos, portarias) obtidos no Diário Oficial do Município de São Paulo, na página institucional da SMS-SP disponível na web. Dada a existência de um número limitado de documentos, os dados obtidos em entrevistas e na observação foram fundamentais nesse processo.

O plano plurianual do município (PPA 2006-2009) e o plano plurianual regional serviram como parâmetros para a avaliação das ações e projetos efetivamente implementados. Esses documentos foram obtidos na página institucional da SMS-SP na $w e b$ e no contato com gestores regionais.

A organização e o funcionamento do sistema de referência e regulação foram avaliados, centralmente, por meio de entrevistas com gestores e técnicos de serviços de saúde selecionados, dada a inexistência de documentos sobre o tema. Para refinar essa avaliação foi realizado um grupo focal com usuários de uma UBS da STS Ipiranga.

As informações sobre o uso de protocolos foram obtidas durante as entrevistas. Não foi disponibilizado nenhum material impresso e tampouco foi encontrada qualquer informação sobre esse tema na página institucional da SMS-SP. 


\subsection{ANÁLISE DO MATERIAL}

Considerando o referencial metodológico da pesquisa, a análise dos dados foi realizada a partir da análise temática, que se constitui em das técnicas utilizadas na análise de conteúdo. Nessa técnica, o tema é uma "unidade de significação que se liberta naturalmente de um texto analisado segundo certos critérios relativos à teoria que serve de guia à leitura” (BARDIN, 2004, p. 105).

Iniciou-se o processo de análise pela leitura "flutuante", do material coletado entrevistas e documentos. A partir dos discursos dos entrevistados, foram identificados "temas" que possibilitaram sua, posterior, categorização. As principais categorias elaboradas, com base nesse material, foram; capacidade de gestão do nível locorregional do SUS; autonomia e governabilidade do gestor locorregional; acesso aos serviços especializados; regulação do sistema; o hospital no sistema locorregional.

Com base nessas categorias e dialogando com o referencial teórico da pesquisa, bem como considerando a necessidade de adequação do material analisado para elaboração de artigos em periódicos do campo da Saúde Coletiva, foram escolhidos três temas para esse fim. A descentralização da gestão municipal enquanto dimensão político-administrativa com potencial para favorecer a governabilidade do gestor locorregional. A regionalização intramunicipal como estratégia para organizar os serviços em um sistema local de saúde visando facilitar a implementação da integralidade da atenção. O acesso a ações e serviços de média complexidade, cuja garantia é condição para a continuidade do cuidado, visando à integralidade. 


\subsection{ASPECTOS ÉTICOS}

Considerando-se que o objeto da presente pesquisa é a avaliação da gestão e organização do sistema e serviços saúde, avaliou-se que pesquisa proposta não apresenta riscos para seus participantes. Preservou-se o anonimato dos entrevistados, utilizando-se códigos ou a função ocupada como critério para apresentação de seus relatos.

Os informantes-chaves selecionados para entrevistas individuais, bem como os usuários selecionados para participar dos grupos focais, foram devidamente esclarecidos e convidados a participar. Aos que aceitaram, foi solicitado seu consentimento para o uso das informações fornecidas, por intermédio de formulário específico - o Termo de Consentimento Livre e Esclarecido. Foi entregue, ainda, para os gestores entrevistados, um Termo de Responsabilidade, que assegurava seu anonimato e que as informações fornecidas seriam utilizadas exclusivamente em trabalhos de cunho acadêmico vinculados à pesquisa.

$\mathrm{O}$ projeto de pesquisa, ao qual este subprojeto estava vinculado, intitulado “ $O$ processo de (re)construção do Sistema Único de Saúde no município de São Paulo. Uma avaliação sobre a incorporação do princípio da integralidade na política municipal de saúde" foi submetido aos Comitês de Ética em Pesquisa: (a) da Faculdade de Saúde Pública (COEP/FSP-USP - parecer favorável em 10/8/2005); e (b) da Secretaria Municipal de Saúde de São Paulo (CEP/SMS - parecer favorável em 27/9/2005). 


\section{RESULTADOS}




\section{RESULTADOS}

\subsection{O DESAFIO DA DESCENTRALIZAÇÃO DO SISTEMA ÚNICO DE} SAÚDE (SUS) EM MUNICÍPIO DE GRANDE PORTE: O CASO DE SÃO PAULO (SP), BRASIL

O artigo “O desafio da descentralização do Sistema Único de Saúde (SUS) em município de grande porte: o caso de São Paulo (SP), Brasil” foi formatado, seguindo as orientações para publicação e apresentado aos editores do periódico: Cadernos de Saúde Pública, que é uma publicação da Escola Nacional de Saúde Pública ‘Sérgio Arouca’, da Fundação Osvaldo Cruz, Rio de Janeiro (RJ).

Situação: Encaminhado em julho de 2008

Em processo de avaliação. Aguardando parecer 
O desafio da descentralização do Sistema Único de Saúde (SUS) em município de grande porte: o caso de São Paulo (SP), Brasil

The challenge of Brazilian Health System (SUS) decentralization in big cities: the case of São Paulo (SP), Brazil

Sandra Maria Spedo ${ }^{1,2}$

Nicanor Rodrigues da Silva Pinto ${ }^{1,2}$

Oswaldo Yoshimi Tanaka ${ }^{1}$

${ }^{1}$ Faculdade de Saúde Pública, Universidade de São Paulo.

${ }^{2}$ Departamento de Medicina Preventiva, Universidade Federal de São Paulo

Correspondência:

Sandra Maria Spedo

Universidade Federal de São Paulo

Departamento de Medicina Preventiva

Rua Botucatu, 740 - Vila Clementino

04023-900 São Paulo-SP Brasil

smspedo@medprev.epm.br 


\section{RESUMO}

A descentralização do SUS ainda enfrenta importantes desafios, em particular a busca de alternativas para grandes municípios. Por se caracterizar como um processo eminentemente político, variáveis político-institucionais, dentre as quais se destaca a capacidade de gestão do nível local, são determinantes para a conformação da descentralização em cada contexto. Utilizando o referencial do triângulo de governo para avaliar a capacidade de gestão, realizou-se um estudo de caso, com o objetivo de analisar o processo de descentralização do SUS no município de São Paulo, a maior metrópole brasileira. A partir da análise de entrevistas com gestores selecionados e documentos da gestão, identificou-se um movimento de centralização da saúde na gestão municipal 2005-2008, acompanhado da desestruturação das estruturas locorregionais da Secretaria Municipal de Saúde, o que resultou no esvaziamento técnico e político dessas instâncias. Apesar dos limites da descentralização, destaca-se sua potência enquanto estratégia operacional para alcançar os objetivos do SUS. Aponta-se a necessidade de retomar o processo de descentralização da saúde no município de São Paulo que, além de avançar para instâncias locorregionais, esteja articulado à descentralização da gestão pública municipal.

Palavras-chave: Gestão em saúde; Descentralização; Política de Saúde; Sistemas de Saúde; SUS (BR). 


\section{ABSTRACT}

The decentralization of the Brazilian National Health System (SUS) still faces challenges to be implemented in the big cities. As a public policy, the institutional variables found in different social and political contexts influence the local government capability to manage the health system. This is a case study developed in São Paulo city and the data analysis was focused on the decentralization process using a theoretical reference of the strategic planning. Documents from health administration and managers interviews were the main sources of data. In the period of 2005-08, it was identified an administrative centralization process that resulted in a weakness of the governance at local and regional levels of the City Health Secretariat. The decentralization operational strategy has the potential to strengthen the SUS objectives although the context limits in its implementation. This study identified the need to recover the decentralization process in São Paulo city to aim the local and regional health levels to implement the SUS principles.

Keywords: Health Management; Decentralization; Health Policy; Health Systems; SUS (BR). 


\section{INTRODUÇÃO}

A descentralização do sistema e serviços de saúde implementada, no Brasil a partir da década de 1990, representou importante avanço no sentido da construção do Sistema Único de Saúde (SUS) ${ }^{1,2,3}$. No entanto, deve-se considerar que esse processo foi impulsionado e induzido pelo Ministério da Saúde a partir da edição de sucessivos instrumentos normativos, as Normas Operacionais Básicas do SUS (NOBs), editados a partir de 1991, o que foi caracterizado como um "certo jeito $N O B$ de fazer o SUS, esculpindo-o a golpes de portaria" ${ }^{\text {. A }}$ A rigidez normativa e o detalhamento excessivo desses instrumentos representam limitações à operacionalização da descentralização a partir de uma pactuação que considere a realidade loco-regional e a assimetria dos municípios brasileiros. Com isso, foram constituídos sistemas municipais de saúde, independentemente da capacidade de governo dos municípios para assumir esse papel e, ainda, sem uma participação efetiva dos níveis estadual e federal.

Assim, coexistem subsistemas de saúde descentralizados bastante heterogêneos, com distintos potenciais resolutivos, atomizados e desarticulados. Esse fato representa um constrangimento para a efetivação da integralidade da atenção à saúde e, além disso, um risco no sentido de aprofundar ainda mais as desigualdades na oferta e acesso aos serviços de saúde.

Saliente-se que esse processo de descentralização, ainda em curso no país, enfrenta, também, contradições político-ideológicas de distintos projetos de sociedade e, conseqüentemente do papel do Estado. Por um lado, o projeto da Reforma Sanitária 
defende a descentralização, num contexto de redemocratização da sociedade, enquanto uma estratégia para aproximar os serviços às necessidades dos cidadãos, ampliando os espaços democráticos, a participação e o poder local ${ }^{5}$. Por outro, o projeto de Reforma do Estado, que defende a descentralização como estratégia de modernização da administração pública, reduzindo o papel do Estado e compartilhando a responsabilidade com a sociedade e o mercado ${ }^{6,7}$.

É importante considerar, também, que a descentralização pode se identificar com várias ideologias, pois “cada um encontra na Descentralização aquilo que considera mais oportuno e conveniente encontrar" ${ }^{\text {}}$. Dessa forma, é fundamental reconhecer os atores sociais, suas ideologias, presentes em uma determinada conjuntura política para que se possam identificar potências e limites da descentralização.

No que concerne às questões de Estado, a descentralização pode ser caracterizada, ainda, como um "modo de ser do aparelho político ou administrativo", apresentando-se sempre associada à centralização, como ordenamentos jurídicos na organização do Estado ${ }^{8}$. Nesse sentido, dificilmente a descentralização é encontrada em seu estado puro.

A partir dessas considerações, é possível compreender que a descentralização da política de saúde dificilmente será efetivada em sua radicalidade. Haverá sempre a coexistência com um grau variável de centralização, na dependência das forças políticas atuantes em cada momento histórico.

Considerando o desafio do SUS, a proposta de descentralização, que implica na transferência de poder e competências do nível central para os níveis locais, 
pressupõe a definição de novas competências para os entes federados envolvidos, bem como a organização de novas estruturas administrativas 9 . Para que esse novo arranjo seja efetivo, deve-se consolidar a capacidade de cada ente para executar novas funções e interagir com funções executadas pelas demais esferas de governo, mantendo um equilíbrio entre autonomia e interdependência ${ }^{10}$.

Por se tratar de um processo político, além das políticas de indução emanadas pelo Ministério da Saúde, as variáveis político-institucionais locais são determinantes para a conformação que a descentralização assume em cada região. Dentre essas variáveis, destaca-se a capacidade de gestão do nível local para assumir e conduzir com responsabilidade as políticas sociais ${ }^{1,11}$.

Em estudo realizado com o objetivo de analisar a gestão descentralizada do SUS os autores concluíram que "as melhores condições de oferta estão associadas ao alto aprendizado institucional, maior capacidade de gasto e maior gasto com pessoal, isto é, máquinas administrativas mais robustas"2. Entretanto, outra pesquisa, realizada no mesmo período, problematiza essa questão ao discutir que os municípios de maior porte, em geral, enfrentaram mais dificuldades para assumirem a totalidade dos serviços quando foram habilitados na condição de Gestão Plena do Sistema Municipal de Saúde. Segundo esse autor, "a descentralização dos serviços e funções do estado para capitais é, quase sempre mais conflituosa do que para os demais municípios" ${ }^{\prime 12}$.

Nesse sentido, este artigo tem como objetivo analisar o processo de descentralização do SUS no município de São Paulo (SP). 


\section{MÉTODOS}

No Brasil, o município é identificado como o espaço onde se "materializa o resultado da descentralização". Contudo, na medida em que esse processo envolve relações entre as três esferas de governo (município, estado e união), propõe-se que avaliações sobre a descentralização contemplem essa temática ${ }^{13,14}$.

O presente estudo, apesar de ter o campo circunscrito ao espaço singular de um município, incorpora na análise e discussão elementos do espaço geral, relacionado ao contexto nacional e do espaço particular, referente ao contexto estadual.

A estratégia utilizada para o desenvolvimento da pesquisa foi o estudo de caso que é caracterizado como uma investigação empírica de um fenômeno contemporâneo complexo, em seu contexto, especialmente quando os limites entre o fenômeno e o contexto não estão claramente definidos ${ }^{15}$. O estudo de caso tem como objetivos, de um lado, tentar compreender o fenômeno em estudo e, por outro, tentar desenvolver teorias mais gerais. Em função dessas características, essa estratégia tem sido freqüentemente utilizada em pesquisas sobre política e administração públicas, em particular, no campo da saúde ${ }^{16}$.

Em função da extensa dimensão territorial e da complexidade do município de São Paulo, optou-se por delimitar o campo deste estudo a uma região desse município, que reunisse características compatíveis com um sistema local de saúde. Os principais critérios utilizados para essa seleção foram: existência de serviços públicos de saúde, em quantidade e de distintos níveis de complexidade, e existência de estrutura político-administrativa da saúde, no território. A partir de um processo de 
negociação junto a Secretaria Municipal de Saúde (SMS-SP), foi selecionada uma Supervisão Técnica de Saúde (STS). A pesquisa abarcou o período da gestão municipal de 2005-2008.

O território, sob a responsabilidade da STS selecionada, coincide com o de uma Subprefeitura, que compreende três Distritos Administrativos e tem uma população residente estimada em pouco mais de 430 mil habitantes. É importante considerar que, em termos populacionais, essa Subprefeitura é maior do que 96\% dos municípios brasileiros, sendo que apenas 32 deles têm população maior que 500 mil habitantes ${ }^{17}$.

Nessa região, está situado um número significativo de serviços públicos de saúde, sob gestão municipal: 18 Unidades Básicas de Saúde (UBSs); um Ambulatório de Especialidades; um Centro de Atenção Psicossocial para criança e adolescente; um Serviço de Atendimento Especializado em DST/AIDS; dois Centros de Especialidades Odontológicas; três unidades de Assistência Médica Ambulatorial (AMA); um Pronto Socorro; um Laboratório Clínico. Além desses, existem outros serviços públicos que se encontram sob dupla gestão, da Secretaria de Estado da Saúde (SES-SP) e da SMS-SP: um Núcleo de Gestão Ambulatorial (ambulatório de especialidades); um Hospital de Especialidades Estadual com 359 leitos; um Hospital de Especialidades, com 525 leitos e Ambulatório de Especialidades anexo; e um Hospital Psiquiátrico.

As principais fontes de dados utilizadas foram: entrevistas semi-estruturadas com informantes-chaves, selecionados entre os gestores da SMS e documentos da gestão 
(decretos, resoluções, documentos elaborados pelas equipes regionais). Os entrevistados eram esclarecidos sobre o tema central e, após uma livre explanação, respondiam a perguntas específicas sobre temas não abordados na fala inicial, e de interesse para a pesquisa. Foram entrevistados o supervisor da STS selecionada e dois coordenadores de Coordenadorias Regionais de Saúde (CRS), sendo um deles da CRS correspondente à STS selecionada. As entrevistas foram gravadas e, posteriormente, transcritas por assistentes de pesquisa.

A partir do trabalho de campo foram identificadas e construídas categorias empíricas que possibilitassem uma melhor apreensão da realidade em estudo: capacidade de gestão locorregional e poder de decisão/negociação do gestor locorregional. Para a análise, utilizou-se o referencial teórico do triângulo de governo ${ }^{18}$ enquanto categoria analítica. É importante registrar que o conceito de triângulo de governo está relacionado com o ato de governar e exige a articulação de três variáveis: projeto de governo, capacidade de governo e governabilidade do sistema ${ }^{18}$.

Com base no conceito do triângulo de governo, foi elaborado um modelo teóricológico, que corresponde à imagem-objetivo da organização do SUS e que foi utilizado como parâmetro para análise da implantação da gestão descentralizada da saúde $^{14}$. Para os autores desse modelo, a articulação efetiva entre os componentes do triângulo de governo no processo de descentralização levaria ao fortalecimento do poder local, das instituições públicas e da capacidade de gestão dos sistemas de saúde. 
O projeto de pesquisa foi aprovado pelos Comitês de Ética em Pesquisa da Faculdade de Saúde Pública da USP e da Secretaria Municipal de Saúde de São Paulo, com base na Resolução n 196/96 do Conselho Nacional de Saúde.

\section{RESULTADOS}

Apresenta-se inicialmente uma breve análise do contexto do SUS no município de São Paulo, realizada a partir de documentos, focalizando a dimensão de sua organização político-administrativa; e a seguir, a análise, centrada nas entrevistas, da gestão do SUS no nível locorregional.

\section{O contexto da descentralização do SUS no município de São Paulo}

No processo de (re)construção do SUS, no município de São Paulo, iniciado em 2001, a organização de Distritos de Saúde foi a estratégia assumida para operacionalizar a descentralização no âmbito municipal. Essa ação setorial estava em consonância com o projeto de descentralização política e administrativa do governo municipal que foi concretizado em 2002 com a criação de 31 Subprefeituras.

A Subprefeitura se constituiu como instância regional da administração direta, destacando-se dentre suas atribuições: "planejar, controlar e executar os sistemas locais, obedecidas as políticas, diretrizes e programas fixados pela instância central da administração; (...) ampliar a oferta, agilizar e melhorar a qualidade dos serviços locais, a partir das diretrizes centrais; (...) facilitar o acesso e imprimir transparência aos serviços públicos, tornando-os mais próximos dos cidadãos” 19. 
Esse projeto representava um avanço importante no sentido da descentralização da administração municipal, por aproximar a gestão aos espaços sub-regionais, possibilitando o planejamento e a administração regionalizada. Essa aproximação do poder público ao cidadão, estimulando a participação da população, contribuiria para o incremento da eficiência e eficácia das políticas públicas. As secretarias municipais seriam organismos de planejamento e coordenação das políticas gerais, o que garantiria a unidade municipal das ações governamentais. A execução e o gerenciamento das ações seriam realizados pelas subprefeituras, por meio de Coordenadorias que funcionariam como o poder público no território ${ }^{20}$. Contudo, esse projeto ousado de descentralização do governo municipal foi ‘arquivado' pela gestão municipal que iniciou em 2005.

A partir da implantação das Subprefeituras, os Distritos de Saúde foram reestruturados e transformados em Coordenadorias de Saúde. Essas ficaram subordinadas administrativamente ao Gabinete do Subprefeito e tecnicamente a Secretaria Municipal de Saúde (SMS-SP), sendo responsáveis "pelas ações de assistência à saúde, vigilância sanitária e epidemiológica, recursos humanos e financeiros da Saúde e atividades afins" ${ }^{19}$.

Paralelamente à organização das Coordenadorias de Saúde, a SMS-SP criou, em 2002, as Autarquias Hospitalares visando à modernização da gestão dos serviços hospitalares. Essas tinham como atribuição "a promoção e execução das ações $e$ serviços de saúde de atenção médico hospitalar"21. As cinco Autarquias criadas assumiram a gestão de todas as unidades hospitalares e de urgência e emergência, próprias do município. Naquele momento os hospitais públicos estaduais não foram 
incorporados a SMS-SP e, conseqüentemente às Autarquias, pois o município estava habilitado apenas na Gestão Plena da Atenção Básica. No entanto, essa situação se manteve mesmo após o município assumir a Gestão Plena do Sistema de Saúde em 2003.

Deve-se registrar, ainda, que as Autarquias se constituíram enquanto instâncias autônomas, vinculadas diretamente ao Gabinete do Secretário, dissociadas política e administrativamente das Coordenadorias de Saúde, que seriam responsáveis pela implantação da política municipal de saúde no âmbito regional.

No início de uma nova gestão municipal, em 2005, a SMS-SP implementou uma reforma administrativa, por considerar que a estrutura vigente estava superdimensionada e, ainda, que a descentralização implementada no período anterior teria conduzido as Coordenadorias a uma situação de excessiva autonomia em relação à SMS-SP, dificultando o comando único do SUS no município. Foram organizadas cinco novas Coordenadorias Regionais de Saúde (CRSs) a partir das antigas Coordenadorias de Saúde, que foram reagrupadas e transferidas das Subprefeituras para a SMS-SP. Para dar funcionalidade às novas CRSs, foram criadas 24 Supervisões Técnicas de Saúde (STSs). Esse processo indica um movimento de re-centralização da gestão da saúde no município.

Destaca-se que as tanto as novas CRSs, quanto as STSs, foram criadas com estrutura mínima de cargos e pessoal e atribuições limitadas. As STSs que são responsáveis por territórios populosos, de cerca de 500.000 habitantes, não apresentam sequer estrutura organizacional definida. 
Essa reforma não contemplou mudanças nas Autarquias Hospitalares, mantendo-as com lógica e organização distintas e maior autonomia administrativa do que o restante da rede de serviços de saúde municipal. Embora os limites territoriais das novas Coordenadorias sejam coincidentes com o das Autarquias, observa-se a persistência da dificuldade de articulação entre as mesmas.

Outra questão importante do contexto político-institucional da SMS-SP, observada durante o período da pesquisa, foi uma significativa movimentação em seu quadro de direção. Na gestão 2005-2008, foram registradas três mudanças de secretários de saúde (quatro titulares) e, na região estudada, duas mudanças de coordenadores (três titulares) e quatro de supervisores (cinco titulares).

\section{A gestão do SUS locorregional}

Segundo documento, elaborado pela equipe técnica da CRS estudada, a estruturação das Coordenadorias foi “orientada pela premissa da Secretaria Municipal de Saúde de restabelecer o comando técnico e operacional da Rede Ambulatorial da Saúde Municipal, visando maior eficiência da prestação de serviços de saúde à população". Essa nova organização político-administrativa "visa à integração $e$ organização do sistema de saúde em nível regional, mantendo uma base territorial correspondente à Subprefeitura através das cinco supervisões de saúde que compõem a Coordenação Regional de Saúde” (SMS/CRS-XX). É importante destacar que não foram localizadas em qualquer outro texto oficial, incluso o decreto municipal $^{22}$ que dispõe sobre a reestruturação das Coordenadorias, indicações 
relativas à atribuição e estrutura organizacional dessa estrutura administrativa de SMS-SP.

As STSs, por sua vez, segundo informações contidas no documento supracitado, foram estruturadas segundo critérios populacionais, isto é, cada supervisão abarcaria um território com cerca de 500 mil habitantes. O papel a ser desempenhado pelas mesmas seria: "prioritariamente acompanhar diretamente o trabalho das Unidades de Saúde no território e promover a integração destas com outros recursos desse território, através da atuação conjunta com as Subprefeituras” (SMS/CRS-XX 2005).

Contudo, a estrutura organizacional dessas Supervisões não foi definida, nem tampouco foram criados cargos para as "novas" funções propostas. Apesar da proposta de realocação e contratação de profissionais, visando a "melhoria da gestão”, contida no Planejamento Plurianual (PPA) da CRS, a Tabela de Lotação de Pessoal apresentada não contempla as novas estruturas administrativas: Coordenadoria e Supervisões (SMS/CRS-XX 2005).

O supervisor de saúde entrevistado identifica a falta de estrutura como um limite importante para a gestão locorregional: “(A STS) é uma estrutura muito enxuta e muito centralizada. (...) Eu tenho uma equipe muito reduzida. Na regulação, em particular, eu não tenho nenhum cargo. O meu organograma, eu tava desenhando ele outro dia, eu tenho o supervisor e o corpo de bombeiros embaixo. Eu não tenho uma estrutura administrativa, técnica, (...) são pessoas” 
Nota-se uma contradição entre a precária estrutura existente, reconhecida pelo próprio supervisor, e o discurso manifesto do coordenador, enfatizando a importância da STS para a gestão municipal: “a capilaridade da informação também não chega na porta, por isso que a supervisão pra nós é o maior instrumento dessa gestão. (...) Teve uma série de situações que a gente teve que ir corpo a corpo nas unidades de saúde; então a supervisão foi o carro chefe dessa gestão". (coordenador 1).

Essas falas traduzem perspectivas distintas desses atores quanto às atribuições da Supervisão. Se por um lado, o coordenador tenta destacar a importância dessa estrutura para a gestão, por outro, a narrativa do supervisor aponta que, em decorrência dos limites impostos, o papel possível de se exercer na prática, é ainda mais restrito do que o acompanhamento do trabalho das unidades, proposto no documento.

O supervisor reconhece a necessidade de modificar essa realidade para avançar na organização do SUS regional considerando, inclusive, o potencial dos serviços de saúde existentes no território de abrangência de sua Supervisão.

“Hoje a estrutura definida nessa administração, que eu não concordo muito, eu sou um fiscal, né? Eu tenho um gargalo também. Quer dizer, a coisa é unilateral, quer dizer, eu simplesmente recebo instruções e fiscalizo minhas unidades. (...) Me tiraram o direito de levar propostas".

E, ainda, reforçando esse sentimento de impotência, esse mesmo entrevistado faz um desabafo: "Eu estou murado, a palavra é, eu sinto, a minha sensação hoje como 
supervisor é essa, é murado. Quer dizer, eu me viro com aquilo que eu tenho aqui e com as iniciativas de amigos”.

Pode-se constatar, a partir das entrevistas, que a Supervisão, também, não se constitui em espaço para o planejamento regional. Um dos relatos, concernente à organização regional do programa de DST/AIDS, ilustra bem essa situação:

"São ambulatórios totalmente independentes, a conversação é rara. (...) Pela estrutura dos serviços a gente tem alguma definição. (...) Isso tudo, uma coisa que o vento molda. (...) Em momento nenhum, nós sentamos pra discutir isso. (...) E eu tenho certeza que o programa de AIDS avançaria muito se nós dividíssemos o bolo. (...) O programa municipal, estadual, nacional, ele é muito avançado, ele estimula isso. Mas, a organização do sistema eu acho que deveria partir da Supervisão”. (supervisor)

A baixa governabilidade da STS, aliada à inexistência de planejamento nesse nível, é identificada pelo supervisor, inclusive, no contexto dos projetos prioritários implementados pela própria SMS-SP, envolvendo serviços próprios. De acordo com seu relato, esse gestor não teve qualquer participação no processo de planejamento/decisão da implantação de novos serviços em sua região, como a AMA.

“Fui informado: 'olha, então, o AMA X não sai mais'. (...) O AMA seria instalado em outro local. (...) Aí conversei com meu coordenador e ele falou: 'não sei, não tenho resposta para isso, é uma decisão. Esqueça o X, seu segundo AMA vai ser no Y’. E, eu cumpri ordens, esqueci o X e estamos esperando o Y como AMA, né?”. 
Observa-se muita semelhança entre os relatos de todos os entrevistados sobre os obstáculos enfrentados, no cotidiano da gestão, na tentativa de articulação dos serviços ambulatoriais com os hospitais. Mais precisamente, foi ressaltada a dificuldade em garantir/construir a referência hospitalar.

Deve-se ressaltar que, nesta pesquisa discute-se apenas a relação com hospitais públicos. Isto se deve ao fato de que os entrevistados se referiram exclusivamente a esses serviços, talvez, porque na região estudada os hospitais públicos se constituem de fato na principal referência ou teriam um potencial para tanto.

Alguns gestores relacionaram a dificuldade de articulação à lógica de funcionamento do hospital, enquanto instituição, que muitas vezes não coincide com a necessidade ou demanda dos serviços e usuários que a ele recorrem.

“O hospital gira em torno das suas próprias necessidades. Ele não está preocupado com a necessidade da população como um coletivo, ele tá preocupado com quem chega nele. (...) A gente sabe que, muitas vezes, quem chega na porta nem sempre é quem precisa mais. (...) Os hospitais precisam ter essa consciência de que eles estão trabalhando para a rede básica, que, por sua vez, trabalha para a população. E não o inverso". (coordenador 2)

Considerando que qualquer tentativa de articulação com hospital envolve necessariamente o enfrentamento de questões inerentes à organização dessa instituição, observou-se que foram identificados, ainda, vários obstáculos de outra ordem, mais relacionados à organização dos serviços e sistema de saúde. Nessa direção, foram apontadas distintas situações que caracterizam as dificuldades 
vivenciadas pelos gestores locorregionais na relação com os hospitais próprios do município.

A manutenção do arranjo organizacional da assistência hospitalar municipal por meio de Autarquias é identificada, por um dos coordenadores de saúde entrevistado, como um obstáculo para a integração dos hospitais com os demais serviços de saúde vinculados à própria SMS.

"Tem cinco Autarquias e cinco Coordenadorias. Mas, não correspondemos, porque as Autarquias não foram construídas na lógica do território. Hospital não trabalha na lógica do território. E, (a Autarquia) foi construída juntando hospitais. (...) A Autarquia continua como uma cisão. (...) A divisão da Coordenadoria e da Autarquia não é nem por níveis de atenção, nem por tipos de atenção; é por quem funciona 12 horas e quem funciona 24 horas". (coordenador 2)

É oportuno lembrar que os limites territoriais das novas Coordenadorias, criadas nessa gestão, são coincidentes com o das Autarquias. No entanto, esse fato por si só não foi suficiente, conforme mostrado acima, para atenuar a dificuldade de articulação entre os serviços de saúde vinculados a essas estruturas.

Por outro lado, as informações obtidas nas entrevistas indicam que a SMS-SP fez uma opção política de estabelecer relação preferencial com os hospitais próprios, apesar da existência de hospitais estaduais de grande porte na região.

“Essa regulação se volta pra dentro da prefeitura, (...) eu já encontro uma coordenação que quase (...) ignora os hospitais estaduais. O que me deixa numa 
situação muito difícil, porque eu só tenho os hospitais estaduais na região. Não tenho hospital municipal. (...) E a coordenação ela simplesmente tende a querer resolver os meus problemas com a rede municipal”. (supervisor)

O coordenador de saúde explicita claramente essa política: “ $O$ (hospital) $X$ não é nossa referência (para as AMAs). (...) (A referência) é o (hospital) Z, porque, assim, nós optamos inicialmente vaga com os da casa. Quem são os da casa? Os municipais. Não vaga com os do território”. (coordenador 1)

É interessante ressaltar que outro gestor entrevistado, fez referência a esse tema assumindo uma postura crítica em relação a essa opção, a qual representa, na prática, um entrave para a integração entre os serviços:

"O próprio gestor municipal, ainda, às vezes, não tá com essa visão de que é o gestor do sistema. Então, (...) ele tem que olhar o sistema como um todo. Não adianta só ver o serviço municipal, entendeu? Tem que ver como um todo”. (coordenador 2)

Assim, fica evidente que a organização do sistema de referência e contra-referência é definida centralmente, desconsiderando, inclusive, os recursos disponíveis em cada região. O supervisor não tem poder de decisão e, sequer, espaço para discutir essa questão.

“Eu não tenho autonomia de ir à Secretaria 'Qual é o quadro de referência, como funciona isso? Prefiro o (hospital) W, que é mais perto'. Não é assim. Isso vem num e-mail: 'Sua referência é o (hospital) Z'. (...) Ele tá numa outra região”. (supervisor) 
Como conseqüência dessa política, a STS estudada é compelida a encaminhar pacientes a um hospital municipal, localizado em outra STS, com acesso mais difícil para o usuário, apesar da existência de hospitais estaduais localizados em seu território. Tanto o gestor quanto o usuário do sistema sofrem, na prática, o impacto dessa centralização administrativa.

Nesse contexto, destacam-se mecanismos informais na negociação entre gestores e gerentes de serviços. Independentemente da natureza administrativa do hospital, o contato pessoal foi destacado, em todas as entrevistas, como uma das ferramentas freqüentemente utilizadas. Dessa forma, são firmados acordos entre colegas e não entre as instituições.

“A relação com o (hospital) $Y$ é muito no doméstico, nas relações individuais: quem conhece quem, amigo de quem, do plantão tal. (...) A relação com o (hospital) X é uma relação boa, (...) muito fácil. Então, passa pelas pessoas. A relação não é (pelo fato do) equipamento ser municipal, ser estadual. Tem passado um pouco pelas pessoas". (coordenador 1$)$

Entretanto, apesar das aparentes facilidades advindas da negociação direta com colegas, foram relatados alguns aspectos negativos decorrentes dessa prática. Esse tipo de articulação resulta em acordos informais, não institucionalizados que, portanto, tem maior probabilidade de serem rompidos, com repercussões importantes na organização dos serviços e na continuidade do cuidado.

"A gente vai trabalhando, comendo mingau pelas bordas, vai tentando. Ou então, você entra num hospital, onde você conhece um gerente. Mas, isso é muito 
complicado. (...) Mas, ainda é um trabalho muito difícil. Ele não é sistêmico. (...) Você consegue um trabalho hoje e, amanhã, muda não sei quem lá e você tem que começar tudo de novo”. (coordenador 2)

Um exemplo da fragilidade desses acordos foi citado pelo supervisor entrevistado. Em decorrência do conhecimento pessoal prévio, esse gestor e o gerente do ambulatório de especialidades, vinculado a um dos hospitais estaduais localizados no território da STS, pactuaram um acordo regional com objetivo de organizar o fluxo de pacientes entre os ambulatórios de especialidade da região. Por decisão do nível central da SES-SP, esse acordo foi rompido, representando um retrocesso para a organização do sistema de saúde regional.

"Uma enfermeira, que é uma das responsáveis pelo ambulatório do hospital, e um colega médico clínico que trabalha lá são grandes amigos de outras administrações, (...) eles vieram me procurar oferecendo um apoio (...), abrindo portas. (...) E, nós equacionamos uma pactuação local. (...) E isso funcionou durante mais ou menos um mês e meio. (...) Isso foi muito positivo, acredito, para os pacientes. (...) Só que, infelizmente, esse acordo acabou se rompendo no momento em que essa enfermeira, ela não tem autonomia pra decidir essas coisas. (...) Nós avançamos muito, foi muito interessante para a região. E, depois, nós retrocedemos à estaca inicial”. (supervisor) 


\section{DISCUSSÃO}

A partir de elementos destacados do cotidiano da gestão locorregional da saúde em um grande município, apresentam-se algumas reflexões sobre a potência e os limites da descentralização, apreendida enquanto uma estratégia operacional utilizada para facilitar a implementação dos princípios finalísticos do SUS.

Os achados da pesquisa evidenciaram a fragilidade da organização políticoadministrativa locorregional da SMS-SP, o que se constitui fator limitante para operacionalização de diretrizes do SUS no município de São Paulo. É importante lembrar que o território sob a responsabilidade de cada STS tem uma dimensão populacional e de serviços de saúde instalados maior do que a maioria dos municípios brasileiros.

O primeiro aspecto a ser destacado é que a política de saúde, da gestão municipal do período estudado, limita o papel e as responsabilidades das novas estruturas políticoadministrativas da SMS-SP. Foi atribuído às STSs o “acompanhamento" das unidades de saúde e às Coordenadorias, apenas, o "comando técnico e operacional da rede ambulatorial de saúde municipal”. Dessa forma, independentemente de outros fatores, a governabilidade, tanto do coordenador regional, quanto do supervisor, foi constrangida a uma parcela dos serviços de saúde e não ao sistema local como um todo.

Identificou-se a mobilização do supervisor no sentido de ampliar sua governabilidade, embora este reconhecesse os limites do seu campo de ação. As iniciativas protagonizadas por esse ator, como por exemplo, o acordo regional com 
um dos hospitais estaduais da região, não foram efetivas para modificar as relações de poder instituídas, nem tampouco tiveram sustentação política. É importante considerar que a manutenção de hospitais na prática sob gestão estadual representa importante fator de limitação da governabilidade, inclusive do gestor municipal do SUS. Apesar de o município de São Paulo ter assumido a gestão plena do sistema de saúde, observou-se que muito pouco se avançou no sentido de integrar efetivamente os hospitais ao sistema de saúde.

A dificuldade enfrentada pela SMS-SP na articulação com hospitais estaduais, cujas direções “eram submetidas a interesses político-partidários” e não aos interesses da política de saúde, já foi discutida anteriormente ${ }^{23}$. Esse estudo caracterizou, ainda, a autonomia dos hospitais em relação ao sistema de saúde, a partir do caso de um dos hospitais da região selecionada para esta pesquisa.

A descentralização do SUS impõe um processo permanente de mediações políticas entre distintos gestores. Na medida em que esses gestores atuam dirigindo, formulando estratégias, produzindo política, eles “conformam e constituem um campo de poder governamental em que ocorrem tensionamentos e mediações políticas contínuas e permanentes. Um campo de gestão permeado pelo poder institucional que opera sob a delegação e a tutela dos detentores de mandato executivo",24.

Nesse sentido, deve-se considerar que algumas iniciativas de gestores e gerentes do SUS no município podem ter resultado em conflitos, internos a SMS e externos, 
envolvendo outros serviços e instituições, o que pode estar relacionado à descontinuidade da gestão.

A estrutura funcional da Supervisão é um dos indicadores de sua capacidade de governo, na medida em que essa capacidade é dependente do capital teórico, instrumental e experiência da equipe ${ }^{18}$. Coerente com a racionalização da administração, uma das diretrizes da gestão municipal, as STSs foram instituídas sem um organograma definido e, ainda sem a criação de novos cargos. Com isso, a STS estudada foi organizada a partir de critérios definidos pelo próprio supervisor, com funcionários de carreira, mas antes de tudo amigos, pessoas com 'boa vontade' ou com interesses particulares para se manterem em cargos administrativos.

Aliada à informalidade da equipe técnica, evidenciou-se inexistência de práticas de planejamento locorregional. Os projetos eram definidos no nível central de SMS-SP e conduzidos pelo supervisor que, por sua vez, apresentava baixíssimo poder de interferência sobre os mesmos. É importante ressaltar que o planejamento é considerado um dos componentes mais importantes para a determinação da capacidade de governo $^{18}$. A ampliação da capacidade de governo, por sua vez, é uma das condições necessárias para que as instâncias locais possam assumir as responsabilidades transferidas no processo de descentralização.

O relato de um coordenador regional corrobora essa análise. Esse assinala que “houve um movimento de centralização extremamente forte” da gestão municipal, na medida em que as decisões e ações propostas não respeitavam o incipiente 
planejamento local. Esse movimento foi acompanhado do esvaziamento técnico e político das estruturas político-administrativas de SMS.

Assim, há indicações de que o papel realizado pelo supervisor é muito mais de um gerente de serviços de saúde do que efetivamente um gestor do SUS em sua região.

\section{CONSIDERAÇÕES FINAIS}

Julgamos importante reafirmar que descentralização não é um fim em si mesmo e, também, não se constitui nem panacéia, nem saída mágica para viabilizar a implantação de políticas públicas ${ }^{7,14,25}$. No entanto, em que pesem os limites da descentralização do SUS, já apontados, entende-se que essa diretriz constitui um meio eficaz e racional para alcançar seus objetivos.

No município de São Paulo, alguns desafios devem ser enfrentados para que se possa avançar no processo de descentralização da saúde. O primeiro grande desafio é assumir de fato a gestão de todo o sistema de saúde do município, o que significa assumir hospitais e ambulatórios que ainda permanecem sob a gestão centralizada da SES-SP.

É necessário avançar na descentralização da própria gestão municipal do SUS para estruturas político-administrativas, como aquelas correspondentes às Supervisões Técnicas de Saúde. Esse processo deve ser implementado de forma a viabilizar a organização de um sistema descentralizado e com autonomia que mantenha o compromisso com a solidariedade e co-responsabilidade. 
Para se enfrentar o desafio da descentralização em municípios de grande porte, é importante considerar experiências internacionais como Buenos Aires, Montevidéu, Berlim, Paris, Barcelona. Nessas metrópoles, foram conduzidos processos de descentralização político-administrativa de seus governos que viabilizaram a criação de estruturas regionais, com distintas configurações, responsáveis pela gestão da política municipal $^{26}$. Tais experiências podem apontar caminhos para que o processo de descentralização do SUS avance para além de uma política setorial isolada.

Nesse sentido, avaliamos que o processo de descentralização no município de São Paulo deve ser implementado de forma a adequar-se ao contexto da maior metrópole brasileira, cujo crescimento desordenado aprofundou as desigualdades regionais. Acreditamos que a descentralização do SUS, nesse município, teria mais potência se estivesse articulada a um processo de descentralização ampliado do governo municipal.

\section{REFERÊNCIAS}

1. Levcovitz E, Lima LD, Machado CV. Política de saúde nos anos 90; relações intergovernamentais e o papel das Normas Operacionais Básicas. Ciênc. Saúde Coletiva 2001; 6(2):269-293.

2. Viana ALA, Heimann LS, Lima LD, Oliveira RG, Rodrigues SH. Mudanças significativas no processo de descentralização do sistema de saúde no Brasil. Cad. Saúde Pública 2002; 18 Supl:139-51.

3. Barata LRB, Tanaka OY, Mendes JDV. 15 anos de SUS: desafios e perspectivas. In: CONASS. Convergências e Divergências sobre Gestão e regionalização do SUS. 2004. p.87-103. www.conass.org.br/admin/arquivos/documenta6.pdf (acessado em 15/Fev/2008). 
4. Goulart FAA. Esculpindo o SUS a golpes de portaria...- considerações sobre o processo de formulação da NOBs. Ciênc. Saúde Coletiva 2001; 6(2):292-300.

5. Campos GW. Efeitos paradoxais da descentralização no Sistema Único de Saúde do Brasil. In: Fleury S, organizador. Democracia, Descentralização e Desenvolvimento: Brasil \& Espanha. Rio de Janeiro: FGV; 2006. p.417-442.

6. Teixeira SMF. Descentralização dos serviços de saúde: dimensões analíticas. Rev. Administração Pública 1990; 24(2):78-99.

7. Ase I. La descentralización de servicios de salud em Córdoba (Argentina): entre La confianza democrática y el desencanto neoliberal. Salud Colectiva, Buenos Aires 2006; 2(2):199-218.

8. Roversi-Monaco F. Descentralização e centralização. In: Bobbio N, Matteuci N, Pasquino G. Dicionário de Política. 7 $\square$ Ed. Brasília-DF: UnB; 1995. p.329-35.

9. Abrucio FL. Para além da descentralização: os desafios da coordenação federativa no Brasil. In: In: Fleury S, organizador. Democracia, Descentralização e Desenvolvimento: Brasil \& Espanha. Rio de Janeiro: FGV; 2006. p.77-125.

10. Luz MT. Duas questões permanentes em um século de políticas de saúde no Brasil republicano. Ciênc. Saúde Coletiva 2000; 5(2):293-312.

11. Guimarães L. Modalidades de descentralización en el sector salud y sus contribuciones a la equidad: elementos fundamentales para la formulación de um marco normativo. Washuington-DC: Organización Panamericana de la Salud (Serie Informes Técnicos $\mathrm{n}^{\circ}$ 76); 2001.

12. Oliveira MHCB. Pactos de gestão: divisão de responsabilidades entre estados e municípios na descentralização. In: Pierantoni CR, Vianna CMM, organizadores. Gestão de Sistemas de Saúde. Rio de Janeiro: UERJ, IMS; 2003. p.59-92.

13. Souza LEPF, Vieira-da-Silva LM, Hartz ZMA. Conferência de consenso sobre a imagem-objetivo da descentralização da atenção à saúde no Brasil. In: Hartz ZMA, Vieira-da-Silva LM, organizadores. Avaliação em saúde: dos modelos teóricos à prática na avaliação de programas e sistemas de saúde. Rio de Janeiro: Fiocruz/Salvador: EDUFBA; 2005. p.65-102.

14. Vieira-da-Silva LM, Hartz ZMA, Chaves SCL, Silva GAP, Paim JS. Análise da implantação da gestão descentralizada em saúde: estudo comparado de cinco casos na Bahia, Brasil. Cad. Saúde Pública 2007; 23(2):355-370. 
15. Yin RK. Estudo de Caso: planejamento e métodos. $3 \square$ ed. Porto Alegre-RS: Bookman; 2005.

16. Deslandes SF, Gomes RA. Pesquisa qualitativa nos serviços de saúde: notas teóricas. In: Bosi MLM, Mercado FJ, organizadores. Pesquisa Qualitativa de Serviços de Saúde. Petrópolis-RJ: Vozes; 2004. p.99-120.

17. Instituto Brasileiro de Geografia e Estatística. Perfil dos Municípios Brasileiros: gestão pública 2001. http://www.ibge.gov.br (acessado em 15/Mai/2008).

18. Matus C. Política, Planejamento \& Governo. Brasília: IPEA; 1993. p.29-62.

19. São Paulo. Lei n. 13.399. Dispõe sobre a criação de Subprefeituras no município de São Paulo, e dá outras providências. Diário Oficial do Município de São Paulo 2002; 2 ago.

20. Secretaria Municipal de Subprefeitura. Descentralização e poder local: a experiência das subprefeituras no município de São Paulo. São Paulo: Hucitec/Finatec; 2004. p.15-33.

21. São Paulo. Lei n. 13.271. Dispõe sobre a descentralização das ações e serviços de saúde no Município de São Paulo, com a criação de entidades autárquicas hospitalares de regime especial. Diário Oficial do Município de São Paulo 2002; 4 jan.

22. São Paulo. Decreto n. 46.209. Dispõe sobre a transferência das Coordenadorias de Saúde das Subprefeituras que especifica para a Secretaria Municipal de Saúde. Diário Oficial do Município de São Paulo 2005; 16 ago.

23. Gerschman S. A Democracia Inconclusa: um estudo da Reforma Sanitária brasileira. $2 \square$ ed. Rio de Janeiro: Fiocruz; 2004. p.199-236.

24. Lotufo M. Sistemas de direção e práticas de gestão governamental em secretarias estaduais de Saúde. Rev. Administração Pública 2007; 41(6):1143-63.

25. Guimarães L, Giovanella L. Entre a cooperação e a competição: percursos da descentralização do setor saúde no Brasil. Rev. Panam. Salud Publica 2004: 16(4):283-88.

26. Santos UP \& Barretta D, organizadores. Subprefeituras: descentralização e participação popular em São Paulo. São Paulo: Hucitec/PMSP; 2004. p.87-114. 
Colaboradores: S.M.Spedo concebeu e planejou o estudo; levantou e analisou os dados e redigiu o artigo. N.R.S.Pinto e O.Y.Tanaka participaram da concepção e planejamento da pesquisa e colaboraram na análise e revisão do texto.

Agradecimentos: A pesquisa que deu origem a este artigo foi financiada (modalidade apoio à pesquisa) pela FAPESP (processo $n^{\circ}$ 05/53846-8) e CNPq (processo $n^{\circ}$ 401903/05-2). 


\subsection{A REGIONALIZAÇÃO INTRAMUNICIPAL DO SISTEMA ÚNICO DE SAÚDE (SUS): UM ESTUDO DE CASO DO MUNICÍPIO DE SÃO PAULO (SP), BRASIL}

O artigo “A regionalização intramunicipal do Sistema Único de Saúde (SUS): um estudo de caso do município de São Paulo (SP), Brasil” foi formatado para ser apresentado aos editores do periódico Saúde e Sociedade, que é uma publicação da Faculdade de Saúde Pública, da Universidade de São Paulo e da Associação Paulista de Saúde Pública, São Paulo (SP). Foram seguidas todas as orientações recomendadas pelo periódico.

Situação atual: Encaminhado em fevereiro de 2009 


\section{A regionalização intramunicipal do Sistema Único de Saúde (SUS): um estudo de caso do município de São Paulo (SP), Brasil ${ }^{2}$}

The intramunicipal regionalization of the Brazilian National Health System (SUS): a case study of São Paulo city (SP), Brazil

\section{Sandra Maria Spedo}

Médica Sanitarista - Depto. Medicina Preventiva, Unifesp. Mestre em Saúde Coletiva (Unicamp). Doutorando em Saúde Pública da Faculdade de Saúde Pública, USP.

Rua Botucatu, 740, CEP: 04123-062, Vila Clementino - São Paulo (SP), Brasil

E-mail: smspedo@medprev.epm.br

\section{Nicanor Rodrigues da Silva Pinto}

Médico Sanitarista - Depto. Medicina Preventiva, Unifesp; Mestre em Ciências da Saúde (Unifesp). Doutorando em Saúde Pública da Faculdade de Saúde Pública, USP.

Rua Botucatu, 740, CEP: 04123-062, Vila Clementino - São Paulo (SP), Brasil

E-mail:nicanor@medprev.epm.br

\section{Oswaldo Yoshimi Tanaka}

Professor Titular - Departamento de Práticas - Faculdade de Saúde Pública, USP. Av. Dr. Arnaldo, 715, CEP: 01246-904, Cerqueira César - São Paulo (SP), Brasil E-mail: oytanaka@usp.br

\footnotetext{
${ }^{2}$ A Pesquisa que originou os dados para realização deste artigo teve apoio financeiro parcial da FAPESP e CNPq.
} 


\section{RESUMO}

A regionalização tem sido apontada como um dos principais desafios para viabilizar a eqüidade e integralidade do SUS. Este artigo teve o objetivo de avaliar o processo de implementação de um projeto de organização de regiões de saúde no município de São Paulo. Para tanto, foi realizado um estudo de caso em uma região selecionada desse município, a partir do referencial da análise de implantação, utilizando-se como fonte de dados documentos da gestão e entrevistas semi-estruturadas com informantes-chaves, da gestão municipal 2005-2008. A análise temática evidenciou que um projeto idealizado no início da gestão não foi efetivamente implementado. Dentre os fatores que interferiram nesse insucesso, destacam-se: a) Secretaria Municipal de Saúde (SMS), além de seu caráter centralizador, manteve estruturas político-administrativas independentes para a gestão da atenção básica e da assistência hospitalar; b) a SMS não assumiu a gerência e gestão de ambulatórios e hospitais estaduais; b) o poder institucional e a resistência dos hospitais em se integrar ao sistema de saúde. Discute-se, ainda, a necessidade de avançar na descentralização intramunicipal do SUS e buscar novas estratégias para a construção de pactos que consigam superar as resistências e articular instituições historicamente consolidadas, visando uma regionalização cooperativa e solidária.

Palavras-chave: regionalização; sistemas locais de saúde; integralidade; gestão em saúde; política de saúde. 


\begin{abstract}
The regionalization has been pointed out as one of most important challenges to push ahead integrality and equity on Brazilian National Health System (SUS). This paper has the objective to evaluate a regional health project implementation process in Sao Paulo city. It is a case study of a selected region in the city based on the theoretical reference of implementation assessment. The data base was management documents and interviews, during the period of 2005-2008. The thematic analysis pointed out that the planned project was not implemented. The main factors involved in it were: a) the Municipal Health Secretariat institutional context was still centralized with a clear break down within the primary health and the hospital care; b) the municipal level had not assumed the management of some ambulatory and hospital premises that was under state management; c) it is still remain hospitals institutional power and resistance to integrate a comprehensive health system. It is important to push ahead the municipal decentralization process in the Brazilian National Health System (SUS) and to find out new strategies to build up political agreements to bypass the institutional resistance and articulation that exists, and then to strengthen the regionalization process more cooperative and effective.
\end{abstract}

Key words: regional health planning; local health systems; integrality; health management; health policy 


\section{INTRODUÇÃO}

As duas primeiras décadas do Sistema Único de Saúde (SUS) foram marcadas por significativos avanços, em que pese a conjuntura política e econômica desfavorável à implementação de uma reforma setorial. No entanto, há que se enfrentarem importantes desafios para caminhar no sentido de alcançar a "imagem objetivo" do SUS, identificado com o projeto da Reforma Sanitária. Dentre esses desafios, destaca-se a regionalização (Campos, 2007).

No plano internacional, relata-se a existência de grande entusiasmo em relação à regionalização das políticas públicas, apesar da ausência de mudanças significativas decorrentes de experiências prévias. Esse movimento é associado, por um lado, às iniciativas de reestruturação das instituições visando sua democratização, maior participação social e aumento da eficiência. Por outro, mais recentemente, emerge também como solução potencial aos desafios da globalização e da necessidade de se reduzir o papel do planejamento central. A diversidade de significados de região em diferentes tempos, lugares, e campos da política é identificada como um problema central para a análise desse processo (Tomblin, 2003).

A proposta de organizar sistemas de saúde regionalizados surgiu inicialmente na União Soviética, pós Revolução Russa, e foi posteriormente adaptada para o ocidente por Dawson em 1920 (Silva e Mendes, 2004). Desde então, essa estratégia vem sendo adotada na estruturação de sistemas nacionais de saúde de diversos países. O paradigma dominante nessas experiências tem sido a regionalização autárquica, na qual existe uma instância mesorregional, com relativa autonomia, responsável pela 
gestão do sistema local de saúde. Nessa condição, o papel dos municípios é secundário, algumas vezes responsável apenas por ações de saúde pública, ou inexistente. Esse é o modelo adotado pelo Reino Unido, Itália, Canadá, países cujos sistemas são referência para o SUS (Mendes, 2001; Mendes, 2004).

No Brasil, em decorrência do padrão singular de descentralização implementado, desenvolveu-se o paradigma da municipalização autárquica, no qual o município é o responsável maior pela gestão do sistema de saúde no âmbito local. Além de nosso país, esse modelo foi adotado apenas pela Finlândia, que já o abandonou. Essa forma de organização do sistema de saúde pode conduzir à fragmentação dos serviços, perda da qualidade e ineficiência na utilização de recursos, na medida em que cada município tende a construir sistemas de saúde fechados (Silva e Mendes, 2004).

As características da municipalização da política de saúde no Brasil estão associadas à história federativa de nosso país. O novo federalismo brasileiro, que nasceu durante o processo de redemocratização do país, tinha como projeto central o fortalecimento dos governos subnacionais e, para parte dos atores envolvidos, a democratização do plano local. Com a promulgação da Constituição Federal de 1988 os municípios obtiveram autonomia inédita, transformando-se em entes federativos, com o mesmo status jurídico que os estados e a União. O discurso do municipalismo autárquico, que acompanhou esse processo, é considerado como um dos obstáculos ao bom desempenho dos municípios. Essa visão incentiva a prefeiturização, a concorrência entre os municípios, reforçando o "modelo predatório e não cooperativo de relações intergovernamentais" (Abrucio, 2005). 
Esse modelo de federalismo está propício a produzir alguns efeitos perversos sobre as políticas públicas, tais como: "superposição de ações; desigualdades territoriais na provisão de serviços; e mínimos denominadores comuns nas políticas nacionais” (Arretche, 2004, p. 22).

Outro aspecto importante nesse padrão de municipalização é associado à indefinição do papel do ente estadual. Essa situação teria propiciado uma "posição de flexibilização" dos governos estaduais que, muitas vezes, se eximiam ou repassavam suas atribuições para os municípios (Abrucio, 2005).

No setor saúde, a municipalização é associada com a constituição de sistemas municipais de saúde bastante heterogêneos e atomizados (Mendes, 2004; Gershman, 2000). Em várias regiões do país, esse processo ocorreu de "forma solitária sem a devida cooperação técnica e financeira dos estados" (Solla, 2006, p. 341). Em estudo realizado no estado de São Paulo, foram identificadas situações em que mesmo municípios pequenos eram forçados a investir recursos próprios para organizar serviços de média e alta complexidade, sem qualquer racionalidade técnica ou econômica (Cecilio e col., 2007).

Nesse contexto, a regionalização dos serviços de saúde se impõe como uma estratégia para superar entraves advindos desse processo de municipalização. A implementação dessa diretriz, referenciada pelo princípio da eqüidade, possibilitaria constituir sistemas regionais com a participação solidária dos três entes federados (municípios, estado e união) visando garantir a integralidade da atenção.

Até o momento, pouco se avançou na implementação da regionalização no SUS. Os primeiros instrumentos normativos editados pelo Ministério da Saúde (MS) não 
priorizaram essa diretriz. Apenas em 2001, a Norma Operacional de Assistência à Saúde (NOAS 01/2001) mudou essa tendência, representando "uma iniciativa concreta e a primeira experiência regulamentadora da regionalização da saúde para o país como um todo” (Nascimento, 2007, p. 193).

Na NOAS, a regionalização e a organização de sistemas funcionais foram destacadas como elementos centrais para o avanço do processo de descentralização do SUS, em busca da eqüidade. Para tanto, cada estado deveria organizar seu território em Regiões de Saúde e Módulos Assistenciais. Na dependência do modelo de regionalização adotado, os estados seriam divididos em macrorregiões, regiões e/ou microrregiões de saúde. O Plano Diretor da Regionalização (PDR) foi proposto como o instrumento de ordenamento desse processo (Brasil.MS, 2002).

Os gestores enfrentaram muitas dificuldades para aplicação dessa norma, em decorrência da complexidade dos critérios técnicos estabelecidos, de difícil compreensão, implementação e acompanhamento. E, também, da ausência de mecanismos necessários para a negociação e pactuação de compromissos e responsabilidades entre os entes federados (Nascimento, 2007).

Em 2004, o MS assumiu a regionalização como prioridade desencadeando um processo de discussão junto à Comissão Intergestores Tripartite (CIT), com o objetivo de rever o processo normativo do SUS e buscar alternativas para enfrentar os impasses e dificuldades enfrentadas pelos gestores. Esses atores institucionais, assumindo a crítica aos instrumentos normativos utilizados até então, propuseram a construção de um pacto entre os gestores das três esferas de governo. Esse pacto deveria induzir uma inovação na gestão, qualificando-a para promover uma melhora 
do acesso aos serviços e da qualidade da atenção à saúde da população (Brasil.Conass, 2004; Silva e Dobashi, 2006).

O Pacto pela Saúde, aprovado pelo Conselho Nacional de Saúde, foi institucionalizado pela Portaria no 399 (Brasil.MS, 2006). Essa medida visava superar os mecanismos de habilitação de estados e municípios, contidos na NOB 01/96 e na NOAS SUS 2002. O Pacto propõe uma redefinição de responsabilidades coletivas, compartilhadas entre os gestores, centradas na necessidade de saúde da população, visando consolidar a descentralização do sistema na perspectiva da solidariedade, cooperação e autonomia dos entes federados (Silva e Dobashi, 2006).

A regionalização é um eixo estruturante desse novo instrumento de gestão do SUS que deve orientar tanto o processo de descentralização das ações e serviços, quanto à própria pactuação entre gestores. A estratégia proposta para operacionalizar e efetivar a regionalização está centrada na constituição de Regiões de Saúde, que podem assumir quatro formatos: intraestadual, intramunicipal, interestadual e fronteiriças.

O arranjo organizacional proposto para a estruturação dessas Regiões de Saúde foi a organização de redes de ações e serviços de saúde. A constituição de redes é apontada como uma estratégia de organização do sistema de saúde mais coerente com os princípios do SUS, superando o modelo clássico de sistema hierarquizado representado pela pirâmide de níveis de atenção com complexidade crescente (Cecílio, 1997; Misoczky, 2003; Silva e Mendes, 2004).

No entanto, Andrade e Santos (2008, p. 30) advertem que o Pacto pela Saúde “não está composto por elementos que sejam capazes de transformar a regionalização 
hoje existente em uma verdadeira rede de serviços de saúde, que integre todos os entes federados de uma dada região". Para esses autores, tanto os estados quanto a União “ainda se sentem e agem como entes com maior poder decisório”.

É importante considerar que a discussão e as propostas operacionais de regionalização do sistema de saúde sempre tiveram como foco principal a organização de sistemas regionais, articulando municípios para promover a integração de serviços de distintas densidades tecnológicas, visando a integralidade da atenção. Ainda existe pouca discussão sistematizada sobre experiências de regionalização intramunicipal, particularmente em municípios sede de regiões metropolitanas e capitais de estados, bem como sobre os desafios para o avanço desse processo.

Dessa forma, este artigo tem o objetivo de avaliar o processo de implantação de um projeto de organização de regiões de saúde no município de São Paulo, considerando seu potencial para promover a integralidade da assistência.

\section{MÉTODOS}

O percurso metodológico deste estudo foi fundamentado na pesquisa avaliativa, em sua dimensão da análise de implantação, centrada em um projeto de intervenção, considerando-se o contexto organizacional. Alguns modelos de análise adaptados da teoria das organizações podem ser utilizados para esse fim. Entre esses, utilizou-se o modelo político, no qual a implantação de uma intervenção é entendida como um jogo de poder organizacional. Dessa forma, o sucesso ou fracasso da implantação de 
um projeto é associado mais aos interesses dos distintos atores, ao cenário políticoinstitucional, do que ao seu planejamento (Denis e Champagne, 1997).

A partir desse referencial, optou-se pela estratégia de estudo de caso, que é caracterizado como uma investigação empírica de um fenômeno contemporâneo complexo inserido em algum contexto da vida real, especialmente quando os limites entre o fenômeno e o contexto não estão claramente definidos (Yin, 2005).

Foram utilizadas as seguintes fontes de evidência: entrevistas com informanteschaves, selecionados entre gestores da SMS-SP; documentos da gestão e atas ou memórias de reuniões. As entrevistas foram não-estruturadas, realizadas pelos próprios pesquisadores, gravadas e transcritas posteriormente. O entrevistado foi esclarecido sobre o tema central e, após uma explanação livre, o entrevistador solicitou o aprofundamento de alguns temas destacados na fala inicial.

A pesquisa abrangeu o período de uma gestão municipal da cidade de São Paulo (2005 a 2008), sendo que o trabalho de campo foi desenvolvido de 2006 a 2007. Considerando os objetivos do estudo, a dimensão territorial e populacional do município em questão, bem como sua complexidade, optou-se por delimitar este estudo a uma instância administrativa do nível regional da Secretaria Municipal de Saúde de São Paulo (SMS-SP). Sua eleição foi baseada nos seguintes critérios: a existência de um número significativo de serviços públicos de saúde dos distintos níveis de complexidade e, a manutenção da unidade político-administrativa do território desde a retomada do SUS no município. A escolha da região foi, posteriormente, negociada com assessores da SMS-SP. 
A região selecionada corresponde àquela sob a responsabilidade de uma Supervisão Técnica de Saúde (STS), abrangendo uma Subprefeitura com três Distritos Administrativos e com uma população residente estimada em cerca de 430 mil habitantes. Em termos populacionais, essa Subprefeitura é maior do que $96 \%$ dos municípios brasileiros (IBGE, 2001).

As STSs são instâncias subordinadas às Coordenadorias Regionais de Saúde (CRSs) e foram estruturadas segundo critérios populacionais, isto é, cada Supervisão deveria ser responsável por um território com cerca de 500 mil habitantes. A SMS-SP é composta por cinco CRSs e 24 STSs. Neste artigo, com o objetivo de preservar o anonimato dos entrevistados, utiliza-se a denominação de CRS-1 para identificar a Coordenadoria correspondente à STS selecionada. A CRS-1 é responsável por cinco STSs, abrangendo o território de sete Subprefeituras e uma população residente total estimada em cerca de 2,5 milhões de habitantes.

Mesmo com as mudanças ocorridas na estrutura político-administrativa da SMS-SP, o espaço territorial da STS selecionada corresponde àquele de estruturas regionais de gestões anteriores, desde o início do processo de implementação do SUS no município. Essa foi considerada uma variável importante de contexto, na medida em que tal situação poderia representar fator facilitador para a organização de uma região de saúde.

O material coletado foi analisado utilizando-se a técnica da análise temática (Bardin, 2004). A partir do trabalho de campo, realizou-se a classificação e agregação dos dados e a identificação dos temas, que permitiram uma melhor aproximação da realidade estudada: o projeto de organização de regiões de saúde e o processo de 
implementação do projeto de regiões de saúde. O projeto foi caracterizado a partir dos documentos de gestão da SMS-SP e da CRS-1, e das entrevistas. A construção da narrativa sobre o processo de implantação baseou-se em fatos ou relatos identificados em entrevistas e atas ou memórias de reuniões dos Fóruns da CRS-1.

O projeto de pesquisa, que gerou os dados utilizados neste artigo, foi aprovado pelos Comitês de Ética em Pesquisa da Faculdade de Saúde Pública da USP e da Secretaria Municipal de Saúde de São Paulo, com base na Resolução n ${ }^{\circ}$ 196/96 do Conselho Nacional de Saúde.

\section{RESULTADOS}

\section{Um projeto de organização de regiões de saúde}

Em 2005, no início de uma nova gestão, a SMS-SP realizou uma reforma administrativa, pautada na reestruturação e centralização do nível regional do SUS no município. Foram organizadas cinco novas CRSs a partir das Coordenadorias de Saúde pré-existentes, que foram reagrupadas e transferidas das Subprefeituras para a SMS-SP. Para dar funcionalidade às novas CRSs, foram criadas 24 STSs (São Paulo, 2005).

Constatou-se que o papel das CRSs ficou circunscrito à gestão dos serviços ambulatoriais próprios do município, não contemplando os demais serviços de saúde localizados em seu território. Manteve-se a separação político-administrativa entre atenção básica e a assistência hospitalar e de urgência e emergência. Essa permaneceu sob a gestão de cinco Autarquias Hospitalares que, posteriormente, 
foram transformadas em Coordenadorias Hospitalares Regionais (CHRs), subordinadas a uma Autarquia Hospitalar Municipal (São Paulo, 2008).

Embora, os limites territoriais das CRSs e das CRHs sejam coincidentes, esses se constituíram e se mantêm enquanto estruturas paralelas e independentes, observandose a persistência da dificuldade de articulação entre as mesmas.

"Então, [teve] todo esse movimento de criar coordenadoria, tirar da subprefeitura, de juntar...; mas não se conseguiu mexer na lei. Com isso não se conseguiu mexer na lei da autarquia, a autarquia continua como uma cisão" (coordenador regional 2).

Outra questão importante do contexto político-institucional da SMS-SP, observada durante o período da pesquisa, refere-se à significativa movimentação em seu quadro de direção. Na gestão 2005-2008, foram registradas três mudanças de secretários de saúde (quatro titulares) e, na região estudada, duas mudanças de coordenadores (três titulares) e quatro de supervisores (cinco titulares).

Paralelamente a essa reestruturação, foi proposta a divisão do município em 26 microrregiões. Para tanto, segundo relato do assessor técnico do gabinete da SMS-SP entrevistado, foi elaborado um diagnóstico de situação, utilizando os parâmetros da Portaria Nº 1.101 do Ministério da Saúde.

A necessidade de constituir um espaço regional para planejamento e organização do sistema de saúde nesse nível foi apresentada como uma das justificativas para o arranjo das microrregiões.

"Não tinha espaço onde os equipamentos, os responsáveis pelos serviços de saúde de determinada região sentassem juntos pra conversar. Inclusive, uma das propostas 
de organização foi se pensar em termos de acesso, não de divisão administrativa" (assessor técnico do gabinete da SMS-SP).

As microrregiões não seriam constituídas enquanto estruturas políticoadministrativas. A proposta previa a manutenção das CRSs e STSs e a definição de novos arranjos espaciais para as microrregiões, que não seguiam, necessariamente, a mesma divisão das STSs. Segundo o mesmo entrevistado, a microrregião não era para "ser uma estrutura formal. (...) Ela é funcional. É uma forma de você pensar na organização do sistema" (assessor técnico do gabinete da SMS-SP).

“A lógica é que tenha acesso à população. (...) De forma que toda microrregião tenha um hospital geral. (...) Eram microrregiões onde (...), até o nível secundário da atenção, (...) se pudesse resolver o próprio planejamento dessa programação, dos serviços ali daquela região" (assessor técnico do gabinete da SMS-SP).

Os relatos dos distintos gestores entrevistados evidenciaram que o hospital foi considerado o núcleo central, a partir do qual a microrregião seria organizada. " $A$ lógica seria a área de influência de um hospital” (coordenador regional 2).

“Inicialmente (...) foi realizada a divisão de áreas na região 1 e na secretaria como um todo, em microrregiões, onde a gente relacionava o hospital da região com os ambulatórios e as unidades básicas do entorno" (assistente técnico da CRS-1).

A organização de Fóruns foi a estratégia operacional assumida para a implementação das microrregiões, figurando entre as prioridades da CRS-1, definidas no início do governo. Identificou-se que esse tema foi abordado em dois documentos internos da gestão, elaborados pela equipe técnica dessa CRS: a) Diagnóstico Situacional da Coordenadoria Regional de Saúde 1 (CRS-1), que contém um diagnóstico regional 
propriamente dito e o Planejamento Plurianual (PPA 2006-2009) da região; b) Organização dos Fóruns de Planejamento e Regulação da Região 1.

De acordo com o documento intitulado Diagnóstico Situacional da CRS-1, em março de 2005, constituíram-se grupos específicos denominados Fóruns, que teriam a atribuição de identificar os nós críticos, elaborar e implementar projetos, objetivando o planejamento e organização do sistema de saúde regional. Estavam previstos um Fórum Regional, três Fóruns de Macrorregião (Ma) e um número não definido de Fóruns de Microrregião (Mi), representados graficamente na Figura 1. Estes seriam constituídos por distintos atores sociais, representantes das instituições e serviços que atuavam na região, desde gestores do nível central da SMS-SP e da SES-SP, gerentes dos serviços públicos, e as instituições privadas "parceiras" da SMS-SP na região.

"Qual que era a proposta da microrregião? Que a gente fizesse fóruns por microrregião e esses fóruns deviam incluir todos os prestadores da microrregião, sejam municipais, sejam estaduais, sejam não públicos” (coordenador regional 2).

No PPA 2006-2009 regional, organizado a partir de programas e, em consonância com o PPA 2006-2009 municipal, a organização e a continuidade dos distintos Fóruns foram destacadas entre as ações propostas para o programa "SUS com Qualidade”. Cabe ressaltar que o PPA contemplou, ainda, uma meta relacionada ao número de fóruns realizados, dentre os indicadores propostos para o monitoramento da gestão.

Já no documento Organização dos Fóruns de Planejamento e Regulação da Região 1, consta que os Fóruns deveriam acompanhar "desde o planejamento e a organização global do sistema de saúde regional até o acompanhamento e avaliação 
das ações no território de abrangência de cada unidade de saúde, permeando atenção básica, ambulatorial e hospitalar”. No entanto, a composição dos Fóruns apresentada nesse mesmo documento não previa a participação de todos os serviços de saúde localizados e/ou integrantes do sistema locorregional do SUS na região estudada. Tanto as unidades que concentram ações de atenção básica, quanto os ambulatórios de especialidades, participariam apenas dos Fóruns de Microrregião. E, os serviços privados conveniados não foram incorporados. Evidenciou-se assim, uma contradição nos dois documentos internos da CRS-1, entre os objetivos e a composição dos Fóruns, que excluía atores fundamentais para viabilizar o projeto.

\section{Os (des)caminhos do projeto de regiões de saúde}

Pode-se constatar que o projeto de implementação de regiões de saúde, apresentado acima, foi elaborado no nível central da SMS-SP e, posteriormente, apresentado aos níveis regionais para discussão. No decorrer do processo, a assessoria da SMS-SP buscou estabelecer um diálogo com dirigentes da Secretaria de Estado da Saúde (SES-SP) visando ampliar a governabilidade e viabilizar a operacionalização do projeto, na medida em que vários serviços especializados ainda se encontravam sob a gestão estadual.

“Estado e município, não conseguem ter uma visão do sistema como um todo e ver que o município é o gestor. Hoje, o município é gestão plena! (...) O estado até estava participando junto, eu já tinha conversado já com o [assessor técnico de coordenação da SES-SP-ATC]. O [coordenador da SES-SP] já tinha concordado, o [ATC] ia junto em algumas reuniões. (...) Era o recado do governo do estado para 
os serviços do estado que era para eles estarem sentando juntos" (assessor técnico do gabinete da SMS-SP).

A organização das microrregiões não ocorreu de modo uniforme em todo o município, “algumas coordenações desencadearam, outra não. (...) Na construção do processo, das propostas, algumas delas já foram levando em conta o resultado das reuniões, do processo" (assessor técnico do gabinete da SMS-SP).

É oportuno ressaltar que a CRS-1 foi coordenada, no início da administração municipal, pelo mesmo gestor que, posteriormente, assumiu o cargo de assessor técnico do gabinete da SMS-SP. Esse fato pode estar associado à implementação precoce do projeto nessa região, em um momento anterior à própria apresentação da proposta às demais regiões do município.

“A CRS-1 foi a primeira que saiu a frente nessa questão de fórum de micro porque a ... (assessor técnico do gabinete da SMS-SP) (...) tinha essa experiência do Estado, que (...) ela trouxe pra gente" (coordenador 1$)$.

A primeira reunião do Fórum Regional da CRS-1 foi realizada em março de 2005, logo no início da gestão municipal, período em que o ator em questão ocupava o cargo de coordenador regional. Essa reunião foi representativa, contando com a presença de 47 pessoas, representando distintas instâncias gestoras do SUS no município e serviços de saúde (Tabela 1). Nela, a coordenadora da CRS-1 apresentou a proposta de organização dos Fóruns, contemplando o objetivo e a composição dos Fóruns Regional e das Macrorregiões. Em relação aos Fóruns de Microrregiões, foi proposto que cada hospital geral estabelecesse sua área de abrangência e se reunisse com as Unidades Básicas de Saúde (UBS)s, os ambulatórios de especialidade, os 
serviços conveniados e os prestadores de serviço para realizarem ações integradas. $\mathrm{O}$ assessor de gabinete de SMS-SP presente sugeriu, ainda, a constituição de um "comitê deliberativo" com a atribuição de definir o que cada hospital deveria fazer, e ressaltou a importância do encontro e da conjuntura política, em que o mesmo partido político ocupava os governos do estado e do município de São Paulo.

Contudo, apesar dessa avaliação política favorável e da representatividade da reunião, a leitura da ata evidenciou que a discussão ficou limitada apenas ao relato das dificuldades enfrentadas no cotidiano dos serviços presentes. E, não foi possível identificar qualquer encaminhamento para as questões levantadas. Foram agendadas uma nova reunião desse Fórum e as primeiras dos Fóruns de Macrorregião.

A segunda reunião do Fórum Regional aconteceu três meses após a primeira, na data previamente agendada. No entanto, o número de participantes e a representatividade da reunião foram significativamente menores, marcada pela ausência de hospitais vinculados à SES-SP. De um total de oito hospitais previstos em sua composição, apenas dois compareceram (Tabela 1).

O Fórum da Macrorregião-1 realizou sua primeira reunião em maio de 2005, com a presença de 19 pessoas que representavam instituições ou serviços que atuavam nessa região (Tabela 1). Os presentes relataram dificuldades enfrentadas no cotidiano da gestão e algumas alternativas utilizadas para superá-las. Na ata dessa reunião, não foi registrada discussão e proposta de encaminhamento para essas questões. O próprio Fórum registrou e destacou a ausência de três, dos quatro hospitais estaduais componentes do mesmo e cujos serviços são essenciais para a organização de um sistema de referência regional. 
A segunda reunião desse Fórum foi realizada no mês seguinte, com um número menor de participantes, destacando-se a ausência não justificada de todos os hospitais vinculados à SES-SP, componentes do mesmo. O único hospital representado pertencia a outra macrorregião. Os participantes expuseram alguns problemas relativos à referência para os serviços de especialidade. Propôs-se a constituição de quatro microrregiões, a partir dos hospitais de referência.

A partir de junho de 2005, mês em que essa reunião foi realizada, não foram identificadas quaisquer outras reuniões, tanto do Fórum Regional, quanto da Macrorregião-1. As entrevistas com coordenador e um assistente técnico da CRS-1 corroboraram esse fato:

“(Os Fóruns) estão parados a partir desse mês de julho porque algumas coisas a gente não tinha governabilidade, a gente não, o grupo que tava participando" (coordenador 1).

"Por um ano a gente conseguiu manter minimamente essas reuniões de micro e de macro. Esse fórum maior, de macrorregião, a gente só teve em duas ocasiões. (...) Em julho de 2006 foi solicitado que a gente tentasse ter reuniões mais produtivas. E, chegou uma hora em que foi determinado: 'vamos dar um tempo', porque não estava caminhando em ganhos" (assistente técnico da CRS-1).

Nas atas disponibilizadas, não houve registro de qualquer reunião do Fórum da Microrregião-1, fato esse confirmado na entrevista com o supervisor da região. Cabe destacar que o hospital, a partir do qual seria organizada essa microrregião, esteve representado apenas na primeira reunião tanto do fórum regional quanto do macrorregional do qual era componente. 
“O hospital $X$, ele faz parte também da nossa microrregião, e existem aqui as reuniões de microrregião. E, eu estou aqui já desde dezembro, como eu falei, e até agora não foi agendada nenhuma reunião de micro” (supervisor).

Por outro lado, constatou-se a ocorrência de três reuniões do Fórum da Microrregião2, em meses consecutivos. Ressalte-se que o hospital localizado na Microrregião-1 é vinculado a SES-SP, enquanto o da Microrregião-2 é municipal. É importante destacar, ainda, que duas das quatro microrregiões propostas para a Macrorregião-1 seriam organizadas a partir de hospitais vinculados a SES-SP, uma a partir de hospital universitário e a outra de hospital próprio do município. De acordo com as atas, o único Fórum que se constituiu, de fato, foi aquele vinculado ao hospital municipal. Ao que parece, o envolvimento dos serviços nos Fóruns pode estar relacionado, entre outros fatores, com sua vinculação institucional.

A análise das atas permitiu identificar que ocorreu um significativo esvaziamento dos Fóruns como conseqüência, em grande medida, da não participação dos hospitais vinculados à SES-SP. Dentre os 13 hospitais sob gestão estadual constituintes do Fórum Regional, e presentes em sua primeira reunião, apenas dois compareceram à segunda.

Evidenciou-se, ainda que, apesar do objetivo manifesto ter sido a constituição de microrregiões, a estratégia adotada para implementação do projeto privilegiou os níveis regional e macrorregional. As microrregiões que seriam organizadas a partir desses espaços, não foram efetivamente implementadas.

Alguns atores entrevistados associaram a interrupção dos Fóruns à baixa governabilidade dos gestores regionais do SUS no município. Nesse sentido, é 
interessante observar a semelhança entre os relatos de dois gestores, entrevistados em separado e, em momentos distintos.

"Chegou um momento que a gente começou a perceber (...) que havia muitos fóruns de micro e as pessoas que desciam pra discutir no fórum não eram as pessoas que tinham governabilidade pra resolver nada. Então, você ia, ia, ia, falava, falava e não resolvia. Daí eu disse 'suspende qualquer reunião de micro agora, vamos tentar resolver esses nós que foram todos elencados, vamos discutir porque dependia da secretaria, dependia de situações de estado'. (...) Então essa governabilidade, a gente tem que levar pra secretaria essa discussão" (coordenador 1).

"Chegou uma hora que realmente travou o processo. Foi determinado que essas reuniões iam diminuir porque precisava ter minimamente uma autonomia maior. Mas, chegou uma hora em que não tinha essa autonomia mesmo, no sentido de aumentar os recursos, porque dependia da política geral, seja do município, seja do estado" (assistente técnico da CRS1).

As reflexões do assessor técnico do gabinete da SMS-SP, acerca das dificuldades enfrentadas para implementar esse projeto, incorporaram outros aspectos da política institucional para justificar a interrupção dos Fóruns.

"Eu acho que isso é assim uma coisa mais instituída. Faz parte da cultura. (...) O objetivo dos encontros era muito mais no sentido de pactuar os serviços. (...) Mudou o governo, mas as pessoas são as mesmas (...)você tem que mudar um pouco essa cultura e fazer, também, com que se enxergue que, na verdade, tem que ter um olhar da gestão, de fato, do sistema. (...) Cada um tem uma visão do que está acontecendo 
no sistema. Só que de uma forma fragmentada" (assessor técnico do gabinete da SMS-SP).

O insucesso do projeto foi relacionado, também, ao fato de que a SMS-SP não o assumiu enquanto uma de suas prioridades políticas. Segundo um dos coordenadores entrevistados o projeto, apesar de muito bom tecnicamente, ficou vinculado ao técnico que o idealizou, apesar de o mesmo ter ocupado cargo de confiança junto ao gabinete do secretário.

"Era um projeto do [assessor técnico do gabinete da SMS-SP]. Quando ele sai ninguém encabeça esse projeto de verdade, mas ele tinha muita consistência, do nosso ponto de vista dos coordenadores. (...) Não vou dizer que ela sumiu; ninguém disse pra mim 'olha esqueça o [projeto]' mas ninguém incentivou que aquilo andasse" (coordenador 2).

Considerando-se as questões e dificuldades registradas na implementação das microrregiões, foram levantadas hipóteses sobre fatores que podem ter condicionado a curta duração desse espaço potencial de gestão regional. Entre elas são destacadas as seguintes: a) a SMS-SP tinha baixa governabilidade para conduzir esse processo, na medida em que vários hospitais e ambulatórios de especialidades permaneciam sob a gestão da SES-SP; b) o nível regional (CRS) da SMS-SP, responsável pela coordenação do processo tinha pouca autonomia e baixa governabilidade, dado o caráter centralizador da gestão municipal; c) a construção do projeto não comprometeu todos os atores estratégicos para sua operacionalização; e) poder institucional dos hospitais e sua resistência em se integrar a um sistema de saúde. 


\section{DISCUSSÃO}

A concepção de região de saúde e as estratégias utilizadas para sua implementação, no município de São Paulo, refletem as orientações da política de saúde do período estudado, particularmente em relação ao modelo de atenção e ao caráter centralizador da gestão.

A prioridade conferida pela SMS-SP a esse projeto é outra variável que foi incorporada nessa análise. As constantes trocas de secretários municipais de saúde, observadas durante o período em estudo, podem indicar mudanças na orientação das políticas de saúde da SMS-SP, com repercussões nas suas prioridades. Assim, a viabilidade de um projeto apresentado no início da gestão, independentemente de sua qualidade técnica, tende a ser comprometida.

O hospital foi apresentado como o núcleo central da região de saúde, isto é, as microrregiões seriam organizadas a partir dos mesmos. A centralidade do hospital no modelo proposto ficou mais evidente a partir da análise da composição dos fóruns. Os serviços da atenção básica, os ambulatórios de especialidade e os prestadores privados da região estudada não foram integrados em qualquer etapa do projeto. Não se observou, tampouco, a preocupação de envolver representações de usuários e de trabalhadores da saúde nesse processo.

Por outro lado, não foi evidenciado processo de discussão e negociação prévia com os hospitais para que os mesmos assumissem o papel proposto. E, ainda, a implantação dos fóruns foi conduzida pela Coordenadoria Regional de Saúde que era 
responsável apenas pela assistência ambulatorial, não tendo relação institucional direta com os hospitais, os quais estavam subordinados a outra estrutura da SMS-SP. Essa situação era agravada pelo fato de que a SMS-SP não havia assumido a gestão dos ambulatórios de especialidade e hospitais estaduais, que continuavam sob a gestão da SES-SP. Esse quadro retrata a condição de baixa governabilidade do próprio gestor municipal em relação a esses serviços públicos de saúde localizados no município. Mesmo que a opção da SMS-SP fosse pelo compartilhamento ou cogestão do sistema com a SES-SP, as negociações ainda não haviam avançado nessa direção.

Deve-se ponderar, também, o papel desempenhado pelo gestor estadual nesse processo. Não se observaram evidências que demonstrassem o interesse da SES-SP em pactuar a gestão de seus serviços com a SMS-SP. Cabe observar que, no período estudado, o governo do estado implementou uma reestruturação daquela secretaria, reafirmando seu papel na gestão dos serviços ambulatoriais e hospitalares sediados na capital paulista. Nessa mesma direção, outros estudos (Oliveira, 2003; Solla, 2006) relataram a resistência do gestor estadual em implementar a gestão compartilhada ou a transferência de serviços para a esfera municipal, em particular em regiões onde o estado tinha maior tradição e estrutura de serviços de saúde, como é o caso do município de São Paulo.

Nesse cenário, o gestor regional do SUS municipal não teve, e dificilmente terá, governabilidade para coordenar a regionalização dos serviços de saúde, um processo complexo que demanda articulação e pactuação políticas entre distintos atores institucionais e sociais com interesses, por vezes, conflitantes. Na medida em que os 
atores presentes nessa arena política identificam a fragilidade desse gestor, mantémse a resistência às propostas de integração interinstitucional. É importante considerar que os distintos atores sociais, geralmente, ponderam e calculam sobre as vantagens, para sua posição, antes de aderir a qualquer projeto dessa magnitude (Matus, 1993; Coelho, 1998).

Outra questão importante a ser considerada na análise desse contexto está relacionada com a influência que políticas de saúde prévias e o desenho institucional exercem na conformação de uma determinada política de saúde (Hall e Taylor, 2003). Nesse sentido, destacam-se a trajetória e o lugar ocupado pelos hospitais no sistema de saúde brasileiro, na medida em que seu desenvolvimento foi marcado por um modelo que privilegiou a assistência médica hospitalar, com forte apoio do Estado. Ao mesmo tempo em que a instituição Hospital assumia grande centralidade no sistema de saúde, paradoxalmente, aumentava sua independência em relação ao mesmo. Cabe destacar, ainda, que os hospitais, inclusive os públicos, constituíram-se a partir de uma lógica organizacional específica, com um sistema próprio de normas e valores e desfrutam, até hoje, de uma considerável autonomia para estabelecer sua clientela e definir a modalidade assistencial ofertada (Campos, 1992; Carapinheiro, 1993).

O SUS, apesar de contemplar em seu projeto inicial críticas a esse modelo, foi implementado sobre a estrutura e lógica do extinto INAMPS (Instituto Nacional de Assistência Médica da Previdência Social), no qual o hospital era o núcleo central da assistência (Trevisan, 2007). No caso do município de São Paulo, é importante lembrar que grandes hospitais públicos, de hoje, foram construídos e instituídos pelos 
antigos IAPs (Institutos de Aposentadorias e Pensões), tendo sido incorporados pelo INAMPS e, posteriormente, pela SES-SP. Desde sempre funcionaram de forma autônoma e com muita resistência em se articularem com os demais serviços de saúde vinculados a SES-SP e, particularmente, a SMS-SP. Essa situação pouco se alterou, pois até 2008 os mesmos continuavam sob a gestão da SES-SP.

Considerando que a regionalização do sistema de saúde caminha pari passu à descentralização, é condição para sua operacionalização o fortalecimento da capacidade de governo e da governabilidade dos governos locais, particularmente em relação a setores que tradicionalmente não se submetiam ao controle da esfera municipal (Silva e Mendes, 2004; Lima, 2005). Quando esse processo ocorre internamente a um município, há que se considerar o papel estratégico que o gestor regional do SUS, no âmbito municipal, deve desempenhar em sua condução.

\section{Considerações Finais}

O projeto de regionalização proposto para o município de São Paulo apresentava uma racionalidade técnica coerente com os atuais desafios do SUS, na medida em que visava organizar sistemas de saúde funcionais, a partir de processos de pactuação e integração entre diferentes serviços existentes em uma região. No entanto, apesar de ter sido idealizado por assessores do Gabinete da SMS-SP, esse projeto não teve sustentação política, por não ter sido incorporado na agenda de prioridades da gestão municipal. Alguns elementos dessa política municipal de saúde eram, inclusive, muito desfavoráveis a um projeto dessa natureza. Dentre eles, destacam-se a centralização da gestão, com o esvaziamento técnico e político do nível regional, e a 
separação político-administrativa entre atenção básica e assistência hospitalar, agravada pela precária integração com os serviços sob a gestão da SES-SP.

No entanto, a despeito desses constrangimentos da política municipal de saúde, foi apresentado um projeto que teria grande potencial para construir um processo de regionalização mais funcional e racional, a partir do nível local. Porém, a operacionalização da proposta manteve a lógica formal centralizada da gestão. Por um lado, privilegiou o espaço macrorregional, mais estrutural, em detrimento ao microrregional, mais funcional. Na realidade estudada, as microrregiões não saíram do papel. Por outro lado, não envolveu todos os atores estratégicos para a constituição de uma região de saúde. Foram privilegiados os hospitais, que por sua história institucional e, pelo próprio contexto atual da saúde no município, não reconheciam a autoridade do gestor municipal para coordenar o processo. Assim, ao que nos pareceu, a estratégia utilizada para organizar espaços para pactuação e construção da regionalização não teve potência para envolver e sensibilizar os distintos atores.

\section{REFERÊNCIAS}

ABRUCIO, F.L. A coordenação federativa no Brasil: a experiência do período FHC e os desafios do governo Lula. Revista de Sociologia e Política. Curitiba, n.24, p.4167, jun. 2005.

ANDRADE, L.O.M.; SANTOS, L. Redes interfederativas de saúde e o SUS. Divulgação em Saúde para Debate. Rio de Janeiro, n.42, p.27-34, abril 2008.

ARRETCHE, M. Federalismo e Políticas Sociais no Brasil: problemas de coordenação e autonomia. São Paulo em Perspectiva, v.18, n.2, p.17-26, 2004.

BARDIN, L. Análise de Conteúdo. 3ª ed. Lisboa: Edições 70, 2004. 
BRASIL. Ministério da Saúde. Portaria n.373, de 27 de fevereiro de 2002. Norma Operacional da Assistência à Saúde - NOAS-SUS 01/02. Estabelece o processo de regionalização como estratégia de hierarquização dos serviços de saúde. Diário Oficial da União. Brasília, DF, 28 de fevereiro de 2002. Seção I, p.52.

BRASIL. Ministério da Saúde. Portaria n. 399, de 22 de fevereiro de 2006. Divulga o Pacto pela Saúde 2006 - Consolidação do SUS - e aprova as diretrizes operacionais do referido Pacto. Diário Oficial da União. Brasília, DF, 23 de fevereiro de 2006. Seção I, p.43.

BRASIL. Conselho Nacional de Secretários de Saúde (CONASS). Nota Técnica n.26/04. Pacto de Gestão. CONASS, 2004. Disponível em: http://www.conass.org.br/?page=publicacao notas\&ano=2004 Acesso em: 15 de agosto de 2008.

CAMPOS, G.W.S. Reforma da Reforma: repensando a saúde. São Paulo: Editora Hucitec, 1992.

CAMPOS, G.W.S. Reforma política e sanitária: a sustentabilidade do SUS em questão. Ciência \& Saúde Coletiva, Rio de Janeiro, v.12, n.2, p.307-317, março/abril 2007.

CARAPINHEIRO, G. Saberes e Poderes no Hospital: uma sociologia dos serviços hospitalares. $2^{\text {a }}$. ed. Porto: Edições Afrontamento, 1993. p. 17-43.

CECÍLIO, L.C.O. Modelos tecno-asistenciais em saúde: da pirâmide ao círculo, uma possibilidade a ser explorada. Cadernos de Saúde Pública. Rio de Janeiro, v.13. n.3, p.469-478, jul./set. 1997.

CECÍLIO, L.C.O et. al.. O gestor municipal na atual etapa de implantação do SUS: característica e desafios. Revista Eletrônica de Comunicação Informação \& Inovação em Saúde, v.1, n.2, p.200-207, 2007.

COELHO, V.S. Interesses e Instituições na Política de Saúde. Revista Brasileira de Ciências Sociais. São Paulo, v.13, n.37, p. 115-128, 1998.

DENIS, J.; CHAMPAGNE, F. Análise da Implantação. In: HARTZ, Z.M.A. (Org.). Avaliação em Saúde: dos modelos conceituais à prática na análise da implantação de programas. Rio de Janeiro: Fiocruz, 1997. p.49-88.

GERSCHMAN, S. A descentralização da política de saúde no final dos anos 1990. Revista de Administração Pública. Rio de Janeiro, v.34, n.4. p.147-70, jul/ago. 2000. 
HALL, P.A.; TAYLOR, R.C.R. As três versões do neo-institucionalismo. Lua Nova. São Paulo, n.58, p.193-223, 2003.

INSTITUTO BRASILEIRO DE GEOGRAFIA E ESTATÍSTICA - IBGE. Perfil dos Municípios Brasileiros: gestão pública 2001. Disponível em: http://www.ibge.gov.br. Acesso em: 15 de maio de 2008.

LIMA, L.L. Gestão da política de Saúde no Município: a Questão da Autonomia. 2005. Dissertação (Mestrado em Sociologia) - Universidade Federal do Rio Grande do Sul, Porto Alegre.

MATUS, C. Política, Planejamento \& Governo. Brasília: IPEA; tomo I, 1993. p.2962.

MENDES, E.V. Os grandes Dilemas do SUS. Salvador: Casa da Qualidade Editora, 2001 .

MENDES, E.V. O SUS que temos e o SUS que queremos. In: BRASIL. Conselho Nacional de Secretários de Saúde. Convergências e Divergências sobre a Gestão Regionalizada do SUS. Brasília: CONASS, 2004. p.28-61.

MISOCZKY, M.C. Redes e hierarquias: uma reflexão sobre arranjos de gestão na busca da eqüidade em saúde. Revista de Administração Pública. Rio de Janeiro, v. 37, n.2, p.335-54, mar./abr. 2003.

NASCIMENTO, V.B. SUS: Pacto Federativo e Gestão Pública. São Paulo/Santo André: Ed. Aderaldo\&Rothschild/Cesco, 2007.

OLIVEIRA M.H.C.B. Pactos de gestão: divisão de responsabilidades entre estados e municípios na descentralização. In: PIERANTONI, C.R., VIANNA, C.M.M. (Org). Gestão de Sistemas de Saúde. Rio de Janeiro: UERJ, IMS; 2003. p.59-92.

SÃO PAULO. Decreto n. 46.209. Dispõe sobre a transferência das Coordenadorias de Saúde das Subprefeituras que especifica para a Secretaria Municipal de Saúde. Diário Oficial do Município de São Paulo, 16 de agosto de 2005.

SÃO PAULO. Decreto n.49.331, de 19 de fevereiro de 2008. Regulamenta a lei n.14.669 no que se refere à organização e estruturação da Autarquia Hospitalar Municipal. Diário Oficial do Município de São Paulo, 20 fevereiro de 2008, folha 1. SILVA, M.V.C.P.; MENDES, E.V. Pacto de Gestão: da Municipalização Autárquica à Regionalização Cooperativa. Belo Horizonte: Secretaria de Estado de Saúde de Minas Gerais, 2004. 
SILVA, S.F.; DOBASHI, B.F. Um novo Pacto no SUS. Divulgação em Saúde para Debate. Rio de Janeiro, n.34, p.9-17, maio 2006.

SOLLA, J.J.S.P. Avanços e limites da descentralização no SUS e o "Pacto de Gestão”. Revista Baiana de Saúde Pública. Salvador, v.30, n.2, p. 332-48, jul/dez. 2006.

TOMBLIN, S. Ability to manage change through regionalization: theory versus practice. $2003 . \quad$ Disponível em: http://www.utas.edu.au/government/APSA/STomblinfinal.pdf. Acesso em: $5 / 11 / 2008$

TREVISAN, L. Das pressões às ousadias: o confronto entre a descentralização tutelada e a gestão em rede no SUS. Revista de Administração Pública. Rio de Janeiro, v.41, n.2, p.237-54, mar./abr. 2007.

YIN, R.K. Estudo de Caso: planejamento e métodos. $3 \square$ ed. Porto Alegre-RS: Bookman, 2005. 


\section{ANEXOS}

Figura 1. Esquema da organização das Regiões e Fóruns na CRS-1, SMS-SP

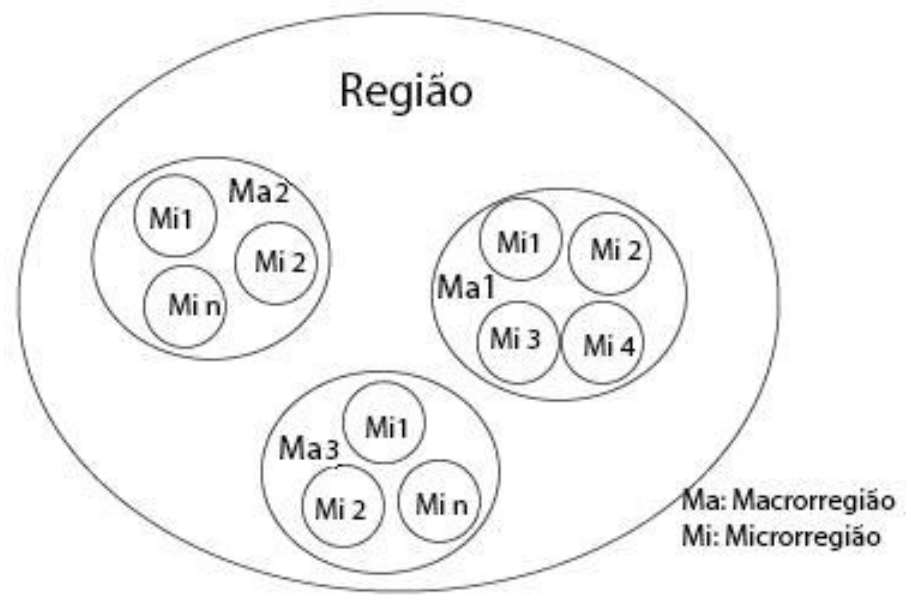

Tabela 1. Instituições e serviços participantes das reuniões do Fórum Regional e Fórum da Macrorregião-1 da CRS-1. São Paulo (SP), 2005.

\begin{tabular}{|c|c|c|c|c|c|c|c|c|}
\hline & & $\operatorname{Re}$ & onal & & & Macro & egião-1 & \\
\hline FÓRUM & $1^{\mathrm{a}} \mathrm{re}$ & Inião & $2^{\mathrm{a}} \mathrm{re}$ & Inião & $1^{\mathrm{a}} \mathrm{re}$ & Inião & $2^{\mathrm{a}} \mathrm{re}$ & Inião \\
\hline INSTITUIÇÃO & $\begin{array}{l}\text { particip } \\
\text { antes }\end{array}$ & $\begin{array}{l}\text { Institui } \\
\text { ções }\end{array}$ & $\begin{array}{l}\text { particip } \\
\text { antes }\end{array}$ & $\begin{array}{l}\text { institui } \\
\text { ções }\end{array}$ & $\begin{array}{l}\text { particip } \\
\text { antes }\end{array}$ & $\begin{array}{l}\text { institui } \\
\text { ções }\end{array}$ & $\begin{array}{l}\text { particip } \\
\text { antes }\end{array}$ & $\begin{array}{l}\text { institui } \\
\text { ções }\end{array}$ \\
\hline SMS-SP & 23 & 17 & 21 & 13 & 14 & 7 & 7 & 5 \\
\hline - Assessoria de Gabinete & 6 & 4 & 4 & 1 & 2 & 1 & 0 & 0 \\
\hline - Coordenadoria e Supervisões & 10 & 6 & 9 & 6 & 7 & 3 & 5 & 3 \\
\hline - Autarquia Hospitalar & 2 & 2 & 3 & 1 & 2 & 1 & 1 & 1 \\
\hline - Hospital e Pronto socorro & 5 & 5 & 5 & 5 & 3 & 2 & 1 & 1 \\
\hline - Ambulatório de Especialidades & 0 & 0 & 0 & 0 & 0 & 0 & 0 & 0 \\
\hline - UBS e PSF & & 0 & 0 & 0 & 0 & 0 & 0 & 0 \\
\hline SES-SP & 15 & 9 & 3 & 3 & 3 & 2 & 2 & 2 \\
\hline - Assessoria de Gabinete & 2 & 1 & 1 & 1 & 1 & 1 & 1 & 1 \\
\hline - Hospital & 13 & 8 & 2 & 2 & 2 & 1 & 1 & 1 \\
\hline - Ambulatório de Especialidades & 0 & 0 & 0 & 0 & 0 & 0 & 0 & 0 \\
\hline Outras & 9 & 3 & 2 & 2 & 2 & 2 & 0 & 0 \\
\hline - Hospital universitário & 1 & 1 & 1 & 1 & 1 & 1 & 0 & 0 \\
\hline - "Parceiro" privado de SMS-SP & 6 & 1 & 1 & 1 & 0 & 0 & 0 & 0 \\
\hline - Hospital privado prestador SUS & 0 & 0 & 0 & 0 & 0 & 0 & 0 & 0 \\
\hline - Outros & 2 & 1 & 0 & 0 & 1 & 1 & 0 & 0 \\
\hline TOTAL & 47 & 29 & 26 & 18 & 19 & 11 & 9 & 7 \\
\hline
\end{tabular}

Fonte: atas e memórias das reuniões da CRS-1 (2005) 


\subsection{O DIFÍCIL ACESSO A SERVIÇOS DE MÉDIA COMPLEXIDADE DO SUS NA MAIOR METRÓPOLE BRASILEIRA, SÃO PAULO (SP), BRASIL}

O artigo "O difícil acesso a serviços de média complexidade do SUS na maior metrópole brasileira, São Paulo (SP), Brasil” foi formatado para ser apresentado aos editores do periódico Physis de Saúde Coletiva, que é uma publicação do Instituto de Medicina Social, da Universidade Estadual do Rio de Janeiro, Rio de Janeiro (RJ). Foram seguidas todas as instruções, da revista, para elaboração de artigos.

Situação: Não enviado 
O difícil acesso a serviços de média complexidade do SUS na maior metrópole brasileira, São Paulo (SP), Brasil ${ }^{3}$

\section{The difficult access to secondary care services in the largest brazilian metropolis, São Paulo (SP), Brazil}

\section{Sandra Maria Spedo}

Médica Sanitarista - Depto. Medicina Preventiva, Unifesp. Mestre em Saúde Coletiva (Unicamp). Doutorando em Saúde Pública da Faculdade de Saúde Pública, USP.

Rua Botucatu, 740, CEP:04123-062, Vila Clementino - São Paulo (SP), Brasil

E-mail: smspedo@medprev.epm.br Tel.: (55-11)5571-50000 r.254

\section{Nicanor Rodrigues da Silva Pinto}

Médico Sanitarista - Depto. Medicina Preventiva, Unifesp; Mestre em Ciências da Saúde (Unifesp). Doutorando em Saúde Pública da Faculdade de Saúde Pública, USP.

Rua Botucatu, 740, CEP:04123-062, Vila Clementino - São Paulo (SP), Brasil

E-mail: nicanor@medprev.epm.br Tel.: (55-11) 5571-5000 r.254

\section{Oswaldo Yoshimi Tanaka}

Professor Titular - Departamento de Práticas - Faculdade de Saúde Pública, USP.

\footnotetext{
${ }^{3}$ A Pesquisa que originou os dados para realização deste artigo teve apoio financeiro parcial da FAPESP e CNPq.
} 


\section{RESUMO}

$\mathrm{O}$ acesso aos serviços de média complexidade tem sido apontado, por gestores e pesquisadores, como um dos entraves para a efetivação da integralidade do SUS. Este artigo teve o objetivo de avaliar mecanismos utilizados pela gestão do SUS, no município de São Paulo, para garantir acesso à assistência de média complexidade, durante o período de 2005 a 2008. Optou-se pela estratégia de estudo de caso, utilizando as seguintes fontes de dado: entrevistas com gestores; grupo focal com usuários e observação participante. Utilizou-as técnica de análise temática, a partir do referencial teórico da integralidade da assistência, na dimensão da organização de serviços. Buscou-se descrever os caminhos percorridos pelos usuários para acessar os serviços da média complexidade, a partir da visão dos gestores e dos próprios usuários. A média complexidade foi identificada, pelos gestores, como o "gargalo" do SUS e um dos principais obstáculos para a construção da integralidade. Para enfrentar essa situação o gestor municipal investiu na informatização dos serviços, como medida isolada e, ainda, sem considerar a necessidade dos usuários. Sendo assim, essa incorporação tecnológica teve pouco impacto na melhoria do acesso, o que se confirmou no relato dos usuários. Discute-se que para o enfrentamento de um problema tão complexo são necessárias ações articuladas, tanto no âmbito da política de saúde, quanto da organização dos serviços, bem como na (re)organização do processo de trabalho em todos os níveis do sistema de saúde.

Palavras-chave: média complexidade; integralidade; gestão em saúde; Sistema Único de Saúde; política de saúde. 


\section{ABSTRACT}

The population access to the secondary health care services is being pointed, by managers and researchers, as one of the challenges to the implementation of integrality in the Brazilian National Health System (SUS). This article has the objective of evaluate the mechanisms used by SUS manager's, in the city of São Paulo, to guarantee the medical assistance, during the period from 2005 to 2008. The strategy of case study was chosen, using as data sources such as managers interviews, focus groups with SUS users, and participative observation. Thematic analysis was made on health services organization, with theoretical references of the integrality concept. It tried to describe the path covered by the users to have access to the services, through the view of users and managers. The secondary health care services was identified by managers as the "neck of a bottle" and one of the main obstacle to the SUS integrality. To overcome this situation the municipal manager invested on the computerization of the services, as an isolated step, and still, without considering user's needs. Though necessary, this technological incorporation had low impact on the improvement of the population access to the secondary health care services, which was confirmed on user's sayings. It is argued that for such a complex problem are necessary articulated actions, not only on the health politics circuit but also on the organization of the services one, and also in the (re)organization of the working process in every level of the health system.

Key words: secondary health services; integrality; health management; Single Health System; health policy 


\section{INTRODUÇÃO}

O processo de construção do SUS é marcado por uma expressiva extensão da cobertura e do acesso dos cidadãos aos serviços de saúde. A partir de meados da década de 1990 houve um importante incremento de serviços de atenção básica (AB), induzidos pelo Ministério da Saúde por meio de critérios de habilitação dos municípios às distintas modalidades de gestão do sistema de saúde e de financiamento diferenciado, estabelecidos na NOB-SU96. A criação do piso de atenção básica (PAB) foi identificada por Bodstein (2002) como a principal estratégia do governo para operacionalizar a prioridade da AB. Esse se constituiu, ainda, em importante mecanismo de indução para viabilizar o Programa de Saúde da Família (PSF), apresentado como a estratégia para mudança do modelo de atenção.

Em 2006, o Ministério da Saúde reafirmou o papel estratégico da AB para a implementação do SUS. Essa deveria se consolidar enquanto porta de entrada preferencial e eixo orientador para estruturação dos sistemas locais de saúde. (Brasil.MS, 2007). Contudo, esse movimento de priorização da $\mathrm{AB}$, na última década, não foi acompanhado de investimento semelhante na organização dos demais níveis do sistema, bem como na articulação entre eles no sentido de garantir a continuidade do cuidado, visando à integralidade da atenção. Santos e Gerschman (2004, p. 803), ao analisarem a segmentação da oferta de serviços de saúde no Brasil, afirmam que "o SUS hoje parece estar caminhando no sentido do 'plano de cuidados básicos'” e abrindo mão da prestação direta de serviços de maior complexidade, que ficariam para a iniciativa privada. 
Nesse sentido, gestores de distintas esferas de governo têm assinalado que a dificuldade de acesso aos serviços especializados, ou à média complexidade, representa um dos principais entraves para garantir a integralidade da atenção. A presidente do Conselho de Secretários Municipais de Saúde do Estado de São Paulo (Cosems-SP), da época, apontou a existência de "um estrangulamento no acesso aos procedimentos de média complexidade. Isso afeta todos os municípios” (Pimenta, 2005). Em entrevista, o atual ministro da saúde também afirmou que a atenção especializada é "um desafio importante" para o SUS, na medida em que envolve questões complexas, relacionadas à qualidade dos serviços, à precarização dos salários, desorganização do sistema, falta de integração e articulação em vários níveis, e, ainda, sub-financiamento. "Se o ministério e seus parceiros não conseguirem dar respostas ao desafio da atenção ambulatorial e hospitalar das grandes cidades, eu teria fracassado" (Temporão, 2007, p. 12).

Esse problema foi identificado, também, em uma avaliação do processo de implementação do PSF em todos os municípios brasileiros, realizado pelo Ministério da Saúde, entre 2001 e 2002. Uma das conclusões apresentadas nessa avaliação foi que "o apoio diagnóstico e a referência para atenção especializada ainda foram insuficientes para garantir a resolubilidade e a continuidade da atenção às populações assistidas pelo Programa Saúde da Família”. E, a construção de redes assistenciais foi apontada como um dos principais desafios para garantir a continuidade da atenção, articulando atenção básica e serviços de média e alta complexidade (Brasil.MS, 2004, p. 24). Outros estudos, com abordagens distintas, contemplaram avaliações semelhantes ao considerar que a resolutividade da $\mathrm{AB}$ 
depende, em grande medida, do acesso a exames e serviços especializados (Teixeira, 2003; Mendes, 2007; Feuerwerker, 2005; Escorel e col., 2007).

Vale ressaltar que a resolubilidade da $\mathrm{AB}$ está associada a outros fatores, tais como, questões relacionadas à estrutura física dos serviços, processo e gestão do trabalho e capacitação dos profissionais que por sua vez, repercutem na demanda por serviços especializados. É importante considerar, ainda, o protagonismo dos usuários que, sob influência do modelo médico-hegemônico, pressionam e buscam serviços e procedimentos especializados.

Desde a década de 1920, distintos países vêm estruturando sistemas nacionais de saúde orientados pelas premissas apresentadas por Dawson, entre as quais se destaca a organização dos serviços em níveis de assistência (primário, secundário e terciário), com complexidade crescente (Novaes e Mir, 1990). No processo de implantação do SUS, foi introduzida nova terminologia para esses níveis de atenção, assumida, efetivamente, a partir da edição da NOAS SUS 01/2002. Partindo da mesma concepção hierárquica de sistemas de saúde, essa norma estabelece a regionalização como estratégia de hierarquização dos serviços de saúde, considerando para tal três níveis de atenção: atenção básica (AB), média complexidade (MC) e alta complexidade (AC). Atualmente, o Ministério da Saúde adota a seguinte conceituação (Brasil.MS, 2004):

Atenção básica: “constitui o primeiro nível de atenção. (...) Engloba um conjunto de ações, de caráter individual e coletivo, que envolvem a promoção da saúde, a prevenção de doenças, o diagnóstico, o tratamento e a reabilitação dos pacientes. 
(...) Cabe também à atenção básica proceder aos encaminhamentos dos usuários para os atendimentos de média e alta complexidade”.

Média complexidade: "Compõe-se por ações e serviços que visam atender aos principais problemas e agravos de saúde da população, cuja prática clínica demande a disponibilidade de profissionais especializados e o uso de recursos tecnológicos, para o apoio diagnóstico e terapêutico”.

Alta complexidade: "Conjunto de procedimentos que, no contexto do SUS, envolve alta tecnologia e alto custo, objetivando propiciar à população acesso a serviços qualificados, integrando-os aos demais níveis de atenção à saúde (atenção básica e de média complexidade)”.

Em decorrência da imprecisão conceitual, muitas vezes, define-se a MC por exclusão, ou seja, aquilo que "não cabe" na $\mathrm{AB}$ e que também não está na tabela da AC. Destaque-se, que esses conceitos denotam uma visão fragmentária de sistema e, ainda, centrada na produção de procedimentos (Brasil.Conass, 2007; Gottems e col., 2008).

A maioria dos procedimentos classificados, pelo Ministério da Saúde, na MC subsidia o esclarecimento do diagnóstico das doenças, o que justifica seu caráter estratégico tanto para aumentar a resolubilidade da $\mathrm{AB}$, quanto para viabilizar a universalidade e integralidade do SUS. A MC se constitui em "verdadeiro anteparo para o bom desempenho do sistema de saúde. Nesse sentido, tanto pode avançar na qualidade da atenção, como pode constituir-se em nó crítico dos mais complexos” (Gottems e col., 2008, p. 28-29). 
Dessa forma, o acesso aos serviços da MC se apresenta com um desafio para todos os gestores do SUS que, no entanto, assume diferentes dimensões, na dependência das características de cada estado, região, ou município.

O presente artigo teve como objetivo avaliar mecanismos utilizados pela gestão do SUS, no município de São Paulo, para garantir acesso à assistência de média complexidade e promover a integralidade da atenção.

\section{MÉTODOS}

Para a realização desta pesquisa, optou-se pela estratégia do estudo de caso que é caracterizado como uma investigação empírica sobre um fenômeno contemporâneo complexo, em seu contexto, especialmente quando os limites entre o fenômeno e o contexto não estão claramente definidos (Yin, 2005).

Considerando os objetivos do estudo, delimitou-se o campo a uma instância do nível regional da Secretaria Municipal de Saúde de São Paulo (SMS-SP). Essa corresponde a uma Supervisão Técnica de Saúde (STS) que abrange uma Subprefeitura com três Distritos Administrativos e com uma população residente estimada em cerca de 430 mil habitantes. No município, existem 24 STSs que são subordinadas a cinco Coordenadorias Regionais de Saúde (CRS)s. A CRS responsável por pela STS estudada contempla mais quatro STSs, abrangendo o território de sete Subprefeituras e uma população residente total estimada em cerca de 2,5 milhões de habitantes. 
A eleição do campo baseou-se nos seguintes critérios: a existência de um número significativo de serviços públicos de saúde dos distintos níveis de complexidade e, a manutenção da unidade político-administrativa do território desde a retomada do SUS no município. Essa escolha foi, posteriormente, negociada com assessoria da Secretaria Municipal de Saúde de São Paulo (SMS-SP)

O estudo abrangeu a gestão municipal da cidade de São Paulo do período 2005 a 2008, tendo sido utilizadas as seguintes fontes evidências: entrevistas com informantes-chaves, grupo focal com usuários de serviço de saúde, e observação participante.

As entrevistas foram de não-estruturadas, utilizando-se para tanto um roteiro básico com pontos considerados centrais, em torno dos quais os autores exploraram questões mais relevantes, o que permitiu detalhar temas de interesse. Essas foram conduzidas pelos pesquisadores, gravadas e, posteriormente, transcritas por um assistente de pesquisa. Foram entrevistados sete gestores da SMS-SP, tanto do nível locorregional quanto assessores do Gabinete, e um gestor da Secretaria de Estado da Saúde de São Paulo (SES-SP) - assessor técnico do Gabinete.

O grupo focal (Carlini-Cotrim, 1996) foi realizado com usuários de uma das Unidades Básicas de Saúde (UBS) da região estudada. O critério utilizado para seleção dos participantes foi ser portador de Hipertensão Arterial Sistêmica (HAS). Isso, por se tratar de uma doença crônica, de grande prevalência, que, por suas características, e critérios estabelecidos em programas institucionais, exige para seu acompanhamento exames e consultas especializadas. Buscaram-se junto à STS informações sobre cadastros de usuários portadores dessa patologia. Em decorrência 
da inexistência de registros, o caminho seguido foi identificar, entre as UBSs, aquela que mais encaminhava pacientes para consulta com cardiologista. A partir da definição da unidade, obteve-se a relação dos usuários encaminhados para cardiologia nos três meses anteriores. A partir da análise dos prontuários, foram selecionados e convidados 15 usuários. Desses, sete participaram do grupo. O tema explorado no grupo foi centrado nas facilidades e dificuldades enfrentadas pelos participantes para utilizar serviços de cardiologia.

A observação participante foi desenvolvida na UBS durante o processo de seleção e organização do grupo focal, em visitas a outros serviços de saúde, e em conversas com gestores e trabalhadores da região estudada.

A partir do trabalho de campo, realizou-se a classificação e agregação dos dados, tendo como referência a técnica da análise temática (Bardin, 2004). A categoria analítica central foi integralidade da atenção. Considerando a polissemia desse termo, assumimos utilizá-lo, neste estudo, em apenas um de seus múltiplos sentidos, qual seja, o modo de organizar os serviços e as práticas de saúde (Mattos, 2001) sem, contudo, desconsiderar, ou minimizar a importância dos demais. Giovanella e col. (2002) construíram um conceito de integralidade composto por quatro dimensões, sendo uma delas a garantia de atenção nos três níveis de complexidade da assistência médica. Para esses autores, essa dimensão está relacionada diretamente à organização do sistema de saúde.

O projeto de pesquisa, que gerou os dados utilizados neste artigo, foi aprovado pelos Comitês de Ética em Pesquisa da Faculdade de Saúde Pública da USP e da Secretaria 
Municipal de Saúde de São Paulo, com base na Resolução n 196/96 do Conselho Nacional de Saúde.

\section{RESULTADOS}

\section{O "gargalo" do SUS no município: a média complexidade}

O tema da média complexidade se destacou na análise das entrevistas, cujo objeto central foi a integralidade do SUS no município. Pode-se constatar um consenso entre os distintos relatos quanto à necessidade de superar os obstáculos no acesso à média complexidade para se avançar na integralidade do sistema.

Apesar da cidade São Paulo se constituir na maior e principal metrópole brasileira e, concentrar os principais serviços de assistência médico-hospitalar do país, a média complexidade foi avaliada, pelos gestores municipais, como o "gargalo", o "buraco", o grande "obstáculo" do SUS no município.

"No que se refere às consultas de urgência e emergência a impressão que a gente tem é que nós ofertamos mais do que o preconizado por qualquer parâmetro do Ministério. (...) No que se refere à consultas de complexidade primária, não é o suficiente pelo parâmetro do Ministério, mas também não é muito distante. No que se refere às consultas de média complexidade, aí tem um buraco, ai tem um déficit grande das consultas de média pra gente poder resolver. (...) O call center (...) distribui 100 mil consultas. (...)Mas o município precisa 300 mil ” (assistente técnico da SES -SP). 
“O gargalo é o nível secundário, o acesso de especialidades e exames pra diagnóstico. (...) Um gargalo que vira até obstáculo, é mais do que um desafio. Porque, uma coisa é um desafio que te motiva e você vai e tenta superar. Outra coisa é um obstáculo paredão que 'puxa daqui eu não consigo nem passar'. O que eu entendo como gargalo obstáculo é a parte da secundária (coordenador da atenção básica).

Os próprios gestores assinalaram alguns fatores que poderiam explicar, em parte, esse "buraco" na média complexidade. Um ponto que chama a atenção é o fato de que, em muitas situações, o acesso a procedimentos de alta complexidade é relativamente mais fácil do que a procedimentos da média complexidade.

“Até a alta complexidade você tem na cidade. Você consegue uma ressonância, você consegue até fazer um transplante hepático. Mas não consegue operar varizes! (...) Você pode dizer que é a vocação da cidade, a alta complexidade. Mas nós temos que ter alguma coisa também na média complexidade” (coordenador regional).

A Tabela SUS foi lembrada, por um dos gestores, como um dos fatores que estariam associados a essa situação. Isto, pois os valores pagos para procedimentos de alta complexidade são mais atrativos, o que induziria os prestadores privados a privilegiar a realização desses em detrimento daqueles da média complexidade.

“Um dos principais problemas da rede, em termos de acesso, nem é o da tomografia. É ultrassonografia. São os exames de média complexidade. (...) Normalmente [são feitos] nos hospitais, nos serviços contratados. (...) A tabela também não paga bem [os exames da média complexidade]. Então não é interessante pros conveniados contratados, sabe?" (assistente técnico do gabinete SMS-SP). 
A baixa resolutividade dos serviços foi destacada por vários gestores entrevistados. Por um lado, apontou-se a necessidade de qualificar os encaminhamentos da atenção básica por meio de capacitação dos profissionais, médicos em particular, e da elaboração e utilização de protocolos. No entanto, de acordo com os próprios entrevistados não houve nenhum avanço nessa direção.

"A gente tem que ter um pouquinho mais de protocolo. (...) Nós temos poucos, alguns protocolos, todos na gaveta. Operando na prática, muito pouco (...). Não conheço protocolos formais. Porque, protocolos que não são pactuados com o médico é um problema. Se ele não está convencido, ele não faz, não faz" (coordenador regional).

Por outro lado, foi abordada a baixa resolubilidade dos ambulatórios de especialidades. Essa foi associada tanto à má qualidade do atendimento, quanto à dificuldade em realizar os exames necessários para o esclarecimento do diagnóstico e/ou definição da terapêutica.

“Uma coisa que emperra é nossa capacidade de diagnóstico na especialidade. (...) Por exemplo, cardio. A quantidade de eco[cardiogramas] disponíveis, de eletro disponível é muito pequena. Então, o indivíduo fica tendo consulta no ambulatório de especialidade. Porque o tempo que ele leva pra conseguir consulta com cardio e firmar o diagnóstico e a conduta pra poder encaminhar também é grande. Porque nós temos um estreitamento da hora de conseguir os exames de especialidades" (coordenador da atenção básica).

Essa questão repercute no acesso de novos pacientes aos ambulatórios de especialidade, na medida em que aumenta o número de retornos até a resolução do 
caso. E, para agravar ainda mais essa situação, muitas vezes, por interesse do serviço, do médico ou até do próprio paciente, esse "congela no ambulatório" e não volta para a UBS. Sendo assim, “apesar do ambulatório de especialidades ter fechado vagas pras unidades (...) não quer dizer que eu passei na unidade eu vou conseguir agendar em tempo hábil e que o ambulatório está devolvendo rapidamente. Não está!" (coordenador da atenção básica). De acordo com o assistente técnico da SESSP, das 100 mil consultas de especialidade oferecidas mensalmente no call center apenas 20 mil são novas.

Vários gestores deram ênfase à condição particular das especialidades cirúrgicas, tais como ortopedia, urologia e cirurgia vascular, que apresentavam grande demanda reprimida. De acordo com seus relatos, a resolutividade dessas especialidades em ambulatórios isolados, sem retaguarda hospitalar é muito limitada.

"Passa no cirurgião vascular, ele fala: "não, realmente, tem varizes, tem que operar. Volta pra unidade básica. (...) Pra eles encaminharem pra um serviço que faz cirurgia vascular” (coordenador regulação CRS).

"O paciente é encaminhado ao ambulatório [X]. (...) Tem um fila de espera. Hoje, ortopedia tem aí 45 dias a 60 dias na fila esperando a consulta. Quando ele finalmente chega no dia abençoado da consulta, ao ser avaliado, o nosso ortopedista (...) avalia aquele caso, e aquele caso é cirúrgico. Faz um novo encaminhamento e a pessoa novamente entra na regulação como se fosse um caso novo (...) pra ser encaminhada pra um ambulatório que tenha cirurgia" (supervisor técnico).

Nesse sentido, dois gestores sugeriram que essas especialidades não deveriam ser mantidas em serviços ambulatoriais isolados, desvinculados de hospitais. O 
coordenador da regulação da SMS-SP questionou, inclusive, a ausência de um projeto político para enfrentar essa situação.

"Tem que ter uma política institucional pra que as coisas realmente aconteçam. Eu acho que você identifica esses vários problemas, organiza uma área e não adianta mesmo você ter o cirurgião naquele ambulatório sem que ele possa operar! (...) A gente nunca pode perder de vista essa linha de atenção, que é desde a porta de entrada até a resolução. Senão, a gente fica brincando o tempo todo, e o problema existe mesmo" (coordenadora regulação SMS-SP).

Alguns entrevistados deram destaque ao fato de que a SMS-SP não havia assumido, ainda, a gestão de todos os serviços públicos localizados no município. Essa conjuntura representava mais um importante entrave à organização do sistema de saúde, como pode ser evidenciado no trecho abaixo.

“(...) Essa diversidade de atores, que é um estado [Secretaria Estadual de Saúde] ainda muito forte na média complexidade, na alta complexidade. Então, você fica na dependência da política, dos humores da política. Onde pode, onde não pode. (...) Nós melhoramos muito, melhoramos muito na integração com o estado. Mas será sempre um grande desafio, visto que apesar da gestão plena a gente não tem a gestão de fato do serviço” (coordenador regional).

\section{Os caminhos para acessar a média complexidade: o relato dos gestores}

Pode-se constatar, neste estudo, que o acesso aos serviços da média complexidade, no município de São Paulo, estava condicionado ao encaminhamento dos usuários por uma UBS. Inclusive, os serviços de pronto-atendimento deveriam, 
obrigatoriamente, encaminhar os pacientes que necessitassem de consulta ou exame especializado para uma UBS, pois somente esse serviço tem acesso ao sistema de agendamento. Dessa forma, a SMS-SP transformou 'burocraticamente' a UBS na porta de entrada do SUS no município.

Essa medida tinha, pelo menos, duas repercussões importantes. A primeira, dificultar o acesso de pacientes que, de fato, necessitavam de serviços especializados. E, a segunda, de disputar e ocupar as poucas vagas disponíveis, para consultas médicas nas UBSs, com procedimentos meramente burocráticos, de "trocas de guia".

O sistema de regulação municipal é responsável por coordenar e organizar todo o fluxo de usuários no SUS municipal. Além de uma Coordenadoria no nível central da SMS-SP - Coordenadoria de Integração e Regulação do Sistema -, existiam equipes de regulação no âmbito das CRSs e das STSs. No entanto, evidenciou-se que a estrutura desse sistema no município era bastante limitada. "Até agora, a gente não tem tido nem perna nem vontade política de fazer realmente isso funcionar. (...) Nós somos poucas pessoas, as pessoas não são treinadas, não sabiam o que é regulação" (coordenador da regulação SMS-SP).

Essas limitações estruturais também foram ressaltadas pelos gestores da CRS e da STS.

“Eu tenho três pessoas trabalhando na regulação. (...) Essas pessoas, elas têm uma missão, um trabalho, muito grande, de regular o sistema de saúde onde você tem atores, (...) o estado (...) e uma parte mínima do sistema privado. (...) Eu não tenho uma estrutura administrativa, técnica. A regulação são pessoas" (supervisor técnico). 
“[A estrutura] é o grande gargalo. (...) Na coordenadoria é realmente uma coisa complicada. (...) Nós somos muito poucos” (coordenador regulação CRS).

Alegou-se que, em decorrência do número reduzido de técnicos que atuavam na área, tanto no nível central, quanto regional, não era possível desempenhar os distintos papéis do sistema de regulação. Os coordenadores da regulação demonstraram ter clareza quanto a suas atribuições. "A regulação no nível de coordenadoria deveria pensar mais, planejar, programar, organizar fluxo, organizar treinamento, verificar protocolos. A gente sabe que o ideal seria fazer isso. Só que hoje a gente está tomado pela falta de RH. (...) Então, ainda, a gente fica muito tempo assim, na coisa de agendamento, de não perder a consulta" (coordenador regulação CRS).

Além das limitações estruturais da própria SMS-SP, identificou-se outro entrave para a organização da regulação no município que estava relacionado à coexistência de dois sistemas, independentes, para marcação de consultas e exames de especialidades. Um, sob a gestão da SMS-SP (SIGA) que incluía os ambulatórios de especialidades vinculados ao município, alguns serviços privados sob seu comando, constituindo a denominada "agenda regulada". E, outro, sob a gestão da SES-SP (call center), que incorporava os ambulatórios e hospitais de especialidades vinculados à SES-SP, além de alguns serviços universitários e privados, contratados pelo estado.

O call center foi organizado pela SES-SP "como uma encomenda que os ambulatórios precisaram para resolver seu problema regional. Só que ele virou uma solução para o município de São Paulo” (assistente técnico da SES-SP). Ainda, segundo esse entrevistado "o ideal no futuro é o call center ser municipalizado, ai a prefeitura tem tudo isso na mão. (...) O que ocorre é que a prefeitura ainda não 
conseguiu assumir pra si essa função do call center, como assumiu a regulação da urgência e emergência”.

Os gestores municipais entrevistados relataram inúmeras dificuldades enfrentadas para realizar os agendamentos por meio do call center. A coordenação da regulação da SMS-SP reconhece a importância de integrar os sistemas, mas pondera que "o acesso é bom [com a SES-SP], a gente conversa, tem resposta, mas não vingou ainda. Assim, 'ah, agora nós vamos ter uma central única', por exemplo, imaginando que isso possa acontecer um dia. Mas aí, precisa realmente ter uma determinação de secretário pra secretário, pra fazer e aí institucionalizar. Isso ainda não aconteceu” (coordenador regulação SMS-SP).

A informatização dos serviços de saúde foi a estratégia assumida pela gestão municipal para organizar o fluxo do acesso para a média complexidade no município. A incorporação dessa tecnologia tornaria possível o agendamento de consultas e exames on line, a partir das UBSs. Esse era realizado, anteriormente, pela STS, sem a participação direta do usuário ou da própria UBS, o que acarretava dificuldades tanto para os usuários, quanto para o próprio sistema.

Houve concordância, na avaliação dos gestores, quanto ao impacto positivo dessa informatização. O agendamento realizado diretamente pela UBS, sem intermediários, na presença do usuário, representaria um importante avanço no sentido de facilitar o acesso dos mesmos aos serviços da média complexidade, reduzir o número de faltas nesses serviços e aperfeiçoar a organização do sistema de saúde no município. 
"Tem algumas coisas que são passíveis de melhora. Uma coisa importante que está conseguindo, está tendo a informatização das unidades. (...) Eu acho que isso vai facilitar, vai dar uma facilidade na integralidade” (coordenador da atenção básica).

Outro aspecto importante a ser destacado refere-se à lógica de distribuição das vagas. Anteriormente à informatização, as vagas eram distribuídas em cotas para as UBSs a partir de um "estoque" disponível para as CRSs, obedecendo a alguns critérios de regionalização. Logo no início do processo de informatização, por decisão da SMSSP esse mecanismo foi alterado. "A secretária de saúde disse que o desperdício era muito grande, que ela ia acabar com a cota e com a regionalização" (coordenador da regulação da CRS).

A partir dessa medida, as UBSs passaram a ter acesso à agenda de todos os serviços vinculados ao SUS no município, independentemente de sua localização geográfica. Com isso, em muitas situações o usuário da zona sul da cidade poderia ser encaminhado para atendimento na zona leste, mesmo havendo a disponibilidade do serviço próximo ao seu local de moradia, o que manteve o "desperdício". "Eles têm agendado muito. Só que o índice de faltas (...) tem sido muito grande. (...) O que a gente está vendo é que, de repente, vai se auto-regular nesse sentido, porque a unidade vai dizer assim: 'eu agendei o paciente lá pra ..., e o paciente não vai. Não adianta eu marcar mais lá” (coordenador da regulação da CRS).

O relato do coordenador da regulação do nível central também evidenciou que, na prática, a informatização não estava conseguindo resolver todos os problemas, conforme esperado. 
"Eu ouvi dizer que às vezes o sistema é tão lento que não dá para você marcar na hora como foi proposto. (...) Eu ouvi dizer (...) que tem unidade que não consegue acessar muito bem o sistema, que ele é muito devagar e acaba ainda agendando no papel e depois coloca no sistema e depois vai avisar o paciente. Quer dizer, funcionou na mesma!" (coordenador da regulação de SMS-SP).

\section{O caminho real: a vivência dos usuários}

A lógica de funcionamento do sistema vigente até então, desconsiderava completamente o usuário. $\mathrm{O}$ agendamento era realizado burocraticamente no dia, hora e local disponibilizados pelo sistema, sem qualquer diálogo com a necessidade e possibilidade dos interessados. Essa situação contribuía para aumentar ainda mais o número de usuários faltosos e, por conseqüência, a ociosidade dos serviços especializados. Segundo o assistente técnico da SES-SP, o índice de faltas nos serviços cujas vagas são disponibilizadas call center era de 40 a $60 \%$ para as primeiras consultas.

"Há um desperdício de um número grande de consultas. (...) Como o call center não dá a resposta imediata, o usuário é orientado a ir pra casa e voltar depois de um tempo pra saber quando foi agendada a consulta dele. Se ele não volta, essa consulta é reagendada e perdida. Muitas vezes procura-se levar até a casa dele, não consegue também. Outras vezes é marcada a consulta, mas é distante de tempo e

esquece. É impossível do ponto de vista prático pra ele. Ele mora na periferia da zona norte; se ele tiver que chegar às sete da manhã num ambulatório da zona sul. Não tem como chegar, impossível. Ele não sabe o caminho, ele vai ter que sair da 
casa dele três horas da manhã pra poder chegar às sete no ambulatório" (assistente técnico da SES-SP).

A discussão do grupo focal, realizado com usuários, no momento de transição para a informatização dos serviços, evidenciou que esses problemas ainda não haviam sido superados. É importante registrar que a discussão ficou centrada nos problemas, enfrentados pelos participantes do grupo, para acessar os serviços especializados. Esses eram tão significativos que se sobressaíram sobre os aspectos positivos, se é que eles existiam.

Embora o tema apresentado se referisse ao atendimento na área de cardiologia, no decorrer do grupo, foram agregadas informações sobre outras especialidades, o que possibilitou, em certa medida, uma visão mais abrangente sobre o acesso à média complexidade. Os temas centrais foram: as "regras do jogo" estabelecidas pelos serviços; a distância dos serviços especializados; a demora para conseguir atendimento.

Logo após a apresentação do tema aos participantes, a primeira manifestação foi de queixa sobre as "regras" de funcionamento e fluxo dos pacientes que são estabelecidas pelos serviços. Além de não serem previamente informados, em geral, os usuários se sentem prejudicados, pois as mesmas dificultam o acesso aos serviços.

Ficou evidenciado que parte dos presentes utilizava habitualmente o ambulatório de especialidades localizado na mesma região geográfica (Subprefeitura) em que se localizava a UBS, sendo de fácil acesso aos mesmos. Porém, por uma alegada falta de vagas e/ou médico cardiologista, esses usuários foram encaminhados de volta para a UBS de origem para, de lá, serem (re)encaminhados a outros serviços. 
“Eu tinha um cardiologista lá no [Ambulatório A]. (...) No dia que o cardiologista de lá saiu, não quiseram me dar outro”.

O ambulatório para o qual a UBS passou a encaminhar seus usuários era localizado em outra região da cidade de São Paulo. Para os participantes, a distância geográfica foi identificada como um obstáculo ao atendimento. "Agora eles manda lá pra esse fim de mundo, que eu nem sei [chegar]! (...) Pra esses quinto dos inferno, longe”.

A demora para conseguir o atendimento pretendido, seja realização de um exame ou consulta médica, foi o tema que assumiu maior relevância na discussão. Todos os participantes esperaram, ou ainda estavam esperando muito tempo para conseguir concretizar seu encaminhamento e, sem qualquer informação sobre o tempo provável de espera ou o local do atendimento. Um deles dizia estar há cerca de um ano esperando uma consulta com cardiologista para poder realizar cirurgia de catarata, que já estava agendada. Como não conseguiu, foi necessário reagendar a cirurgia.

Essa situação não se restringia à área de cardiologia. Foi lembrada, também, a demora para conseguir atendimento em outras áreas, em particular ortopedia.

"Eu to aqui também com um papel do ortopedista, que eu to com um problema no joelho. (...) E já vai pra seis meses e não me chama. Não sei o que está acontecendo”.

O longo tempo de espera não se limitava ao primeiro atendimento. Depois da longa espera para realizar o exame ou a consulta, em geral, enfrentava-se uma nova espera para retornar com o especialista.

"[O pedido de exame] foi em novembro de 2006. Depois fui chamado dia 14 de março. Vai fazer dois meses já. (...) Eu nem sabia que eles ia me ligar, eles me 
ligaram pra eu fazer o exame e eu fui. Só, como fiz a esteira lá, aí não tem vaga [para retorno], eu to na lista de espera. (...) Tá tudo envelopado, eu tenho que volta lá. (...) Porque só ele [o cardiologista] que tem que abrir o envelope”.

Muitas vezes, após a consulta, surgia um novo obstáculo a ser superado, como realizar exames subsidiários que não eram disponibilizados no ambulatório de especialidades. Sendo assim, o paciente necessitava retornar à UBS e, na dependência da dinâmica da unidade, entrar em uma nova fila para fazer o exame e aguardar o retorno do resultado, para então levá-lo ao especialista.

"Demorou quase uns seis meses pra essa vaga sair. (...) Aí eu fui lá ele pediu o exame de sangue: 'A senhora faz em qualquer posto. No retorno, a senhora me entrega aqui'. Eu vim aqui, conversei com a enfermeira. Ela autorizou, ela fez, depois eu vim pegar. (...) Eles marcaram a consulta lá, o retorno para dia 13 de agosto [daqui a três meses]. (...) E se eu tivesse alguma coisa?”.

Outra questão importante levantada foi que o longo tempo de espera para o atendimento, aliado à precária qualidade do mesmo, podia conduzir o usuário a buscar caminhos alternativos para resolver seus problemas, chegando inclusive a pagar por atendimento em serviços privados.

“Eu fui lá [no cardiologista], aí eu nem gostei da médica de lá. Ela me atendeu, ela nem mediu minha pressão. Aí ela pediu aquele exame lá de esteira. (...) Aí, marcou logo pra mim fazer o exame, né? Mas, pra mim ter retorno com ela de novo, só agora dia 20 de junho (...). Se não me encaminhar, então, eu vou pagar um cardiologista pra mim mostrar o exame”. 
Os usuários não tinham qualquer possibilidade de escolha, de decidir quando e onde gostariam de ir. Freqüentemente, aceitavam passivamente essa situação, pois relataram que quando solicitavam que o encaminhamento fosse feito para determinado local, mais próximo e de fácil acesso, ouviam dos trabalhadores da UBS que lá "não tem vaga”, e que iriam "encaminhar para onde tem vaga".

Um ponto que merece ser destacado sobre o perfil dos participantes do grupo, considerando o objetivo do estudo, é que todos utilizavam, preferencialmente, os serviços de saúde localizados na mesma região geográfica (Subprefeitura) em que

moravam. É importante lembrar que no território correspondente à STS, que inclui a UBS de origem dos mesmos, estão localizados três grandes ambulatórios de especialidades, dois hospitais especializados, todos públicos, e é exatamente para esses serviços que essas pessoas gostariam de ter sido encaminhadas.

\section{DISCUSSÃO}

A partir da aproximação que fizemos a uma das dimensões da organização do sistema de saúde no município de São Paulo, pudemos constatar que, apesar da existência de um grande número de serviços especializados em seu território, os gestores do SUS e seus usuários continuam enfrentando importantes obstáculos para acessá-los. Um município com tantos recursos, não deveria enfrentar, em tese, as mesmas dificuldades apresentadas por gestores de municípios de pequeno porte (Pimenta, 2005; Cecílio e col., 2007). 
A disponibilidade de recursos é uma das condições básicas para garantir o acesso dos cidadãos aos serviços de saúde. Deve-se considerar, contudo, que essa disponibilidade é apenas um dos fatores intervenientes no acesso. O acesso é um conceito complexo que apresenta múltipas determinações e varia de acordo com o contexto (Travassos e Martins, 2004). Nessa direção, Frenk (1999) diferencia acessibilidade de acesso a serviços de saúde e disponibilidade. Para esse autor a disponibilidade seria uma característica dos recursos de atenção à saúde, enquanto acesso é característica da população. Defende o conceito de acessibilidade que compreende a relação funcional entre a "resistência", ou obstáculos dos serviços, e o "poder de utilização" da população. Este último é concebido como o conjunto de características da população que dependem e refletem seu contexto de vida e que permitem à mesma buscar e obter atenção à saúde, superando os obstáculos.

Pode-se constatar que o poder de utilização dos usuários do SUS na realidade estudada não tem sido suficiente para ultrapassar a resistência dos serviços, o que mantém a condição de baixa acessibilidade. E, dada a dificuldade em modificar características da população, que interferem na utilização dos serviços de saúde, em curto prazo, reforça-se a necessidade de minimizar os obstáculos dos serviços para melhorar a acessibilidade dos cidadãos a todos os níveis de atenção à saúde no município, de forma a promover a integralidade.

É oportuno considerar, também, o papel que o modelo de atenção exerce na orientação da demanda aos serviços de saúde. Apesar dos avanços, o modelo que ainda prevalece hegemônico em nosso país é aquele centrado no médico, sob forte influência do complexo médico-industrial, que induz à demanda crescente e 
irracional de serviços com maior densidade tecnológica, tanto por parte dos profissionais de saúde, quanto pela própria população.

Nesta pesquisa foi possível identificar algumas ações que foram implementadas pela gestão municipal do SUS em São Paulo que, segundo o relato dos gestores, visavam minimizar o "obstáculo paredão" e viabilizar o acesso à média complexidade, no sentido de garantir a continuidade do cuidado.

A informatização do sistema foi assumida, pela gestão municipal, como a principal estratégia para enfrentar o "gargalo" do SUS no município. Essa era vista, a nosso ver, como uma panacéia, capaz de solucionar todos os problemas relacionados ao acesso de serviços especializados. Apesar da reconhecida importância da informatização para organização de serviços e fluxos, essa, certamente, não pode ser uma medida isolada. Houve uma supervalorização do potencial dessa tecnologia para enfrentar um problema complexo, com várias determinações.

Nesse sentido, merece destaque o fato de que a informatização não representou avanço no sentido de que o gestor municipal assumisse a gestão de todas as vagas disponibilizadas para o SUS. Ou seja, manteve-se um duplo sistema, agora informatizado, de agendamento e controle dos serviços de média complexidade, um sob gestão da SMS-SP e outro sob gestão da SES-SP. E, cabe ressaltar que a SES-SP ainda mantinha a gestão de parcela significativa de ambulatórios e hospitais de especialidade localizados no município.

Destacam-se que a organização e a informatização de complexos reguladores compõem o conjunto de ações propostas para implementar a regulação da atenção à saúde, na perspectiva da melhoria do acesso, da integralidade e da resolutividade do 
sistema de saúde. No Pacto de Gestão, um dos componentes do Pacto pela Saúde, a regulação do acesso à assistência ou regulação assistencial é conceituada como “conjunto de relações, saberes, tecnologias e ações que intermedeiam a demanda dos usuários por serviços de saúde e o acesso a estes” (Brasil. MS, 2006). Nesse sentido, a regulação do SUS é uma ação complexa que não se limita, assim, à informatização e implantação de centrais de internação, consultas e exames que visam, em muitas situações, apenas a adequação da demanda à oferta de serviços disponível.

A regulação envolve distintos atores (gestores, prestadores e usuários), com interesses, muitas vezes, conflitantes, implicando em relações políticas, técnicas e de cuidado. Trata-se, assim, de um conjunto complexo e articulado de ações que incorporam a condução política, a análise de situação e planejamento, com o objetivo de viabilizar o acesso do usuário aos serviços de saúde (Mendonça e col., 2006).

No entanto, no município de São Paulo, evidenciou-se que a implementação de ações de regulação se restringiu à estruturação de um complexo regulador com atuação centrada no controle de vagas para procedimentos especializados. A avaliação do coordenador da regulação é indicador da prioridade política e técnica conferida pela SMS-SP a essa área: "até agora, a gente não tem tido perna nem vontade política de fazer isso realmente funcionar".

Outro tema importante a ser incorporado nessa discussão refere-se à resolutividade da $\mathrm{AB}$. A relação entre a $\mathrm{AB}$ e a $\mathrm{MC}$ é um dos fatores condicionantes dessa resolutividade. Por um lado, a $\mathrm{AB}$ depende do acesso a procedimentos disponíveis na MC para aumentar sua resolutividade. Por outro, a baixa resolutividade da $\mathrm{AB}$ 
aumenta a demanda para a MC. Para enfrentar um problema dessa magnitude são necessárias mudanças organizacionais que combinem métodos de padronização, como protocolos, com transformações na prática da clínica (Campos, 2006). A estratégia para condução desse processo de mudança deve contemplar a constituição de espaços democráticos de pactuação entre os distintos atores envolvidos. Contudo, não foram identificadas iniciativas, por parte da SMS-SP, no sentido de reorganizar os processos de trabalho seja na $\mathrm{AB}$, seja nos ambulatórios de especialidade sob gestão municipal, apesar da concordância dos gestores quanto à baixa resolutividade desses serviços.

Um fato marcante, neste estudo, foi a desconsideração dos cidadãos/usuários enquanto sujeito e ator central do processo de construção do SUS em São Paulo. As longas filas de espera e a via crucis dos pacientes fazem parte do cotidiano da população usuária dos serviços públicos, há muito tempo. A gestão municipal continua desenvolvendo suas ações centradas nos interesses dos serviços e/ou corporações, desconsiderando as necessidades dos cidadãos/usuários.

Nesse sentido, constatou-se que algumas mudanças implementadas pela SMS-SP ocasionaram novos problemas para os usuários do SUS no município. Além da espera, eles passaram a enfrentar mais um obstáculo, a distância geográfica que teriam que percorrer para concretizar o atendimento. Essa situação foi agravada pela decisão da SMS-SP de "acabar com a regionalização". Na realidade estudada, a questão geográfica parece ter influência no acesso. Outros pesquisadores identificaram esse problema em distintas regiões do país (Silva e col., 1995; Oliveira, 2004). 


\section{Considerações finais}

Pode-se constatar que pouco se caminhou, no município de São Paulo, no sentido de alargar o "gargalo" da média complexidade e avançar na incorporação da universalidade e integralidade da atenção no SUS municipal. Ao que nos pareceu, esse tema não foi assumido como prioridade pela gestão municipal. Algumas ações foram implementadas na última gestão da SMS-SP, mas prevaleceu uma lógica racionalizadora em detrimento da necessidade do usuário.

É oportuno lembrar que a informatização do sistema de saúde já havia iniciado na gestão anterior e não visava apenas à organização do sistema de referência e contrareferência. E, ainda, a estruturação de sistemas regulatórios era condição, estabelecida pelo Ministério da Saúde, para a habilitação do município na gestão plena do sistema.

Por fim, é importante considerar que a média complexidade representa apenas um dos níveis do sistema de saúde, pontos de atenção de uma rede ou, ainda, parte dos recursos e serviços da linha de cuidado de uma atenção integral. Independentemente do arranjo organizacional de referência, julgamos que o enfrentamento desse problema exige grande investimento por parte do gestor do SUS. Para tanto, devemse implementar ações articuladas, tanto no âmbito da macropolítica, quanto da micropolítica, orientadas pelas necessidades de saúde dos cidadãos. A realidade observada no município de São Paulo ainda encontra-se bastante distante disso. 


\section{REFERÊNCIAS}

BARDIN, L. Análise de Conteúdo. 3ª ed. Lisboa: Edições 70, 2004.

BODSTEIN, R. Atenção Básica na agenda da saúde. Ciência e Saúde Coletiva. Rio de Janeiro, v.7, n.3, p.401-412, 2002.

BRASIL. Ministério da Saúde. Secretaria de Atenção à Saúde. Departamento de Atenção à Saúde. Avaliação Normativa do Programa de Saúde da Família no Brasil: monitoramento da implantação e funcionamento das equipes de saúde da família: 2001-2002. Ed. Ministério da Saúde. Secretaria de Atenção à Saúde. Brasília: Ministério da Saúde, 2004.

BRASIL. Ministério da Saúde. SUS de $A$ a $Z$ Z. Brasília:Ministério da Saúde/Conasems, 2004. Disponível em: http://dtr2004.saude.gov.br/susdeaz/ Acesso em: 20 de outubro de 2008.

BRASIL. Ministério da Saúde. Portaria n. 399, de 22 de fevereiro de 2006. Divulga o Pacto pela Saúde 2006 - Consolidação do SUS - e aprova as diretrizes operacionais do referido Pacto. Diário Oficial da União. Brasília, DF, 23 de fevereiro de 2006. Seção I, p.43.

BRASIL. Conselho Nacional de Secretários de Saúde. Assistência de Média e Alta Complexidade no SUS/Conselho Nacional de Secretários de Saúde. Brasília: CONASS, 2007.

BRASIL. Ministério da Saúde. Secretaria de Atenção à Saúde. Departamento de Atenção à Saúde. Política Nacional de Atenção Básica. 4a. Ed. Ministério da Saúde. Secretaria de Atenção à Saúde. Brasília: Ministério da Saúde, 2007.

CAMPOS, G.W.S. Clínica e saúde coletiva compartilhadas: teoria Paidéia e reformulação ampliada do trabalho em saúde. In: CAMPOS, G.W.S. et al. (Org.). Tratado de Saúde Coletiva. São Paulo: Hucitec; Rio de Janeiro: Fiocruz, 2006. p.5392.

CARLINI-COTRIM, Beatriz. Potencialidades da técnica qualitativa grupo focal em investigações sobre abuso de substâncias. Revista de Saúde Pública. São Paulo, v. 30, n. 3, p.285-293, 1996. 
CECÍLIO, L.C.O. et al. O gestor municipal na atual etapa de implantação do SUS: característica e desafios. Revista Eletrônica de Comunicação Informação \& Inovação em Saúde, v.1, n.2, p.200-207, 2007.

ESCOREL, S. et al. O programa de Saúde da Família e a construção de um novo modelo para atenção básica no Brasil. Revista Panamericana de Salud Publica, Washington - D.C., v.21, n.2/3, p.164-176, 2007.

FEUERWERKER, L. Modelos tecnoassistenciais, gestão e organização do trabalho em saúde: nada é indiferente no processo de luta para a consolidação do SUS. Interface - Comunicação, Saúde, Educação, Botucatu, v.9, n.18, p.489-506, set./dez 2005 .

FRENK, J. El concepto y la medición de acessibilidade. Salud Publica de Mexico, Cidade do México, v. 27, n. 5, 1985, p.438-453.

GIOVANELLA, L. et. al. Sistemas municipais de saúde e a diretriz da integralidade da atenção: critérios para avaliação. Saúde em Debate, Rio de Janeiro, v.26, n.60, p.37-61, 2002.

GOTTEMS, L.B.D et al. Relatório Final da Pesquisa: Análise da relação dos serviços de média complexidade com a rede básica do DF e entorno: buscando prioridades para ampliar acessos e resolubilidades. Universidade de Brasília, Universidade Católica de Brasília, Universidade Federal de Minas Gerais. Brasília, 2008.

MATTOS, R.A. Os sentidos da integralidade: algumas reflexões acerca de valores que merecem ser defendidos. In: PINHEIRO, R.; MATTOS, R.A. (Org.). Os sentidos da integralidade na atenção e no cuidado à saúde. Rio de Janeiro: UERJ, IMS/Abrasco, 2001. p.39-64.

MENDES, E.V. O SUS que temos e o SUS que queremos. In: BRASIL. Conselho Nacional de Secretários de Saúde. Assistência de Média e Alta Complexidade no SUS/Conselho Nacional de Secretários de Saúde. Brasília: CONASS, 2007. p.28-61. MENDONÇA, C.S.; REIS, A.T.; MORAES, J.C. (Orgs.) A Política de Regulação no Brasil. Brasília: OPAS/MS (Série técnica desenvolvimento de sistemas e serviços de saúde; 12), 2006.

NOVAES, H.M.; MIR, R.C. Sistemas locales de salude: um médio para la regionalización de los servicios de salude. In: PAGANINI, J.M.; MIR, R.C. (eds.) 
Los Sistemas Locales de Salud: conceptos, métodos, experiencias. Washington, D.C. (EUA): Organizacion Panamericana de la Salud (Publicación Cientifíca No. 519), 1990. p.147-158.

OLIVEIRA, E.X.G. et al. Acesso à internação hospitalar nos municípios brasileiros em 2000: territórios do Sistema Único de Saúde. Cadernos de Saúde Pública, Rio de Janeiro, v.20, supl. 2, p.S298-309, 2004.

PIMENTA, A.L. Presidente do Cosems afirma que prefeituras investem mais que Estados e União no financiamento do SUS. Jornal do Cremesp. Edição 215, 7/2005. Disponível em http://www.cremesp.com.br/?siteAcao=Jornal\&id=531. Acesso em: 25 de setembro de 2008 .

SANTOS, M.A.B.; GERSCHMAN, S. As segmentações da oferta de serviços de saúde no Brasil - arranjos institucionais, credores, pagadores e provedores. Ciência e Saúde Coletiva, Rio de Janeiro, v.9, n.3, p.795-806, 2004.

SILVA, L.M.V. et al. O processo de distritalização e a utilização dos serviços de saúde: avaliação do caso de Pau da Lima, Salvador, Bahia, Brasil. Cadernos de Saúde Pública, Rio de Janeiro, v.11, n.4, p.72-84, jan./mar 1995.

TEIXEIRA, C.F. A mudança do modelo de atenção à saúde no SUS: desatando nós, criando laços. Saúde em Debate, Rio de Janeiro, v.27, n.65, p.257-277, set./dez. 2003.

TEMPORÃO, J.G. (entrevista) Revista Conasems, ano II, n.23, p.5-12, maio/junho 2007. Disponível em http://www.conasems.org.br/files/revista23.pdf. Acesso em: 25 de setembro de 2008.

TRAVASSOS, C.; MARTINS, M. Uma revisão sobre os conceitos de acesso e utilização de serviços de saúde. Cadernos de Saúde Pública, Rio de Janeiro, v.20, suplemento 2, p.S190-S198, 2004.

YIN, R.K. Estudo de Caso: planejamento e métodos. $3^{\text {a }}$ ed. Porto Alegre: Bookman, 2005 . 
CONSIDERACCOES FINAIS 


\section{CONSIDERAÇÕES FINAIS}

A realização desta pesquisa representou um importante desafio, tanto em relação ao objeto estudado, quanto ao caminho metodológico escolhido. A partir da escolha do referencial teórico-metodológica, nosso foco foi direcionado para uma das inúmeras perspectivas possíveis para visualizar uma realidade complexa.

É importante ressaltar que a opção metodológica de utilizar a abordagem qualitativa permitiu a obtenção de dados, a partir das entrevistas com informantes-chaves, que não estão disponíveis em documentos. E, ainda, essa estratégia possibilitou conhecer e aprofundar as relações entre as distintas instâncias do SUS municipal.

O projeto de pesquisa, inicialmente, proposto previa uma relação dialógica com a equipe de gestão da Secretaria Municipal de Saúde de São Paulo. No entanto, o processo de negociação do mesmo e da entrada dos pesquisadores no campo permitiu identificar que a equipe de gestão municipal não tinha interesse pela pesquisa proposta. As resistências detectadas tiveram importante papel na readequação da proposta inicial às condições objetivas para sua realização.

Considerando os múltiplos sentidos do termo integralidade, no atual debate acadêmico e político da saúde pública brasileira, esse se apresenta como um tema de grande potencial para ser utilizado como uma categoria operativa ou um marcador para a avaliação de sistemas de saúde. No entanto, é importante reconhecer a necessidade de se estabelecer alguns parâmetros ou indicadores para a realização de pesquisas, em função da abrangência e dos significados desse princípio. Muitas 
diretrizes organizativas podem ser associadas ou interferirem na integralidade da atenção do SUS. Há uma relação de interdependência entre as distintas dimensões da integralidade e entre este e os demais princípios do SUS.

Embora, neste trabalho, tivéssemos utilizado um recorte ou um conceito operacional da integralidade, foram identificadas dificuldades para tanto. É importante reconhecer que a operacionalização desse princípio não ocorre com a mesma racionalidade com que se definem os enunciados teóricos.

A análise do contexto da política municipal de saúde forneceu elementos centrais para avaliar a incorporação da integralidade na organização dos serviços de saúde no nível locorregional do SUS, no município de São Paulo. Isso porque, em grande medida, alguns movimentos e prioridades da esfera da política de saúde condicionaram a organização e a gestão e, dessa forma, dificultaram a efetiva incorporação da integralidade da assistência no sistema. O principal produto da reestruturação implementada na SMS-SP foi uma forte (re)centralização da gestão municipal, com “enxugamento da máquina”, em particular do nível locorregional.

Paralelamente a esse processo, destacam-se outros dois movimentos da política de saúde implementada que contribuíram para consolidar antigas dicotomias prevenção versus cura, rede básica versus hospitais. A SMS-SP manteve a separação entre as estruturas político-administrativas responsáveis pela coordenação dos serviços ambulatoriais e pela coordenação hospitalar, consolidando dois subsistemas municipais sem espaços institucionais que propiciassem a integração entre elas. E, para agravar essa situação, foram mantidos serviços especializados estaduais ambulatoriais e hospitalares - sob a gestão de fato da SES-SP, o que configura a 
preservação de um terceiro subsistema de saúde atuando no município, com pouca integração entre eles.

Nesse sentido, o tema da centralização/descentralização da gestão do SUS no município de São Paulo se destacou com um dos principais fatores intervenientes para a efetivação da integralidade da atenção. A ênfase dada a essa questão provavelmente está associado às características particulares do município estudado, em que a Supervisão Técnica de Saúde estudada é responsável por uma população maior do que a de algumas capitais de estados brasileiros, como Florianópolis e Vitória, e equivalente a outras como as de Aracaju e Cuiabá. De forma análoga a essas capitais, não se pode esperar que uma Supervisão com essa dimensão e complexidade possa organizar a rede de serviços de saúde de seu território baseada apenas no protagonismo de gerentes de serviços, trabalhadores da saúde e usuários, sem qualquer estrutura político-administrativa formal.

Em que pesem os limites da descentralização da gestão, já discutidos por diversos pesquisadores, prevalecem os argumentos favoráveis a sua implementação em se tratando de políticas sociais e da saúde, em particular. Julgamos que esses mesmos argumentos se aplicam em relação à descentralização da gestão do SUS em uma metrópole como São Paulo. No entanto, com a centralização da gestão houve um concomitante esvaziamento técnico e político dos níveis regionais. Para viabilizar a implementação do sistema de saúde em um território com essa dimensão e complexidade, seguindo princípios e diretrizes de uma política pública de caráter nacional, é essencial, a nosso ver, garantir uma instância de gestão e uma equipe técnica no nível locorregional, com capacidade de gestão e governabilidade. Não foi 
isso que a pesquisa encontrou. Observou-se que política de saúde implementada pela SMS-SP produziu constrangimentos importantes para que o supervisor exercesse o papel de gestor de um sistema de saúde locorregional, apesar de seu protagonismo e potencial de ação. Na prática, esse dirigente tinha seu papel bastante limitado, de mero "fiscal" de serviços, como explicitado.

O contexto do SUS em São Paulo era desfavorável à implementação de um processo de regionalização, visando à articulação e integração entre serviços e estabelecimentos, organizados sob distintas lógicas e com interesses, por vezes, não convergentes. A baixa governabilidade da gestão locorregional aliada à resistência dos hospitais foram importantes condicionantes para inviabilizar a organização das microrregiões de saúde no município.

É importante reconhecer a existência de condicionantes históricos e institucionais atuando na conformação da lógica de funcionamento da instituição hospital que, embora responda a muitas necessidades da população, não dialoga com uma racionalidade sistêmica. Além disso, e nesse contexto municipal, tornou-se ainda mais difícil a integração dos hospitais com os demais serviços do sistema. $\mathrm{O}$ "gargalo" da média complexidade é, em parte, conseqüência dessa política institucional da SMS-SP.

A partir dessa pesquisa identificamos que o gargalo do SUS no município de São Paulo não se restringia à dificuldade de acesso à média complexidade. Constatamos que essa última gestão do SUS no município de São Paulo imprimiu uma direcionalidade à política de saúde que desconsidera a centralidade do usuário contribui para manter e aprofundar a fragmentação do sistema de saúde. Dessa forma 
o SUS em São Paulo continua distante da "imagem-objetivo" de um sistema de saúde que incorpore o princípio da integralidade como um de seus eixos estruturantes. 
REFERENCIAS 


\section{REFERÊNCIAS}

BARATA, L. R. B.; TANAKA, O. Y.; MENDES, J. D. V. 15 anos de SUS: desafios e perspectivas (2003). In: CONASS. Convergências e Divergências sobre Gestão e Regionalização do SUS. 2004. Disponível em: <http://dtr2001.saude.gov.br/dad/PactoGestao/docs>. Acesso em: 5 set. 2005. BARDIN, L. Análise de Conteúdo. 3a . ed. Lisboa: Edições 70, 2004. 229p. BRASIL. Lei n. ${ }^{\circ}$ 8.080, de 19 de setembro de 1990. Dispõe sobre as condições para a promoção, proteção e recuperação da saúde, a organização e o funcionamento dos serviços correspondentes e dá outras providências. Diário Oficial da União, Brasília, DF, 20 set. 1990. p. 018055.

BRASIL. Constituição. Constituição da República Federativa do Brasil (1988). Brasília, DF: Senado, 1988.

BRASIL. Ministério da Saúde. Portaria MS/GM no. 1.399, de 22 de julho de 2003. Habilita o município de São Paulo na condição de gestão plena de sistema municipal de saúde. Diário Oficial da União, Brasília, D.F, 23 de julho de 2003.

BRASIL. Ministério da Saúde. Portaria n. 399, de 22 de fevereiro de 2006. Divulga o Pacto pela Saúde 2006 - Consolidação do SUS - e aprova as diretrizes operacionais do referido Pacto. Diário Oficial da União. Brasília, DF, 23 de fevereiro de 2006. Seção I, p.43.

CAMARGO JÚNIOR, K. R. et. al. Avaliação da atenção básica pela ótica políticoinstitucional e da organização da atenção com ênfase na integralidade. Cadernos de Saúde Pública. Rio de Janeiro, v. 24, p. s58-s68, 2008. Suplemento 1.

CARLINI-COTRIM, Beatriz. Potencialidades da técnica qualitativa grupo focal em investigações sobre abuso de substâncias. Revista de Saúde Pública. São Paulo, v. 30, n. 3, p.285-293, 1996.

CARVALHO, M. R. Modelos assistenciais de unidades de saúde e integralidade. Estudo de caso: a área de planejamento 3.1 (RJ/RJ), contribuição para sua distritalização. 1991. 243 p. Dissertação (Mestrado em Saúde Pública) - Escola Nacional de Saúde Pública, Fiocruz, Rio de Janeiro. 
CECIM, R. B., FEUERWERKER, L. C. M. Mudança na graduação das profissões de saúde sob o eixo da integralidade. Cadernos de Saúde Pública. Rio de Janeiro, v. 20, n. 5, p. 1400-1410, 2004.

CECÍLIO, L. C. O. As necessidades de saúde como conceito estruturante na luta pela integralidade e eqüidade na atenção à saúde. In: PINHEIRO R., MATTOS R. A. (Org.) Os Sentidos da Integralidade na atenção e no cuidado à saúde. Rio de Janeiro: UERJ, IMS/Abrasco, 2001. p.113-126.

CONILL, E.M. Avaliação da integralidade: conferindo sentido para os pactos na programação de metas dos sistemas municipais de saúde. Cadernos de Saúde Pública. Rio de Janeiro, v. 20, n. 5, p. 1417-1423, 2004.

CONSELHO NACIONAL DE SAÚDE (CNS). Desenvolvimento do Sistema Único de Saúde no Brasil: avanços, desafios e reafirmação de princípios e diretrizes. Saúde em Debate, Rio de Janeiro, v.26, n.6, p.295-310, 2002.

DENIS, J. L.; CHAMPAGNE, F. A análise da implantação. In: HARTZ, Z. M. A. (Org.). Avaliação em Saúde: dos modelos conceituais à prática da implantação de programas. Rio de Janeiro: Ed. Fiocruz, 1997. p.49-120.

DESLANDES, S. F.; GOMES, R. A pesquisa qualitativa nos serviços de saúde: notas teóricas. In: BOSI, M. L. M.; MERCADO, F. J. (Org.). Pesquisa Qualitativa de Serviços de Saúde. Petrópolis: Vozes, 2004. p. 99-120.

FAVORETO, C. A. O. A narrativa na e sobre a Clínica de Atenção Primária: uma reflexão sobre o modo de pensar e agir dirigido pelo diálogo, à integralidade e ao cuidado em saúde. 2007. 220 p. Tese (Doutorado em Saúde Coletiva) - Instituto de Medicina Social, Universidade Estadual do Rio de Janeiro, Rio de Janeiro. FERREIRA, S. C. C. Aspectos da Integralidade do SUS: um estudo de caso na A.P.3.1 no município do Rio de Janeiro. 2003. Dissertação (Mestrado em Saúde Pública) - Escola Nacional de Saúde Pública, Fiocruz, Rio de Janeiro.

FURTADO, L. A. C. Distrito de Saúde e a Assistência Integral: o caso do Distrito de Saúde de Santana - São Paulo - 1989/1992. 1995. Dissertação (Mestrado em Saúde Pública) - Faculdade de Saúde Pública, Universidade de São Paulo. GIOVANELLA, L. et al. Sistemas municipais de saúde e a diretriz da integralidade da atenção: critérios para avaliação. Saúde em Debate. Rio de Janeiro, v. 26, n.60, p.37-61, 2002. 
GODOY, A. S. Pesquisa qualitativa: tipos fundamentais. Revista de Administração de Empresas. Rio de Janeiro, v.35, n.3, p.20-29, 1995.

HARTZ, Z. M. A.; CONTANDRIOPOULOS, A. P. Integralidade da atenção e integração de serviços de saúde: desafios para avaliar a implantação de um "sistema sem muros”. Cadernos de Saúde Pública. Rio de Janeiro, v. 20, p.S331-S336, 2004. Suplemento 2.

HONORATO, C. E. M. O trabalho político do profissional de saúde mental em um processo de desinstitucionalização: um estudo sobre integralidade e reforma psiquiátrica. 2007. 177 p. Dissertação (Mestrado em Saúde Coletiva) - Instituto de Medicina Social, Universidade Estadual do Rio de Janeiro, Rio de Janeiro.

KEHRIG, R. T. Integralidade da atenção à saúde: suas expressões na organização tecnológica do trabalho em serviços locais de saúde. 2001. 393 p. Tese (Doutorado em Saúde Pública) - Faculdade de Saúde Pública, Universidade de São Paulo, São Paulo.

LEVCOVITZ, E.; LIMA, L. D.; MACHADO, C. V. Política de saúde nos anos 90; relações intergovernamentais e o papel das Normas Operacionais Básicas. Ciência \& Saúde Coletiva, Rio de Janeiro, v.6, n.2, p.269-293, 2001.

LOPES, A. R. Diretrizes para o Planejamento de Serviços de Saúde Secundários e Terciários em Cardiopatia e Gravidez no Sistema Único de Saúde. 1996. Tese (Doutorado em Saúde Pública) - Faculdade de Saúde Pública, Universidade de São Paulo, São Paulo.

LOPES, C. G. Integralidade na saúde da mulher: a questão do climatério. 2007. 155 p. Dissertação (Mestrado em Saúde Pública) - Escola Nacional de Saúde Pública, Fiocruz, Rio de Janeiro.

MACHADO, M. F. A. S. et. al. Integralidade, formação, educação em saúde e as propostas do SUS: uma revisão conceitual. Ciência \& Saúde Coletiva, Rio de Janeiro, v.12, n.2, p.335-342, 2007.

MAEDA, S. T. Gestão de referência e contra referência na atenção ao ciclo gravídico puerperal: a realidade do Distrito de Saúde do Butantã. 2002. Tese (Doutorado em Saúde Pública) - Faculdade de Saúde Pública, Universidade de São Paulo, São Paulo. 
MATTOS, R, A. Os sentidos da Integralidade: algumas reflexões acerca de valores que merecem ser defendidos. In: PINHEIRO, R.; MATTOS, R. A. (Org.) Os Sentidos da Integralidade na Atenção e no Cuidado à Saúde. Rio de Janeiro: UERJ, IMS/Abrasco, 2001. p. 39 - 64.

MATTOS, R. A. A integralidade na prática (ou sobre a prática da integralidade). Cadernos de Saúde Pública, Rio de Janeiro, v.20, n.5, p.1411-1416, 2004. MATTOS, R. A. Direito, Necessidades de Saúde e Integralidade. In: PINHEIRO, R.; MATTOS, R. A. (Org.) Construção Social da Demanda: direito à saúde, trabalho em equipe, participação e espaços públicos. Rio de Janeiro: Cepesc/UERJ/Abrasco, 2005. p. 33-46.

MATTOS, D. As novas diretrizes curriculares e a integralidade em saúde: uma análise das possíveis contribuições da odontologia para o trabalho em equipe. 2006. 167 p. Dissertação (Mestrado em Saúde Coletiva) - Instituto de Medicina Social, Universidade Estadual do Rio de Janeiro, Rio de Janeiro.

MELLUCI, A. Por uma Sociologia reflexiva: pesquisa qualitativa e cultura. São Paulo: Vozes, 2005.

MENDES, E. V. O processo Social da Distritalização da saúde. In: (Org.).

O Distrito Sanitário. O processo social de mudança das práticas sanitárias do Sistema Único de Saúde. São Paulo-Rio de Janeiro: Hucitec/Abrasco, 1993. p. 93 158.

MINAYO, M. C. S. Fase de análise ou tratamento do material. In: . $\mathbf{O}$

Desafio do Conhecimento. Pesquisa Qualitativa em Saúde. $3^{\text {a }}$ ed. São Paulo/Rio de Janeiro: Hucitec/Abrasco, 1994. p. 197-247.

OLIVEIRA, A. G. R. C. A organização da demanda em serviços públicos de saúde bucal: uma contribuição ao estudo da universalidade, da eqüidade e da integralidade em Saúde Bucal Coletiva. 2000. 235 p. Tese (Doutorado em Odontologia) - Faculdade de Odontologia, Universidade Estadual Paulista, Araçatuba (SP).

OLIVEIRA, M. H. C. B. Pactos de Gestão: Divisão de Responsabilidade entre Estados e Municípios na descentralização. In: PIERANTONI, C; VIANNA, C. M. M. (Org.) Gestão de Sistemas de Saúde. Rio de Janeiro: Editora UERJ-Instituto de Medicina Social, 2003. p. 59-92 
OPS - Organizacion Panamericana de la Salud. Desarrollo y fortalecimiento de los Sistemas Locales de Salud em la transformacion de los Sistemas Nacionales de Salud. In: PAGANINI, J. M.; MIR, R. C. (ed.). Los Sistemas Locales de Salud: conceptos, métodos, experiências. Washington-DC: Organizacion Panamericana de la Salud (Publicación Científica No. 519), 1990.

PAIM, J. S. Atenção à Saúde no Brasil. In: Desafios para a Saúde Coletiva no Século XXI. Salvador: Editora da UFBA, 2006, p.11-47.

PINHEIRO, R. As Práticas do cotidiano na relação oferta e demanda dos serviços de saúde: um campo de estudo e construção da integralidade. In: ; MATTOS R. A. (Org.) Os Sentidos da Integralidade na Atenção e no Cuidado à Saúde. Rio de Janeiro: UERJ, IMS/Abrasco, 2001. p. 65- 12.

PINHEIRO, R.; FERLA, A.; SILVA JR., A. G. Integrality in the population's health care programs. Ciência \& Saúde Coletiva, Rio de Janeiro, v.12, n.2, p.343-349, 2007.

PIRES, V. M. M. Integralidade do cuidado no processo de trabalho das equipes de saúde da família: desafios na construção de uma prática de relações. 2007. 135 p. Mestre - Departamento de Saúde, Universidade Estadual de Feira de Santana, Feira de Santana (BA).

SÃO PAULO. SECRETARIA MUNICIPAL DE PLANEJAMENTO. Olhar São

Paulo - Contrastes Urbanos. Disponível em: ttp://sempla.prefeitura.sp.gov.br/olhar/. Acesso em: 12 nov. 2008.

SÁ, P. K. A integralidade da atenção no programa da família de Niterói/RJ. 2003. 115 p. Dissertação (Mestrado em Saúde Pública) - Escola Nacional de Saúde Pública, Fiocruz, Rio de Janeiro.

SAITO, R. X. S. Sistema Único de Saúde: da teoria à prática da integralidade. 2004. 145 p. Dissertação (Mestrado em Enfermagem) - Escola de Enfermagem, Universidade de São Paulo, São Paulo.

SANTOS, B. S. Um discurso sobre as ciências. São Paulo: Cortez, 2003. SERRA, C. G. Garantia de acesso à atenção básica e continuidade de cuidados como estratégias para consolidação da integralidade no SUS: uma análise sobre os processos de implantação do PSF, construção de sistemas de referência e regionalização assistencial no Estado do Rio de Janeiro. 2003. 204 p. Tese 
(Doutorado em Saúde Coletiva) - Instituto de Medicina Social, Universidade Estadual do Rio de Janeiro, Rio de Janeiro.

SILVA, J. P. V. Gestão compartilhada e construção da integralidade na atenção no SUS: a experiência da $4^{\mathrm{a}}$ Região Sanitária do Estado do Rio Grande do SUL período: 1999 a 2002. 2003. 128 p. Dissertação (Mestrado em Saúde Coletiva) Instituto de Medicina Social, Universidade Estadual do Rio de Janeiro, Rio de Janeiro.

SILVA, V. C. O Processo de Implantação do Sistema Integrado de Serviços de Saúde em Vitória - ES: contribuição à discussão da integralidade na atenção à saúde. 2004. Dissertação (Mestrado em Saúde Pública) - Escola Nacional de Saúde Pública, Fiocruz, Rio de Janeiro.

SILVA, S. F.; DOBASHI, B. F. Um novo Pacto no SUS. Divulgação em Saúde para Debate. Rio de Janeiro, n.34, p.9-17, maio 2006.

SILVA, T. C. S. A construção das práticas de integralidade no cotidiano de uma equipe de saúde da família. 2006. 141 p. Dissertação (Mestrado em Enfermagem) Faculdade de Enfermagem, Universidade Federal de Minas Gerais, Belo Horizonte.

SILVA, K. L.; SENA, R. R. Integralidade do cuidado na saúde: indicações a partir da formação do enfermeiro. Revista da Escola de Enfermagem da USP. São Paulo. v. 42, n. 1, p.48-56, 2008.

TANAKA, O. Y. (coord.), PINTO, N. R. S.; SPEDO, S. M. O processo de (re)construção do Sistema Único de Saúde no município de São Paulo. Uma avaliação sobre a incorporação do princípio da integralidade na política municipal de saúde. São Paulo, FSP-USP, Jun 2005. [mimeo] VIANA, A. L. A. et al. Descentralização no SUS: efeitos da NOB-SUS 01/96. In: NEGRI, B.; VIANA, A.L.A. (Orgs.). O Sistema Único de Saúde em dez anos de desafio. São Paulo: Sobravime/Cealag, 2002. p. 471-488.

YIN, R. K. Estudo de Caso: planejamento e métodos. 3ª ed. Porto Alegre: Bookman, 2005. 